\title{
200-BP-1 Prototype Hanford Barrier - 15 Years of Performance Monitoring
}
AL Ward
KE Draper
SO Link
RE Clayton

September 2009

Pacific Northwest

NATIONAL LABORATORY

Proudly Operated by Battelle Since 1965 


\title{
DISCLAIMER
}

This report was prepared as an account of work sponsored by an agency of the United States Government. Neither the United States Government nor any agency thereof, nor Battelle Memorial Institute, nor any of their employees, makes any warranty, express or implied, or assumes any legal liability or responsibility for the accuracy, completeness, or usefulness of any information, apparatus, product, or process diselosed, or represents that its use would not infringe privately owned rights. Reference herein to any specific commercial product, process, or service by trade name, trademark, manufacturer, or otherwise does not necessarily constitute or imply its endorsement, recommendation, or favoring by the United States Government or any agency thereof, or Battelle Memorial Institute. The views and opinions of authors expressed herein do not necessarily state or reflect those of the United States Government or any agency thereof.

\author{
PACIFIC NORTHWEST NATIONAL LABORATORY \\ operated by \\ BATTELLE \\ for the \\ UNITED STATES DEPARTMENT OF ENERGY
}

under Contract DE-AC05-76RL01830

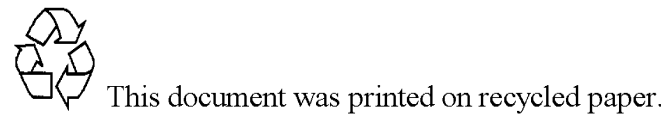

$(9 / 2003)$ 


\section{0-BP-1 Prototype Hanford Barrier - 15 Years of Performance Monitoring}
AL Ward
KE Draper
SO Link
RE Clayton

September 2009

Prepared for

the U.S. Department of Energy

under Contract DE-AC05-76RL01830

Pacific Northwest National Laboratory

Richland, Washington 99352 



\section{Summary}

Engineered surface barriers are recognized as a remedial alternative to the removal, treatment and disposal of near-surface contaminants at a variety of waste sites within the DOE complex. One issue impacting their acceptance by stakeholders the use of limited data to predict long-term performance. In 1994, a 2-ha multi-component barrier was constructed over an existing waste disposal site at Hanford using natural materials. Monitoring has been almost continuous for the last $15 \mathrm{yrs}$ and has focused on barrier stability, vegetative cover, plant and animal intrusion, and the components of the water balance, including precipitation, runoff, storage, drainage, and percolation. The total precipitation received from October 1994 through August 2008 was $3311 \mathrm{~mm}$ on the northern half (formerly irrigated), and $2638 \mathrm{~mm}$ on the southern, non-irrigated half. Water storage in the fine-soil layer shows a cyclic pattern, increasing in the winter and decreasing in the spring and summer to a lower limit of around $100 \mathrm{~mm}$, regardless of precipitation, in response to evapotranspiration. Topographic surveys show the barrier and side slopes to be stable and the pea-gravel admix has proven effective in minimizing erosion through the creation of a desert pavement during deflationary periods. Three runoff events have been observed but the $600-\mathrm{mm}$ design storage capacity has never been exceeded. Total percolation ranged from near zero amounts under the soil-covered plots to over $600 \mathrm{~mm}$ under the side slopes. The asphaltic concrete prevented any of this water from reaching the buried waste thereby eliminating the driving force for the contaminant remobilization. Plant surveys show a relatively high coverage of native plants still persists after the initial revegetation although the number of species decreased from 35 in 1994 to 10 in 2009. Ample evidence of insect and small mammal use suggests that the barrier is behaving like a recovering ecosystem. In September 2008, the north half of the barrier was burned to remove vegetation and study the effects of fire on barrier performance. The most immediate effects has been on water storage patterns with the bare surface showing a slower accumulation of water, a smaller peak storage and a delayed release relative to the unburned side due to evaporation. Nonetheless the residual storage at the end of the year was similar for the burned and unburned sides. 



\section{Contents}

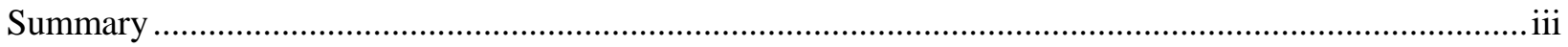

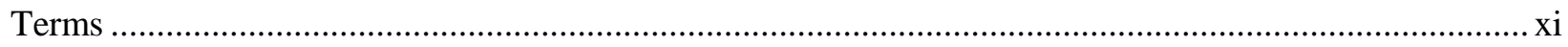

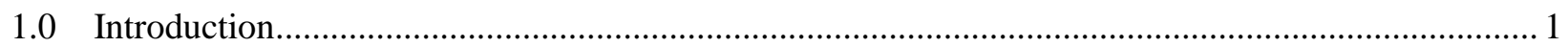

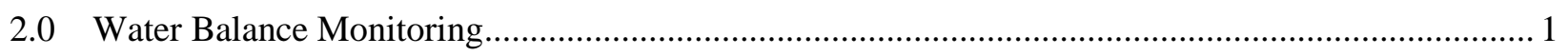

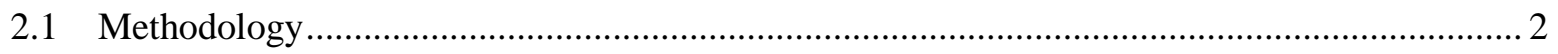

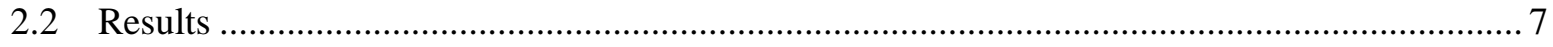

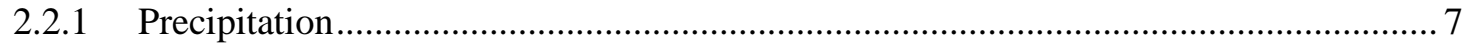

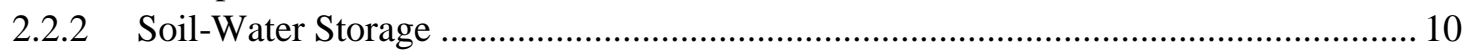

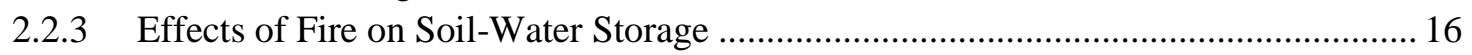

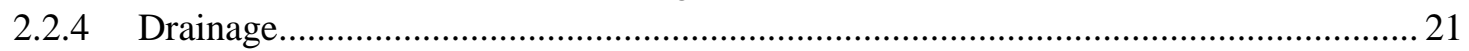

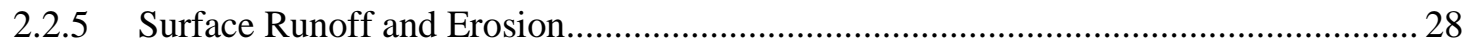

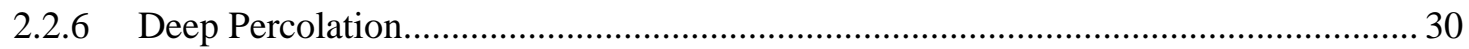

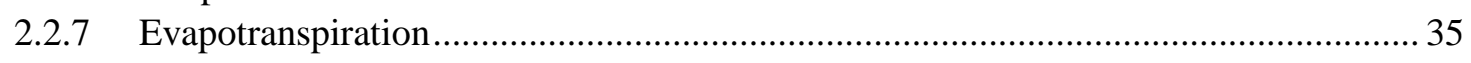

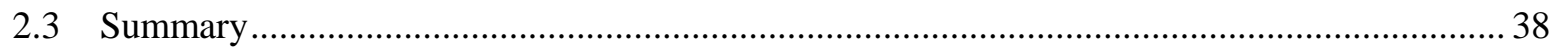

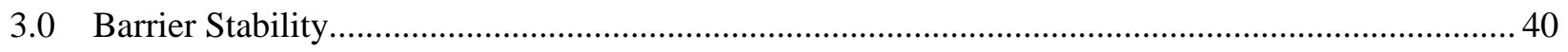

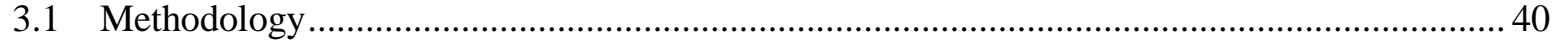

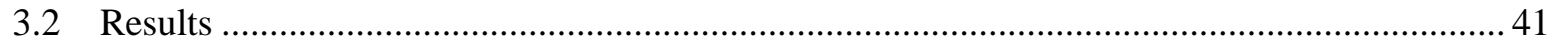

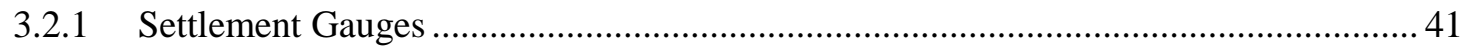

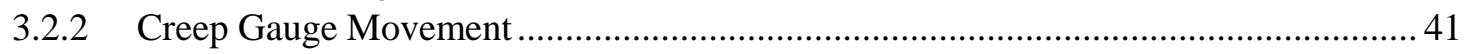

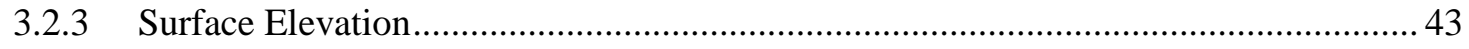

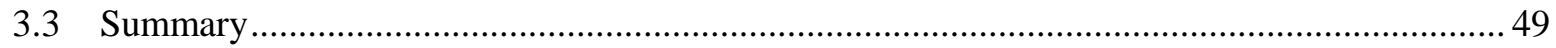

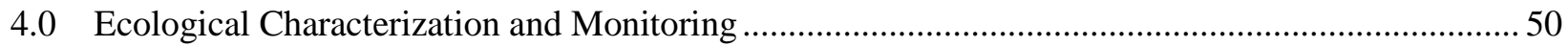

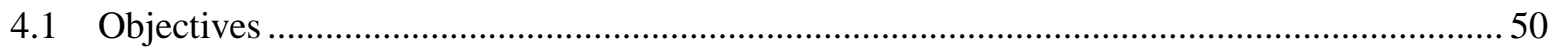

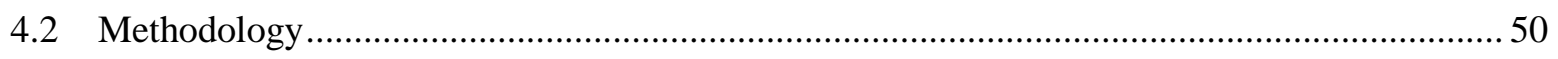

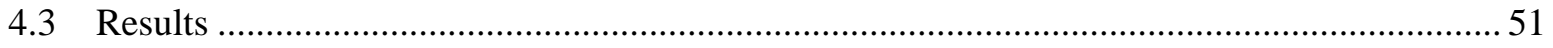

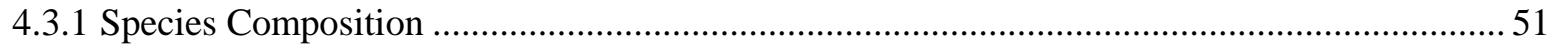

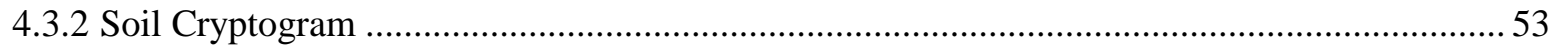

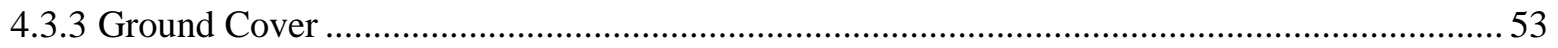

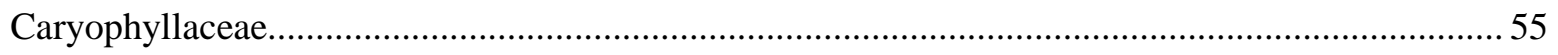

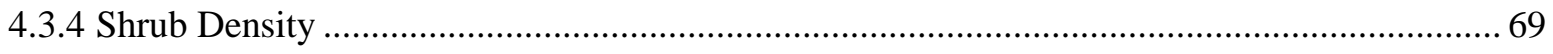

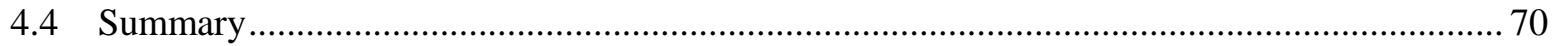




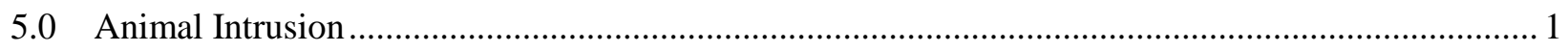

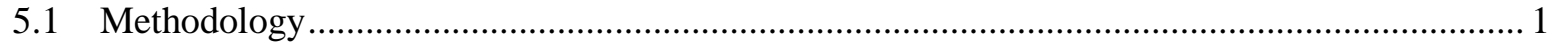

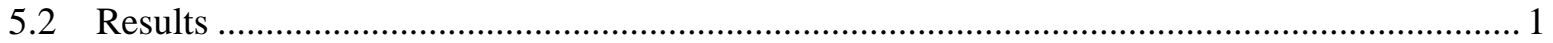

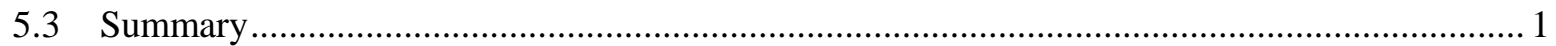

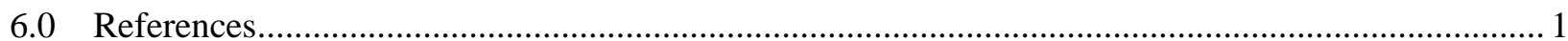




\section{Figures}

2.1. Plan View of the Prototype Hanford Barrier Showing Monitoring Stations

2.2. Plan View of the Prototype Hanford Barrier Showing the Layout of the 12 Surface Soil Plots (1W to 6W and 1E to 6E) and Horizontal Neutron Access Tubes (AA Above Asphalt; BA Below Asphalt)

2.3. Natural and Total Precipitation (Natural plus Irrigation) at the Prototype Hanford Barrier From October 1, 1994, September 30, 2009.

2.4. Temporal Variation in Soil-Water Storage in Northwest Plot $6 \mathrm{~W}$ at the Prototype Hanford Barrier, October 1994 Through September 2009 (design water storage capacity is $600 \mathrm{~mm}$ )

2.5. Temporal Variation in Soil-Water Storage in Northwest Plot $6 \mathrm{E}$ at the Prototype Hanford Barrier, October 1994 Through September 2009 (design water storage capacity is $600 \mathrm{~mm}$ )........ 12

2.6. Temporal Variation in Soil-Water Storage in Northwest Plot $3 \mathrm{~W}$ at the Prototype Hanford Barrier, October 1994 Through September 2009 (design water storage capacity is $600 \mathrm{~mm}$ )........ 14

2.7. Temporal Variation in Soil-Water Storage in Northwest Plot 3E at the Prototype Hanford Barrier, October 1994 Through September 2009 (design water storage capacity is $600 \mathrm{~mm}$ )........ 15

2.8. Temporal Variation in Mean Soil-Water Storage on the North and South Plots at the Prototype Hanford Barrier, October 1994 Through September 2009 (design water storage capacity is $600 \mathrm{~mm}$ ).

2.9. Vertical Profiles of Water Content Measured at the Barrier Before and After the September 26, 2008 Fire.

2.10. Post-fire Average Water Storage at the Barrier, (a) North Plots, (b) South Plots, (c) Northwest and Southwest Plots, and (d) Northeast and Southeast Plots.

2.11. Rate of Drainage from the Side-slope Plots at the Prototype Hanford Barrier for the Period September 1994 Through August 2009.

2.12. Rate of Drainage from the Silt-loam Plots at the Prototype Hanford Barrier for the Period September 1994 Through August 2009.

2.13. Cumulative Amounts of Water Diverted by the Asphalt Pad (Drainage) from the SideSlope Plots at the Prototype Hanford Barrier in September 1994 Through August 2009.

2.14. Cumulative Amounts of Water Diverted by the Asphalt Pad (Drainage) from the Silt Loam Plots at the Prototype Hanford Barrier in September 1994 Through August 2009.

2.15. Cumulative Amounts of Water by Water Year Diverted by the Asphalt Pad (Drainage) From the Side-Slope Plots at the Prototype Hanford Barrier in September 1994 Through August 2009 as a Percentage of Precipitation.

2.16. Spatiotemporal Variations in Soil-Water Content at the Bottom of the Silt-Loam Layer of the Irrigated Treatment of the Barrier: (a) northern end of treatment, tube AA1 + AA5, and (b) southern end of treatment, tube AA2 + AA6. 
2.17. Spatiotemporal Variations in Soil-Water Content at the Bottom of the Silt-Loam Layer of the Nonirrigated Treatment of the Barrier: (a) northern end of treatment, tube AA3 + AA7, and (b) southern end of treatment, tube AA4 +AA8

2.18. Spatial Variation in Soil-Water Content Under the Asphalt Layer (Uncurbed Section) on March 28, 1995, and, May 23, 2008: horizontal neutron tubes (a) BA 1 at 1m, (b) BA 3 at $2 \mathrm{~m}$, (c) BA 5 at $3 \mathrm{~m}$, (d) BA 2 at $1 \mathrm{~m}$, (e) BA 4 at $2 \mathrm{~m}$, and (f) BA 6 at $3 \mathrm{~m}$.

2.19. Spatial Variation in Soil-Water Content Under the Asphalt Layer (Uncurbed Section) on March 28, 1995, and, June 30, 2009: horizontal neutron tubes (a) BA 1 at 1m, (b) BA 3 at $2 \mathrm{~m}$, (c) BA 5 at $3 \mathrm{~m}$, (d) BA 2 at $1 \mathrm{~m}$, (e) BA 4 at $2 \mathrm{~m}$, and (f) BA 6 at $3 \mathrm{~m}$. .34

2.20. Evapotranspiration on the Silt-covered Plots Calculated Using the Water Balance Equation. 36

2.21. Comparison of Average Evapotranspiration Rate at the Prototype Hanford Barrier: (a) North Plots, 6W and 6E, and (b) South Plots, 3W and 3E.

3.1. Net Creep Gauge Movement Between September 2008 and July 2009. (Elevation measured by EDM until FY 2003, subsequent measurements by GPS; the resultant [horizontal component] is in meters).

3.2. Net Creep Gauge Movement Between May December 1994 and July 2009. (Elevation measured by EDM until FY 2003, subsequent measurements by GPS; the resultant [horizontal component] is in meters).

3.3. Surface Elevation (meters) as the Prototype Hanford Barrier at Three Different Times, (a) December 1994 (b) September 4, 2008, and (c) July 29, 2009. FY 1994 measurements were made using an Electronic Distance Measurement unit whereas FY 2008 and FY 2009 measurements were made using a Trimble real-time kinematic GPS. The contour interval is $0.025 \mathrm{~m}$.

3.4. Surface Elevation (10× Vertical Exaggeration) at the Prototype Hanford Barrier as of July 29, 2009 Measured Using a Real-Time Kinematic Global Position System.

3.5. Change in Surface Elevation ( $66 \times$ Vertical Exaggeration) at the Prototype Hanford Barrier as of July 29, 2009 Measured Using a Real-Time Kinematic Global Position System.

4.1. Prototype Hanford Barrier Cover Dominated by Artemisia tridentata in 2007, 15 Years After Establishment.

4.2. South (originally unirrigated) Section of Prototype Hanford Barrier Cover Dominated by Artemisia tridentata in 2009, 15 Years After Establishment.

4.3. Temporal variation in the number of annual/biennials and perennial species including total species on the Prototype Hanford Barrier.

4.4. Cryptogamic Crust Covering Most of the Soil Surface. Bright Patches on the Surface are Bare Soil.

4.5. Soil cryptogams. The Orange Lichen is Caloplaca tominii and the Moss is Bryum cf. caespiticium (Link et al. 2000).

4.6. Mean Cover on North Half of the Barrier Before the Fire. Error bars of one standard error of the mean $(n=144)$. Different letters indicate significant differences. 
4.7. Mean Cover on South Half of the Barrier. Error bars of one standard error of the mean $(n=144)$. Different letters indicate significant differences.

4.8. Mean cover on the north and west side slopes of the barrier. Error bars of one standard error of the mean. Different letters indicate significant differences.

\section{Tables}

2.1. Expected Measurement Precision for Prototype Hanford Barrier Monitoring 6

2.2. Annual and Seasonal Natural Precipitation for the Hanford Site, 1994 Through 2009 8

2.3. Amounts of Water Diverted by the Asphalt Pad (Drainage) from the North Plots at the Prototype Hanford Barrier and the Relationship to Barrier Precipitation

2.4. Amounts of Water Diverted by the Asphalt Pad (Drainage) from the South Plots at the Prototype Hanford Barrier and the Relationship to Barrier Precipitation

3.1. Elevations and Elevation Changes of Settlement Gauges from December 1994 for Through July 2009

4.1. Plant species observed in 2009 on the Burned and Unburned Sections of the Barrier.

4.2. Plant species found in the Columbia Basin. Species type are "N" = native, "A" = alien, "AF" = annual forb, "AG" = annual grass, "BF" = biennial forb, "PF" = perennial forb, "PG" = perennial grass, "S" = shrub, "R" = seeded or planted species .55

4.3. Plant Species Observed in 2009 on the West and North Side-slopes of the Barrier

4.4. Lichens and mosses occurring on soils of the unburned half of the barrier.

4.5. Median, Mode, and Mean Percent Cover Classes Ranges for Grass

4.6. Median, Mode, and Mean Percent Cover Classes Ranges for Shrubs 63

4.7. Median, Mode, and Mean Percent Cover Classes Ranges for Litter .64

4.8. Median, Mode, and Mean Percent Cover Classes Ranges for Bare Ground .65

4.9. Mean percent cover ( $\pm 1 \mathrm{sem})$ of plant species and other categories observed in 2009 .66

4.10. Mean shrub density \pm 1 standard error of the mean (plants $\mathrm{m}^{-2}$ ). 69

4.11. Mean size/age density (plants $\mathrm{m}^{-2}$ ) \pm 1 standard error of the mean of A. tridentata 69 



\section{Terms}

$\begin{array}{ll}\text { AP } & \text { Aerial Photogrammetry } \\ \text { CERCLA } & \text { Comprehensive Environmental Response, Compensation, and Liability Act of 1980 } \\ \text { DEM } & \text { digital elevation model } \\ \text { DOE-RL } & \text { U.S. Department of Energy Richland Operations } \\ \text { DP } & \text { deep percolation } \\ \text { ECHO } & \text { ECH } 2 \text { O, moisture sensor system (Decagon Devices, Inc.) } \\ \text { EDM } & \text { electronic distance measurement } \\ \text { EMI } & \text { electromagnetic induction } \\ \text { ET } & \text { evapotranspiration } \\ \text { FY } & \text { fiscal year } \\ \text { GPR } & \text { ground-penetrating radar } \\ \text { GPS } & \text { global positioning system } \\ \text { HMS } & \text { Hanford Meteorological Station } \\ \text { PNNL } & \text { Pacific Northwest National Laboratory } \\ \text { PSB } & \text { Prototype surface barrier } \\ \text { RTK } & \text { real time kinematic } \\ \text { TDR } & \text { time domain reflectometry } \\ \text { WY } & \text { water year }\end{array}$




\subsection{Introduction}

Engineered surface barriers constructed of natural materials are recognized as a remedial alternative to the removal, treatment and disposal of near-surface contaminants at a variety of waste sites within the DOE complex. Implicit in the long-term performance objectives is that multilayered or composite covers like the Hanford barrier have a service life of a hundreds or even thousands of years and limit recharge to 0.5 mm per year or less. Evapotranspiration covers can also be an effective alternative to composite covers in arid and semiarid climates (NRC, 2007). However, the basis for selecting a particular barrier design and its constituents is still based one of two approaches, (i) the use of numerical models, and (ii) expert judgment based laboratory, lysimeter, and field tests. The uncertainty in both methods increases considerably when it becomes necessary to predict performance and service lives beyond the accumulated knowledge of controlled tests. However, engineered barriers have not been in existence long enough to assess long-term or post-closure performance for the periods of interest. In fact, much of the available data are derived from monitoring the environment downgradient of the barriers, and there is a paucity of data from the direct monitoring of the barriers themselves. Thus, significantly more data over much longer time frames and/or studies of natural analogs that have functioned for hundreds or thousands of years are required to make a reliable prediction of the long-term performance of engineered barriers. This requirement is true regardless of the barrier is of a capacitive (mono or multilayer), evapotranspiration (ET), or hybrid (ET + capacitive) cover.

Monitoring is an essential component of engineered barrier system design and operation. A composite capacitive cover, including a capillary break and an ET barrier at the Hanford Site is generating data that can be used to help resolve these issues. The prototype Hanford barrier was constructed over the 216-B57 Crib in 1994 to evaluate surface-barrier constructability, construction costs, and physical and hydrologic performance at the field scale. The barrier has been routinely monitored between November 1994 and September 1998 as part of a Comprehensive Environmental Response, Compensation, and Liability Act of 1980 (CERCLA) (42 USC 9601) treatability test of barrier performance for the 200-BP-1 Operable Unit. The results of the 4-year (fiscal years [FY] 1995 to 1998) treatability test are documented in 200-BP-1 Prototype Barrier Treatability Test Report (DOE-RL 1999). Since FY 1998, monitoring has focused on a more limited set of key water balance, stability, and biotic parameters with results summarized in annual letter reports (CCN 073428, "200-BP-1 Prototype Hanford Barrier Annual Monitoring Report for FY 1999”; CCN 083132, “200-BP-1 Prototype Hanford Barrier Annual Monitoring Report for Fiscal Year 2000”; CCN 100381, “200-BP-1 Prototype Hanford Barrier Annual Monitoring Report for FY 2001”; CP 14873, “200-BP-1 Prototype Hanford Barrier Annual Monitoring Report for FY 2002"; and CP 18187, "200-BP-1 Prototype Hanford Barrier Annual Monitoring Report for FY 2003"), and a published report for FY 2004 (Ward et al, 2005). There was no summary report for FY 2005 but a comprehensive report covering FY 2005 through FY 2007 was published in December 2007 (Ward et al, 2007). As in previous years, data collection has focused on:

- Water-balance monitoring, consisting of precipitation, runoff, soil moisture storage, and drainage measurements with evapotranspiration calculated by difference

- Stability monitoring, consisting of asphalt-layer-settlement, basalt-side-slope-stability, and surfaceelevation measurements

- Vegetation dynamics

- Animal use 
September 2009 marked 15 years since the start of monitoring and the collection of performance data. This report describes the results of monitoring activities during the period October 1, 2008 through September 30, 2009 and summarizes the 15 years of performance data collected from September 1994 through September 2009. All data collected through September 2009 are included on a compact disc. 


\subsection{Water Balance Monitoring}

Water balance is the most comprehensive approach to the assessment of the field-scale hydrologic performance of an engineered barrier. At the prototype Hanford barrier, hydrologic monitoring has focused on select components of the water-balance. A simplified water balance for the prototype barrier can be written as follows:

$$
P-D-D P-R-\Delta W-E T=0
$$

where

$$
\begin{aligned}
P & =\text { natural precipitation } \\
D & =\text { drainage out of the soil cover (diverted by the asphalt) } \\
D P & =\text { deep percolation (vertical drainage past the asphalt layer) } \\
R & =\text { surface runoff } \\
\Delta W & =\text { change in soil-water storage } \\
E T & =\text { Evapotranspiration. }
\end{aligned}
$$

Evapotranspiration (ET) is the only component not measured; it is calculated by solving Equation 2.1:

$$
E T=P-(D+D P+R+\Delta W) .
$$

The change in storage, $\Delta \mathrm{W}$, is calculated as the difference in $\mathrm{W}$ measured at different times. Soil-water storage, $\mathrm{W}$, is calculated from measurements of soil-water content, $\theta$, by integrating $\theta$ over depth profiles. Thus, $\mathrm{W}$ between the surface and depth, $z$, is calculated as follows:

$$
W=\int_{0}^{L} \theta(z) d z \approx L_{1} \theta_{1}+\sum_{i=1}^{n-1} L_{i+1} \frac{\left(\theta_{i}-\theta_{i+1}\right)}{2}
$$

where

$L=$ total depth of characterization $(2 \mathrm{~m})$

$\theta_{l}=$ volumetric soil-water content at the first measurement points

$L_{l}=$ distance from surface to first measurement point

$n=$ number of measurement points

$\theta_{i}=$ volumetric soil-water content at the $\mathrm{i}^{\text {th }}$ depth in the profile

$L_{i}=$ distance between successive measurement points.

Water balance components monitored over the reporting period include precipitation, runoff, water storage, drainage (water diverted by the asphalt layer), and deep percolation (leakage through the asphalt layer). In addition to monitoring the water-balance components, horizontal distributions of soil-water content were measured at the capillary break (silt loam-sand filter interface) and beneath the asphalt layer. A pan lysimeter beneath the northeast corner of the asphalt layer also was monitored routinely for leakage, which, in this case, is analogous to deep drainage and would represent potential recharge through the cover. 


\subsection{Methodology}

To monitor the water-balance components in the top 2-m silt-loam layer of the barrier, the surface is fitted with 14 water-balance monitoring stations (S1 through S14; Figure 2.1). The stations are arranged with three in each of the four silt-loam-covered plots $(3 \mathrm{~W}, 3 \mathrm{E}, 6 \mathrm{~W}$, and $6 \mathrm{E})$ and one in each of the two gravelcovered plots ( $1 \mathrm{~W}$ and $4 \mathrm{~W})$.

The temporal and spatial distribution of precipitation is particularly important to understanding barrier performance and is monitored using precipitation meters installed at each monitoring station. The meters are described in DOE-RL (1999). Data currently are being collected on an hourly basis and are supplemented with precipitation data from the Hanford Meteorological Station. This report includes only temporal averages of precipitation. More detailed spatial and temporal information is stored in the project database and can be made available in an electronic format.

Surface runoff is monitored through the use of a 6.1 -m-wide by 15.2-m-long erosion flume located in the northwest section of the barrier (Figure 2.1). The erosion flume is designed to capture and convey runoff to an automated water and sediment sampler. Water storage is monitored using vertical water content measurements taken by a neutron hydroprobe (Procedure for Measuring Soil Moisture Using the Neutron Probe in the Neutron Probe Access Tube Vertical and Horizontal Array [PNNL 1995]) and by time domain reflectometry (TDR) (Measuring Soil Water Content With the Moisture Point Time Domain Reflectometry System [PNNL 1999]).

For monitoring the drainage component, D, in Equation 2.2, the barrier is equipped with an automated drainage-monitoring system. A monitoring system is housed in each of 12 concrete vaults located to the north and down-gradient from the asphalt layer to allow the movement of water by gravity (DOE-RL 1999). A series of curbs divides the surface of the asphalt into 12 water-collection zones, the boundaries of which align vertically with the 12 surface plots shown in Figure 2.2. Water reaching the curbed asphalt from the upper layers is piped to the drainage vaults. Under low flows into the vault, water flows through a datalogger-controlled tipping-bucket rain gauge which monitors the flow rate. At higher flows, the system is designed for water to bypass the tipping buckets. Flow rate is then determined from the rate of change in hydrostatic pressure in the vault. Hydrostatic pressure is a function of water level in the vault and is automatically measured and recorded using pressure transducers. The combination of hourly tipping bucket and pressure transducer measurements provides good temporal resolution of range of flow rates into the vaults. Detailed instructions on the measuring procedure are contained in Procedures for Routine Maintenance and Calibration of Dosing Siphons at the Prototype Surface Barrier (PNL 1995).

Monitoring of deep percolation (DP) is facilitated by a $6.5-\mathrm{m}$ by $6.5-\mathrm{m}$ pan lysimeter installed under the northeast section (centered on plot 4E) of the asphalt layer (DOE-RL 1999). The lysimeter, which resembles an inverted pyramid, is sealed around the perimeter to the underside of the asphalt layer. A pair of 1.65-mm-diameter stainless steel tubes is used for venting and siphoning water from the bottom of the lysimeter. Any water siphoned from the lysimeter tube is routed to a tipping bucket and monitored by a datalogger. The lysimeter is monitored once every 24 hours.

Although not specifically used to assess water storage, neutron logging in horizontal access tubes is used to monitor several zones of the barrier for changes in the soil moisture content. At the west side of the prototype surface barrier, two pairs of U-shaped horizontal access tubes were installed at $1.95 \mathrm{~m}$ below the surface, near the capillary break (silt loam-sand filter interface) (AA1, AA2, AA3, AA4; Figure 2.2). A similar set of tubes (AA5, AA6, AA7, AA8) was installed at $1.95 \mathrm{~m}$ on the east side. Three additional sets of tubes were installed under the northeast section of the barrier below the asphalt layer. Tubes BA1 
and BA2 were installed at a depth of $1 \mathrm{~m}$ below the asphalt, tubes BA3 and BA4 at $2 \mathrm{~m}$, and tubes BA5 and BA6 at 3 m below the asphalt layer. The northeast corner of the asphalt layer (under the north buffer zone) was left uncurbed to assess the amount of underflow at the edge of the asphalt.

Table 2.1 summarizes the measurements taken at the barrier, and the measurement precision of each instrument. Surface elevations were measured using two additional techniques, 1) aerial photogrammetry and 2) a real time kinematic (RTK) global positioning system (GPS). The measurement precision of these techniques is also summarized in Table 2.1. 


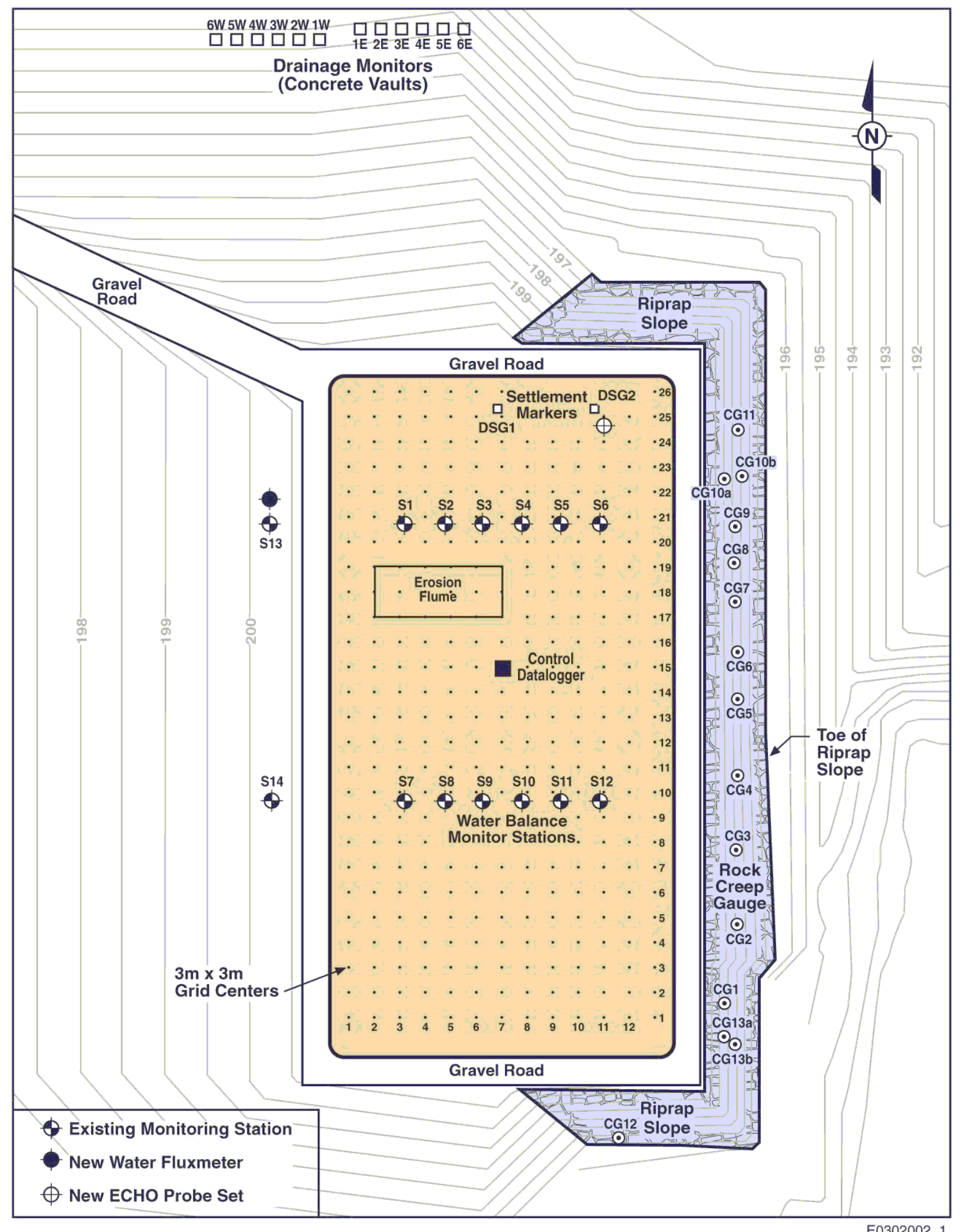

Figure 2.1. Plan View of the Prototype Hanford Barrier Showing Monitoring Stations 


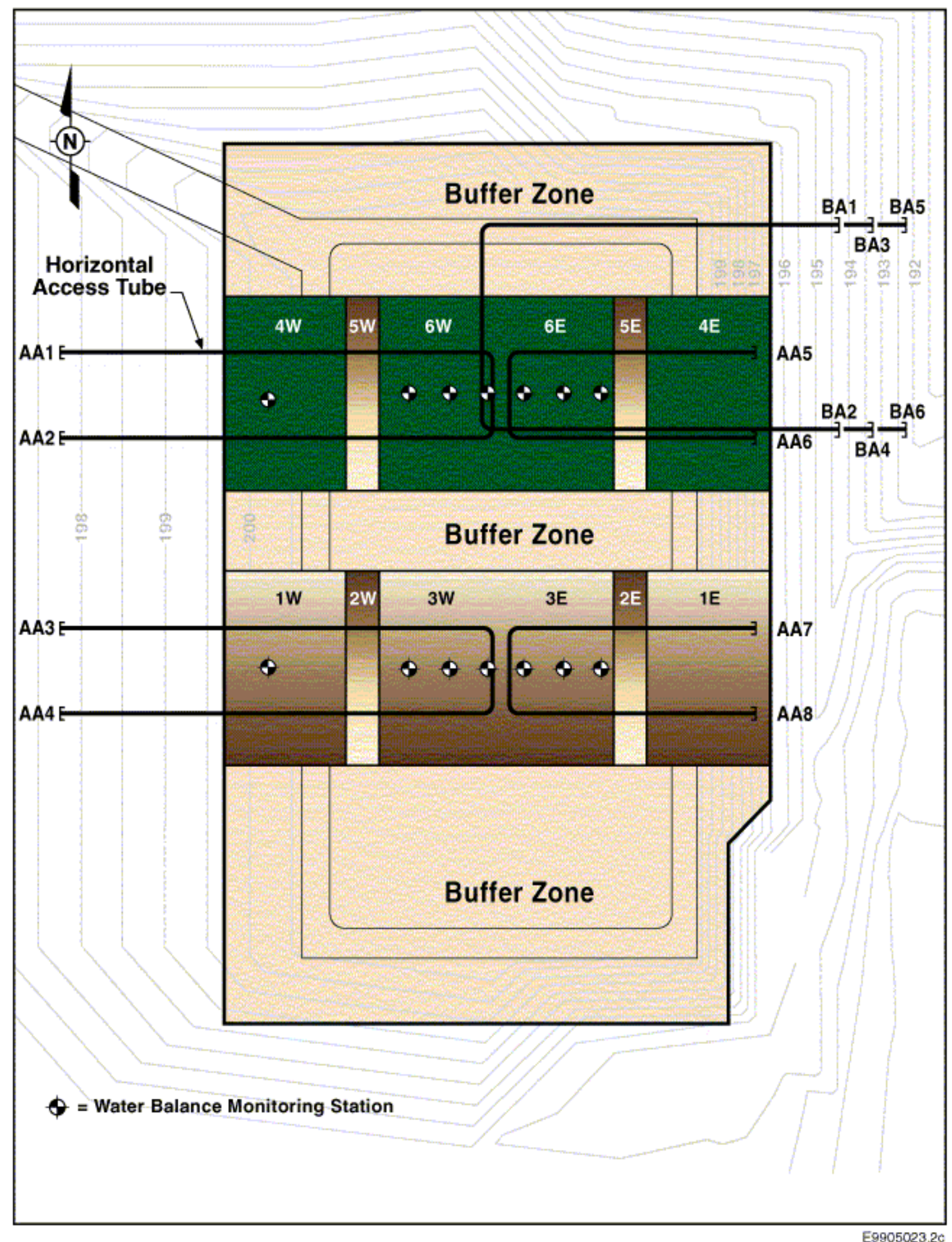

Figure 2.2. Plan View of the Prototype Hanford Barrier Showing the Layout of the 12 Surface Soil Plots (1W to 6W and 1E to 6E) and Horizontal Neutron Access Tubes (AA Above Asphalt; BA Below Asphalt) 
Table 2.1. Expected Measurement Precision for Prototype Hanford Barrier Monitoring

\begin{tabular}{|c|c|c|c|}
\hline Variable & Measurement Method & Resolution & Expected Precision \\
\hline Precipitation, $\mathrm{P}(\mathrm{mm})$ & Load cells & $\pm 0.2 \mathrm{~mm}$ & $\pm 0.2 \mathrm{~mm}$ \\
\hline Water storage, W (mm) & $\begin{array}{l}W=\int_{0}^{L} \theta(z) d z, \\
\theta \text { measured from surface to } \\
\text { depth } L \text { by neutron probe } \\
\text { and time domain } \\
\text { reflectometry (TDR) }\end{array}$ & $\begin{array}{l}\text { Neutron probe: } \\
\pm 0.005 \mathrm{~m}^{3} \mathrm{~m}^{-3} \\
\text { TDR: } \pm 0.003 \mathrm{~m}^{3} \mathrm{~m}^{-3} \\
\text { ECHO }: \pm 0.001 \mathrm{~m}^{3} \mathrm{~m}^{-3}\end{array}$ & $\begin{array}{l}\text { Neutron probe: } \pm 10.0 \mathrm{~mm} \\
\text { over depth } \mathrm{L} \text {, subject to } \\
\text { confidence interval of } \\
\text { calibration curve } \\
\text { TDR: } \pm 6.0 \mathrm{~mm} \text { over depth } \mathrm{L} \\
\text { ECHO: } \pm 2.0 \mathrm{~mm} \text { over L }\end{array}$ \\
\hline Surface runoff, R (mm) & Isco flowmeter $^{b}$ & $\pm 0.25 \mathrm{~mm}$ & $\pm 0.25 \mathrm{~mm}$ \\
\hline & Tipping-bucket gauge & $\pm 0.025 \mathrm{~mm}$ & $\begin{array}{l}\text { Main plot: } 3.52 \times 10^{-5} \mathrm{~mm} \\
\text { Trans plot: } 7.04 \times 10^{-5} \mathrm{~mm}\end{array}$ \\
\hline Drainage, $\mathrm{D}(\mathrm{mm})$ & Pressure transducer & $\pm 0.025 \mathrm{~mm}$ & $\begin{array}{l} \pm 0.26 \mathrm{~mm} \mathrm{yr}^{-1} \text {; controlled by } \\
\text { seepage through walls of } \\
\text { vault }\end{array}$ \\
\hline $\begin{array}{l}\text { Evapotranspiration, ET } \\
(\mathrm{mm})\end{array}$ & $\begin{array}{l}\text { By difference; } \\
\mathrm{ET}=\mathrm{P}-(\mathrm{D}+\mathrm{DP}+\mathrm{R}+\Delta \mathrm{W})\end{array}$ & $\begin{array}{l}\text { Set by least precise } \\
\text { component, } \Delta \mathrm{W}\end{array}$ & $\pm 10 \mathrm{~mm}$ \\
\hline \multirow{3}{*}{ Elevation, distance (m) } & $\begin{array}{l}\text { Electronic distance } \\
\text { measurement system }\end{array}$ & $5 \mathrm{~mm}+5 \mathrm{ppm}$ & $5 \mathrm{~mm}+5\left(\right.$ distance $\left./ 10^{6}\right)$ \\
\hline & Digital Photogrammetry & $\begin{array}{l}\text { Horizontal: } 3 \mathrm{~mm}+ \\
0.5 \mathrm{ppm}(\times \text { baseline } \\
\text { length) } \\
\text { Vertical: } 5 \mathrm{~mm}+ \\
0.5 \mathrm{ppm}(\times \text { baseline } \\
\text { length) }\end{array}$ & $\begin{array}{l}\text { Horizontal: } 3 \mathrm{~mm}+0.5 \\
\left.\text { (distance } / 10^{6}\right) \\
\text { Vertical: } 5 \mathrm{~mm}+0.5 \\
\text { (distance } / 10^{6} \text { ) }\end{array}$ \\
\hline & Global Positioning System & $\begin{array}{l}\text { Horizontal: } 5 \mathrm{~mm}+ \\
0.5 \mathrm{ppm}(\times \text { baseline } \\
\text { length) } \\
\text { Vertical: } 5 \mathrm{~mm}+ \\
2.0 \mathrm{ppm}(\times \text { baseline } \\
\text { length) }\end{array}$ & $\begin{array}{l}\text { Horizontal: } \\
5 \mathrm{~mm}+0.5\left(\text { distance } / 10^{6}\right) \\
\text { Vertical: } \\
5 \mathrm{~mm}+2.0\left(\text { distance } / 10^{6}\right)\end{array}$ \\
\hline
\end{tabular}




\subsection{Results}

\subsubsection{Precipitation}

Table 2.2 summarizes the precipitation at the Hanford Site on a seasonal basis and by water year (WY) for the duration of monitoring at the prototype barrier. These data are derived from measurements taken at the Hanford Meteorological Station (HMS) and are discussed in greater detail in climatological data summaries for the Hanford Site (e.g., Hoitink et al. 2005). For the period October 1, 2007 through September 30, 2008, precipitation amounted to $138.43 \mathrm{~mm}$ compared to the normal amount of 176.72 $\mathrm{mm}$. During the reporting period October 1, 2008 through September 30, 2009, precipitation amounted to $135.38 \mathrm{~mm}$. Over the last 15 years, water year totals have ranged from a low of $119.89 \mathrm{~mm}(68 \%$ of normal) in WY 2005 to $289.31 \mathrm{~mm}$ (64\% above normal) in WY 1997.

Over the last 15 years, seasonal distribution of precipitation has shown significant variability. The highest winter precipitation for the monitoring period was $138.4 \mathrm{~mm}$, observed in FY 1997. This amount is over four times the low of $34 \mathrm{~mm}$ recorded in the winter of FY 2005 and some $211 \%$ of normal. In FY 2008, winter precipitation amounted to $59.94 \mathrm{~mm}$, compared to the normal $65.56 \mathrm{~mm}$. Of the total FY 2009 precipitation, $69.60 \mathrm{~mm}$ occurred during the winter (December 2008 through February 2009). Total precipitation has shown a general decrease from 1994 through 2009. A similar trend is obvious in the winter, except for 2003 and 2004, and spring although summer precipitation has been more erratic (Table 2.2). Spring and autumn precipitations totals are less than normal in both FY 2008 and 2009.

Seasonal variations in precipitation are particularly important when evaluating cover performance and must be taken into consideration when selecting candidate barrier designs. Composite capacitive barriers and hybrid evapotranspiration and capacitive barriers are commonly designed store the expected winter precipitation until it can be recycled to the atmosphere during the spring and summer months. Thus, performance will be impacted by the temporal distribution of precipitation. Over the last 15 years, shortterm variations in total and seasonal precipitation are evident which, as will be shown later, are reflected in changes in water storage and side-slope drainage. This suggests a need for consideration of the shortterm variation in precipitation as a design variable rather than the normal or long-term average precipitation values. The prototype Hanford barrier is designed with a 2-m silt-loam layer capable of storing approximately $600 \mathrm{~mm}$ of water, which is more than three times the long-term average precipitation $\left(160 \mathrm{~mm} \mathrm{yr}^{-1}\right)$ for the site. This capacity has never been exceeded, not even during the treatability test, which included three simulated 1000-yr return storm events. Figure 2.3 presents a summary of the cumulative ambient and total precipitation at the 200-BP-1 barrier for the period October 1994 through September 30, 2009. During this period, the barrier received a total of $3312.9 \mathrm{~mm}$ of water of which $2640 \mathrm{~mm}$ came from natural precipitation and $672.87 \mathrm{~mm}$ came from irrigation during the treatability test. 
Table 2.2. Annual and Seasonal Natural Precipitation for the Hanford Site, 1994 Through 2009

\begin{tabular}{|c|c|c|c|c|c|}
\hline \multirow[b]{2}{*}{ Water Year ${ }^{(a)}(W Y)$} & \multirow[b]{2}{*}{ WY Total ${ }^{(b)}$} & \multicolumn{4}{|c|}{ Precipitation (mm) } \\
\hline & & $\begin{array}{c}\text { Winter } \\
(\text { Dec-Feb })^{(c)}\end{array}$ & $\begin{array}{c}\text { Spring } \\
\text { (Mar-May) }\end{array}$ & $\begin{array}{c}\text { Summer } \\
\text { (Jun-Aug) }\end{array}$ & $\begin{array}{c}\text { Autumn } \\
\text { (Sep-Nov) }\end{array}$ \\
\hline 1995 & 280.67 & 106.43 & 83.31 & 29.97 & 68.58 \\
\hline 1996 & 233.17 & 125.98 & 47.75 & 5.33 & 95.76 \\
\hline 1997 & 289.31 & 138.43 & 34.54 & 18.03 & 57.15 \\
\hline 1998 & 169.67 & 68.58 & 27.69 & 21.84 & 42.42 \\
\hline 1999 & 125.73 & 51.56 & 10.16 & 24.13 & 18.80 \\
\hline 2000 & 166.88 & 57.91 & 57.91 & 18.03 & 56.13 \\
\hline 2001 & 155.96 & 35.05 & 42.67 & 35.56 & 55.12 \\
\hline 2002 & 136.91 & 48.01 & 16.26 & 20.83 & 12.70 \\
\hline 2003 & 224.03 & 128.27 & 65.28 & 11.68 & 11.68 \\
\hline 2004 & 218.95 & 126.49 & 37.08 & 45.72 & 32.77 \\
\hline 2005 & 119.89 & 34.04 & 34.54 & 5.33 & 46.74 \\
\hline 2006 & 214.12 & 91.44 & 53.59 & 33.78 & 42.67 \\
\hline 2007 & 173.48 & 67.31 & 33.02 & 21.34 & 48.51 \\
\hline 2008 & 138.43 & 59.94 & 21.34 & 22.10 & 25.40 \\
\hline 2009 & 135.38 & 69.60 & 34.80 & 4.06 & NA \\
\hline Normal $^{(\mathrm{d})}$ & 176.72 & 65.56 & 40.13 & 24.13 & 45.72 \\
\hline Barrier average $^{(\mathrm{e})}$ & 185.51 & 67.56 & 40.13 & 24.13 & NA \\
\hline Standard deviation & 54.84 & 36.00 & 19.23 & 11.83 & $\mathrm{NA}$ \\
\hline \multicolumn{6}{|c|}{$\begin{array}{l}\text { (a) The water year (WY) corresponds to the Federal fiscal year and runs from October } 1 \text { of the previous calendar year } \\
\text { through September } 30 \text { of the following calendar year. For example WY2008 extends from October 1, } 2008 \\
\text { through September } 30,2009 \\
\text { (b) WY total is total precipitation for the stated water year. } \\
\text { (c) Winter precipitation for a given WY includes precipitation for December of the previous calendar } \\
\text { year plus precipitation for January and February of the current year. } \\
\text { (d) Normal is the } 30 \text {-year average based on the period from } 1971 \text { through } 2000 \text {. } \\
\text { (e) Barrier average is the average over the period of monitoring, October 1, } 1994 \text { through September } 30,2009 .\end{array}$} \\
\hline
\end{tabular}




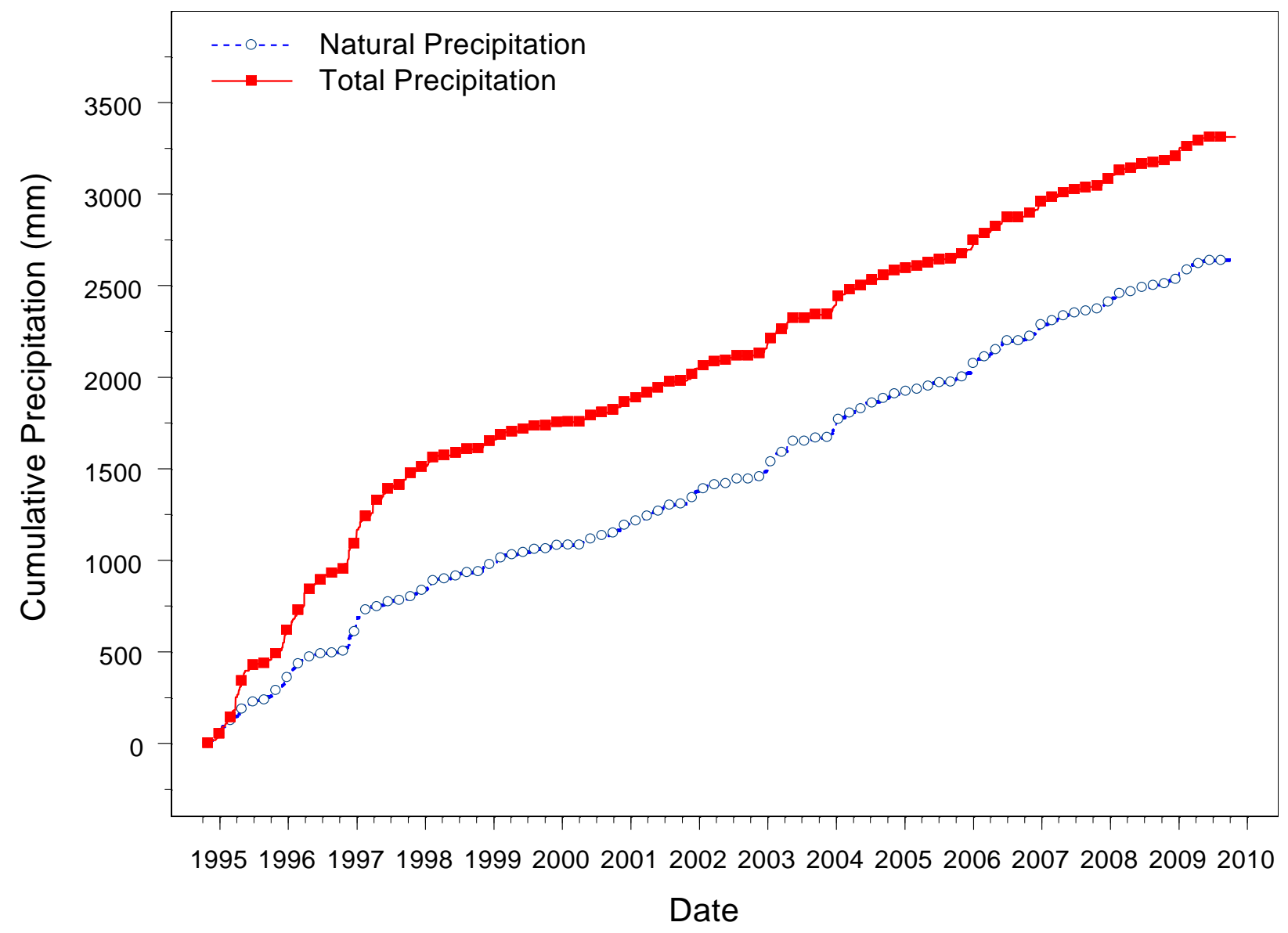

Figure 2.3. Natural and Total Precipitation (Natural plus Irrigation) at the Prototype Hanford Barrier From October 1, 1994, September 30, 2009. 


\subsubsection{Soil-Water Storage}

Water storage, $\mathrm{W}$, is calculated from water contents measured with a neutron probe and TDR. The TDR system became nonfunctional during the latter part of FY 2008 and data collection was interrupted.

Nonetheless, use of the neutron-probe for measuring vertical water content profiles continued on a regular basis. Measured soil-water contents were used to calculate soil-water storage as a function of time, W(t), using Equation 2.3. Figure 2.4 through Figure 2.7 show distributions of $\mathrm{W}(\mathrm{t})$ on the silt-loam plots from September 30, 1994, through September 19, 2009, derived from the neutron-probe measurements Figure 2.4 summarizes water storage measured on the northwestern quadrant (Figure 2.1) of the barrier's surface. Figure 2.5 summarizes water storage measured on the northeastern quadrant of the barrier's surface. Figure 2.6 and Figure 2.7 show the water storage measured on the southwestern and southeastern quadrants, respectively. All plots show a well-defined annual cycle in $\mathrm{W}(\mathrm{t})$ for the duration of monitoring. The break in the water storage record observed from September 30, 1998 through May 05, 2000 (FY 1999) was due to a hiatus in monitoring. Another break in the record occurred from December 08, 2004 through September 09, 2005 (FY 2005) and no water storage data were recorded.

Figure 2.4 shows the temporal pattern in water storage on plot $6 \mathrm{~W}$ in the northwestern quadrant of the barrier whereas Figure 2.5 shows data for plot $6 \mathrm{E}$ located in the northeastern quadrant, both on the north half of the barrier. The most striking observation is the elevated water storage observed on the two quadrants during the treatability test. This is expected as the north half of the barrier was irrigated at a rate $480 \mathrm{~mm} / \mathrm{yr}$, which is equal to three times the long-term annual precipitation for Hanford. The north half of the barrier was irrigated from FY 1995 through FY 1998 as part of a 3-yr CERCLA treatability test and showed the largest values of storage during this period and for almost two years after the cessation of irrigation (Figure 2.4, Figure 2.5). Although water storage approached the design storage capacity in 1997, the wettest year on record, the design capacity was never exceeded and no drainage occurred from the fine-soil layers.

Another striking feature is a dependence of water storage on spatial location. In general water storage near the west (S501) and east (S506) edges of the barrier is higher than at the mid-slope (S502, S505), and upper slope (S503, S506) positions. This observation is related to the topography of the upper soil layers. The barrier was constructed with a $2 \%$ slope from the middle towards the east and west edges so as to direct overland and interflow away from the crown. The spatial differences in storage provide some insight into the factors controlling storage and suggest a need to consider alternate designs of the interface between the fine-soil layer and the protective side slopes. The cross section of the current design is an inverted isosceles trapezoid with a $45^{\circ}$ interface between the fine soil and side slope. As such, the water storage capacity of the soil layer near the edge is about 50\% smaller than at the mid and upper slope positions. A regular isosceles trapezoid (short side on top, log side on bottom) would eliminate this problem and increase the storage capacity. The dependence of storage on slope position may also have some implications for water balance calculations on field-scale covers. One-dimensional or twodimensional isotropic simulations of infiltration and storage changes are unable to account for interflow and would predict a spatially independent distribution of storage. The immediate effect would be an overestimation of evapotranspiration, which is typically calculated as the difference between precipitation inputs, water storage and water losses (runoff, percolation). One-dimensional or isotropic twodimensional simulations would be unable to account for interflow. The result would be an error in storage calculations that would likely exceed the drainage criterion of the cover. The accumulation of water at the edges could also be a mechanism for local side-slope integrity failure for shallow slopes. Designs of the interface between the fine soil layer and the protective side-slope that increases the storage capacity of this zone may therefore be necessary to minimize the potential for local side-slope failure. 


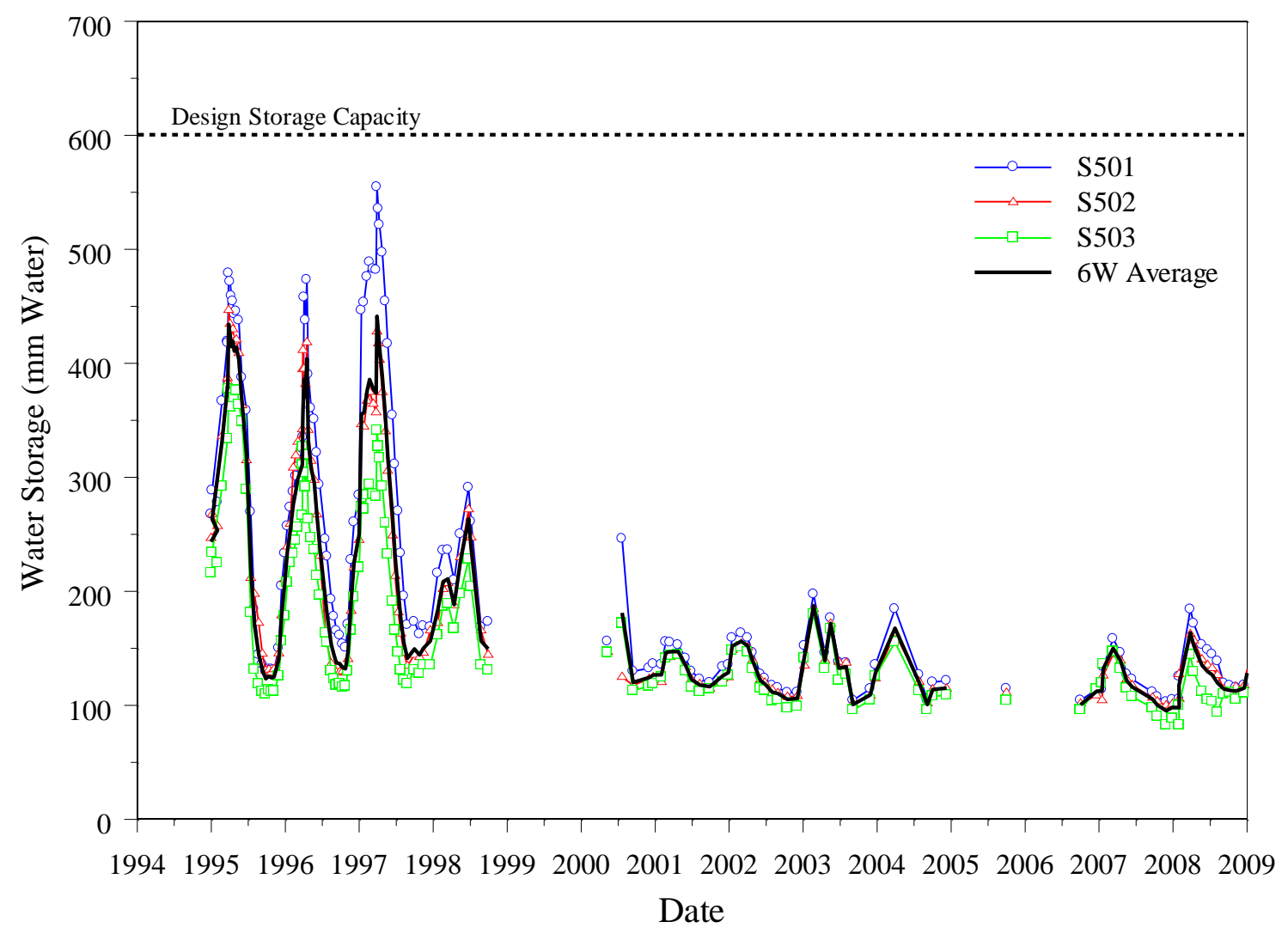

Figure 2.4. Temporal Variation in Soil-Water Storage in Northwest Plot 6W at the Prototype Hanford Barrier, October 1994 Through September 2009 (design water storage capacity is $600 \mathrm{~mm}$ ) 


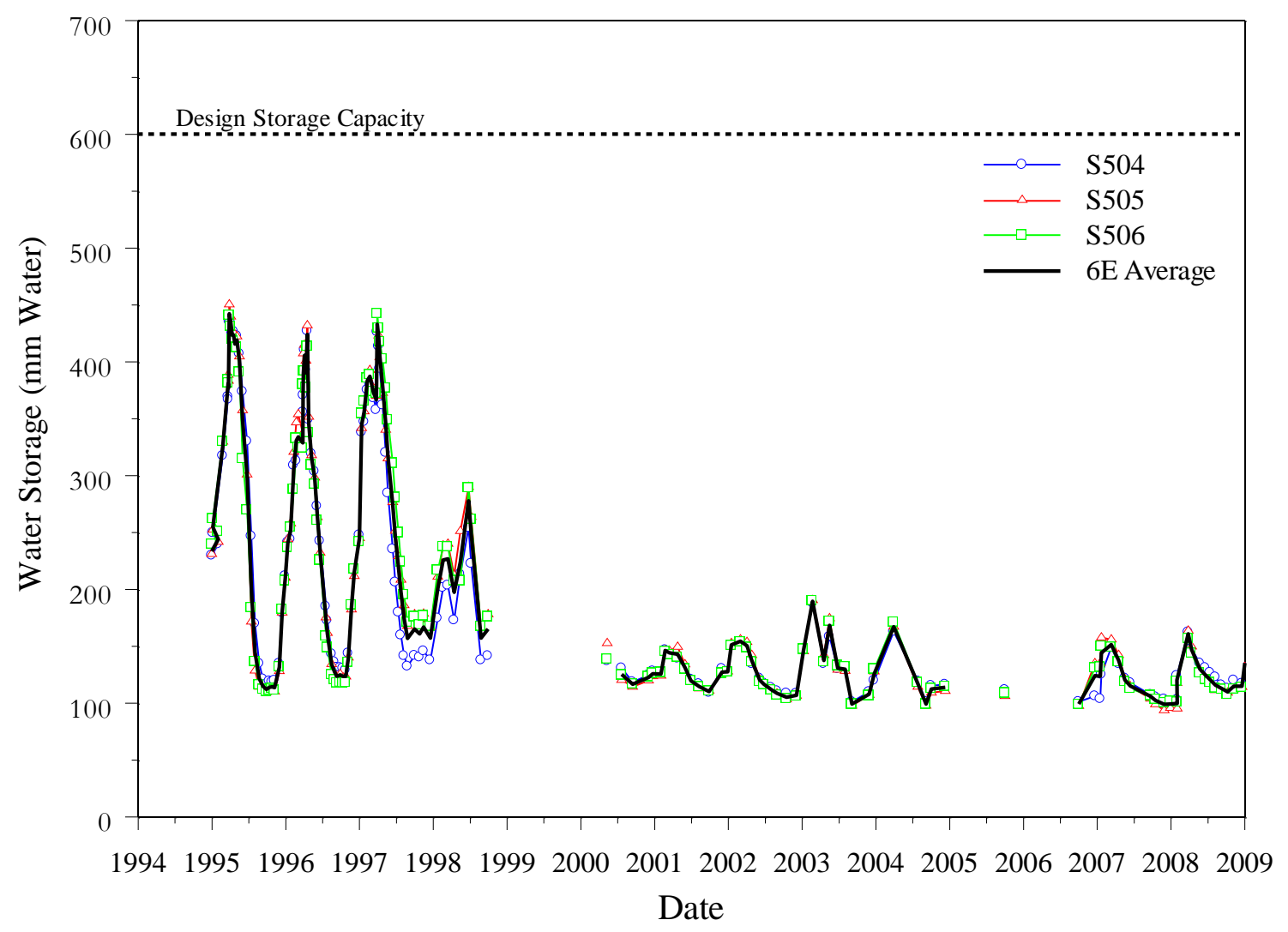

Figure 2.5. Temporal Variation in Soil-Water Storage in Northwest Plot 6E at the Prototype Hanford Barrier, October 1994 Through September 2009 (design water storage capacity is $600 \mathrm{~mm}$ ) 
Figure 2.6 shows the temporal pattern in water storage on plot $3 \mathrm{~W}$ in the southwestern quadrant of the barrier whereas Figure 2.7 shows data for plot $3 \mathrm{E}$ located in the southeastern quadrant. The temporal patterns in storage on the north and south sections of the barrier are qualitatively similar. However, the amplitudes in storage are very different, especially during the treatability test. This is expected because the south half of the barrier was not irrigated during the treatability test and has received only ambient precipitation for the last 15 years. The southern plots also show the highest storage in 2007, a direct result of the elevated precipitation in 2007. Differences in storage among the monitoring stations are evident although there is no correlation with slope position as observed on the north half of the barrier.

The annual cycle in water storage on the north and south sides is due to the evapotranspirative component of the capillary barrier. The prototype Hanford barrier is an example of capacitive barrier that uses a capillary break to enhance the water storage capacity and a fine-soil storage layer to store water and support plant growth to this recycle water. The prototype Hanford barrier has a 600-mm storage capacity and could therefore store essentially all of the cumulative precipitation over 3.75 years, assuming an annual average of $160 \mathrm{~mm} / \mathrm{yr}$. However, plants play an important role in barrier function and their role in barrier performance, particularly their impact on water storage, has been studied over the last 15 years.

Over the last 15 years, the time at which the peak in water storage occurred has ranged from as early as mid February to as late as late April. Over the last 5 years, the peak occurred around mid March. The peak was typically very short lived with a decline in storage starting almost immediately as the soil water was removed by the native vegetation. After water storage reached a record level in the winter of FY 1997, storage peaked at slightly less than $200 \mathrm{~mm}$ in 1998 for the southern plots and well above $200 \mathrm{~mm}$ for the northern plots. The winter of FY 1997 was the wettest period since barrier construction with 138.4 $\mathrm{mm}$ of precipitation recorded. The peaks in storage have since shown a consistent decline until this year. The rate of removal of water by plants appeared to depend on the precipitation treatment. During the treatability test the north side of the barrier was irrigated at a rate of three times the long-term annual precipitation and the rate of water removal was much lower than on the south section that received only ambient precipitation. On the north side, the decrease in storage typically started slightly earlier on plots S5 and S6 (Figure 2.1) than the rest of the barrier.

While the plants were able to recycle most of the applied water, the lower level of $\mathrm{W}(\mathrm{t})$ were dependent on both spatial location (slope position on surface) and time. From 1996 through 1999 the lower level of storage on the north side increased over time. This is indicative of a reduction in the efficiency of the plants to recycle water. This effect was again strongest on plots $5 \mathrm{E}$ and $6 \mathrm{E}$ in the northeastern corner of the surface where more water was retained throughout the year. The earlier start to the depletion of water storage and the larger amount of water retained at the end of the year may be related to the distribution of ground cover. These two plots have typically shown a larger cover of grass and bare ground than the rest of the barrier, a condition that has persisted through September 2008 when all vegetation was removed by a controlled burn. Owing to the shallower root system of grasses and the different growth cycle, compared to shrubs, a grass dominated system would be less effective at removing water from deep in the profile. The difference between these plots and the rest of the barrier became clearer later in the year after the wetting front migrated beyond the top $0.5-\mathrm{m}$ depth. Such a reduction in water uptake efficiency in areas dominated by grasses would contribute to a higher W(t) at the end of the summer. Nevertheless, the system showed a dramatic recovery by mid 2000. By this time, differences in the lower limit of W(t) had essentially disappeared with the values returning to those observed on the south side of the barrier (Figure 2.6 and Figure 2.7). These observations suggest that the native plant species may be quite resilient and can easily recover from short-term stresses. 


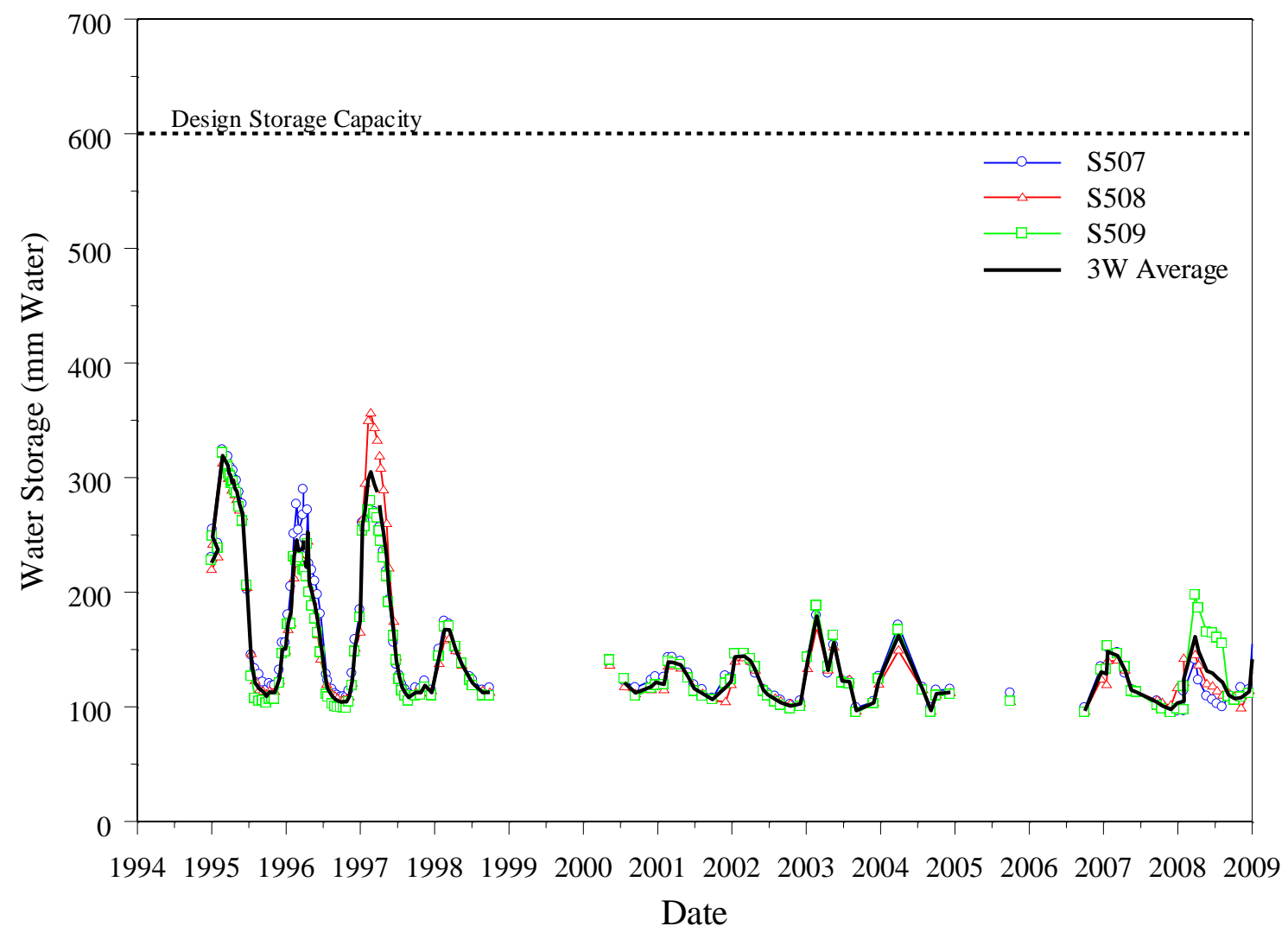

Figure 2.6. Temporal Variation in Soil-Water Storage in Northwest Plot $3 W$ at the Prototype Hanford Barrier, October 1994 Through September 2009 (design water storage capacity is $600 \mathrm{~mm}$ ) 


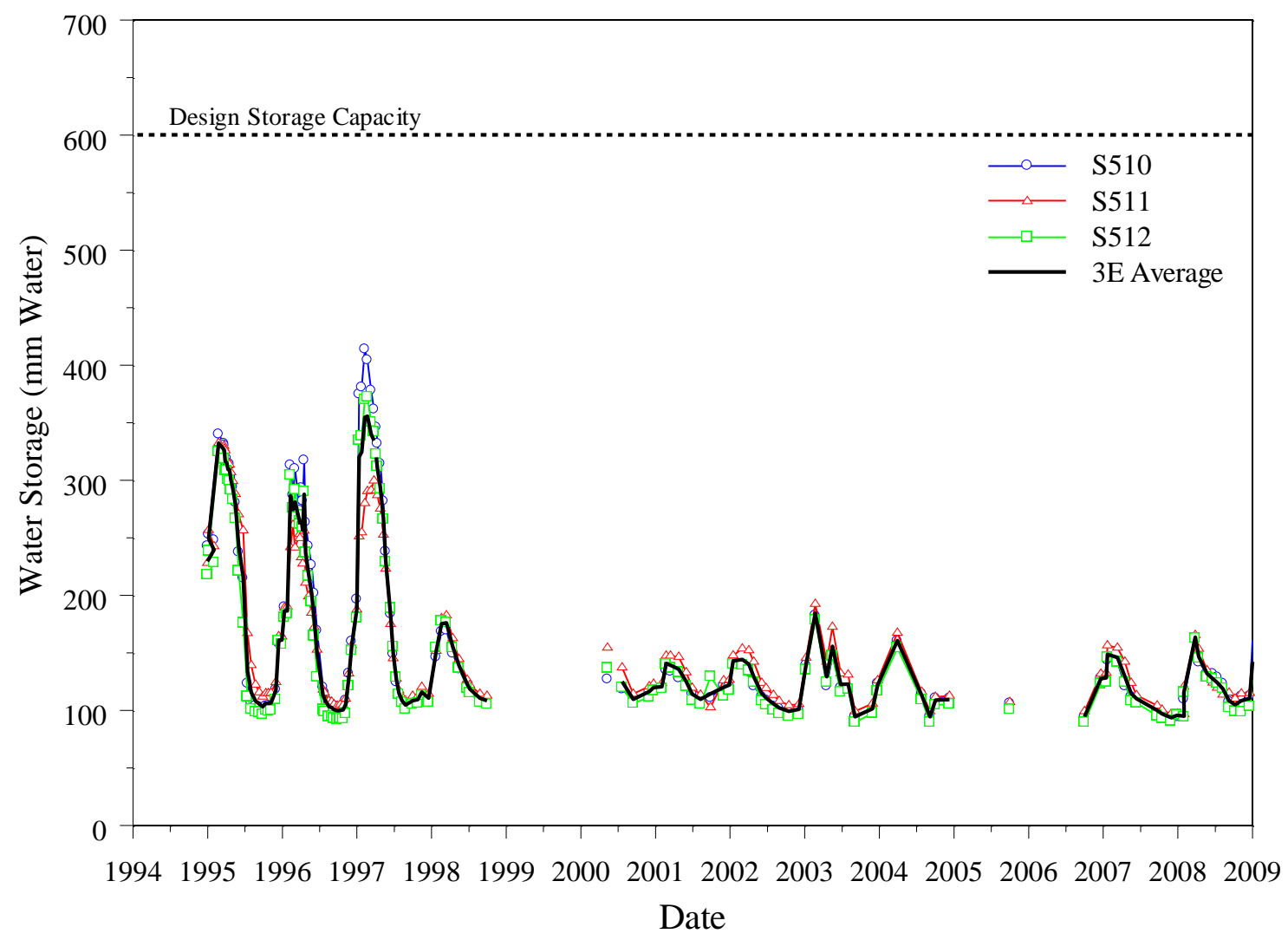

Figure 2.7. Temporal Variation in Soil-Water Storage in Northwest Plot 3E at the Prototype Hanford Barrier, October 1994 Through September 2009 (design water storage capacity is $600 \mathrm{~mm}$ ) 
Figure 2.8 compares the mean storage on the north and south sections of the barrier. The mean storage for the north was calculated as the temporal average of W(t) measured at S1 through S6. The mean storage for the south was calculated as the temporal average of $\mathrm{W}(\mathrm{t})$ measured at $\mathrm{S} 7$ through $\mathrm{S} 12$. Over the last 15 years, mean $\mathrm{W}(\mathrm{t})$ has ranged from $97 \mathrm{~mm}$ to $438 \mathrm{~mm}$ with a standard deviation of $103 \mathrm{~mm}$. Over the same period, $\mathrm{W}(\mathrm{t})$ on the south section has ranged from $95 \mathrm{~mm}$ to $330 \mathrm{~mm}$ with a standard deviation of $69 \mathrm{~mm}$. The storage data also show that since the completion of the treatability test, the once-prominent peaks have shown a progressive decline over time except for the last two years. In the 4 years following the treatability test, mean storage rarely exceeded $150 \mathrm{~mm}$. In 2003, peak storage was closer to $200 \mathrm{~mm}$, and in 2004, the peak was around $167 \mathrm{~mm}$. This increase in peak storage over the last two years is a direct consequence of changes in precipitation and its seasonal distribution. The divergence in the lower limits of storage is also quite clear in the plot of mean storage. In the early stages of testing, the lower limits of storage between monitoring stations were quite similar but gradually diverged until 1999. This deviation has been attributed to interplot differences in the ability of the vegetation to recycle applied water. In FY2008, mean W(t) ranged from $97 \mathrm{~mm}$ to $162.2 \mathrm{~mm}$ with a standard deviation of $21.6 \mathrm{~mm}$ on the north. For the same period, mean $\mathrm{W}(\mathrm{t})$ ranged from $96 \mathrm{~mm}$ to $162.4 \mathrm{~mm}$ with a standard deviation of $21.5 \mathrm{~m}$ on the south side. These results show that the divergence in the lower values of storage on the north and south sections, prominent during and immediately after the treatability test, has essentially disappeared. These results confirm the hypothesis that the differences in the lower limit of water withdrawal may have developed as a result of stresses caused by irrigation. The disappearance of these differences is an important observation and suggests that the native species can easily recover from relatively short-term stresses. In this case, increased stress was present for 5 years and may have been caused by elevated precipitation on the irrigated treatments over the 3-yr treatability test. Effects of this imposed stress persisted for about two years after irrigation ceased.

The optimal design of a barrier requires close attention to the choice of plant species and may require some maintenance to ensure that the right mix of plant species remains active. A controlled burn in FY 2008 was used to remove all of the vegetation from the north side of the barrier and this has already impacted the water storage patterns. During the last year (FY2009), mean W(t) ranged from $110 \mathrm{~mm}$ to $157 \mathrm{~mm}$ with a standard deviation of $17.6 \mathrm{~mm}$ on the north. For the same period, mean $\mathrm{W}(\mathrm{t})$ ranged from $100 \mathrm{~mm}$ to $169 \mathrm{~mm}$ with a standard deviation of $25 \mathrm{~m}$ on the south side as described in the next section.

\subsubsection{Effects of Fire on Soil-Water Storage}

Vegetation on the north side was removed by a controlled burn on September 26, 2008 and this is reflected in differences in the water content profiles and water storage between the north and south sections (Figure 2.9). A comparison of the soil water profiles measured on the north and south sections show significant differences that can be directly attributed to the fire. In September 2008, just before the fire, the soil water storage is almost all depleted and the north and south sides showed no differences in water content distributions. By January 2009, after a relatively wet winter, a difference in the water content profiles can be seen between the north and south sections with the south section being considerably wetter in the top $0.7 \mathrm{~m}$ and with the north section showing slightly wetter conditions at depth $(0.8$ to $1.6 \mathrm{~m})$. With both sides receiving the same amount of precipitation, the difference in water content distribution is due to changes induced by the fire, although discrepancy is somewhat counter intuitive. The lower near-surface water content can be attributed to increased evaporation from the bare surface whereas the developing moisture front at depth is due to redistribution of water that moved beyond the evaporative depth. The wetting front developing at depth is more obvious in the February 2009 and subsequent profiles. 


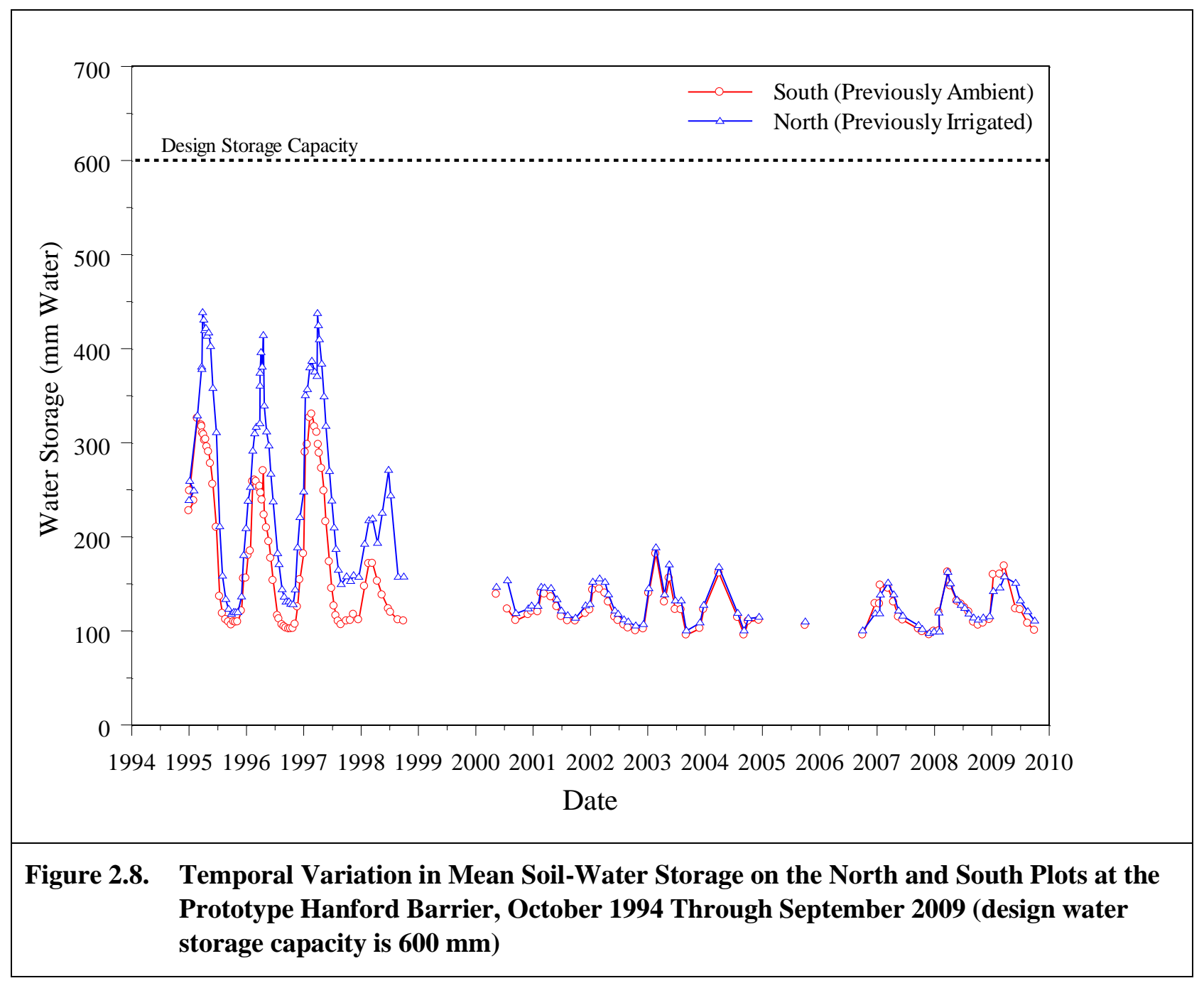




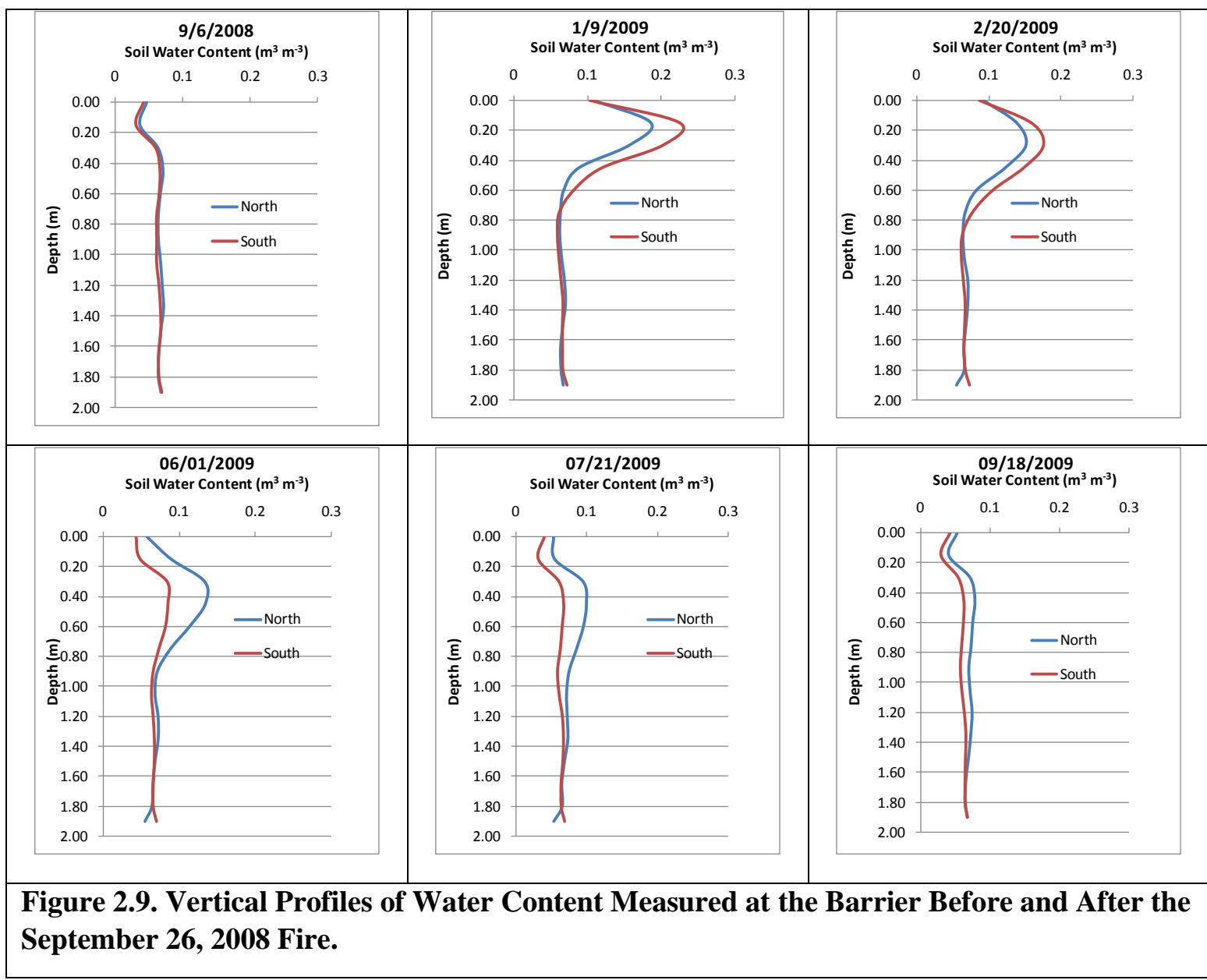


After the start of spring, the depletion in moisture content owing to plant uptake increased and there was a sharp reduction of moisture in the 0 to $0.8 \mathrm{~m}$ depth on the south side whereas water content at depth continued to increase. The rapid decrease in the top $0.8 \mathrm{~m}$ is likely due to uptake by grasses that broke hibernation early. By June, the profiles had reversed with the burned section being considerably wetter than the unburned section with the leading edge of the wetting front persisting at depth. By July the difference between the burned and unburned sections was much smaller although the burned section was still wetter. Owing the relatively low ground cover on the recovering burned section and the relatively small plants, it is likely that evaporation was the dominant mechanism for storage depletion. More importantly, the evaporative depth appears to extend much deeper than the top few centimeters that is typically assumed in uncoupled models for predicting water balance processes.

Temporal distribution in water storage was calculated to determine whether there were differences between the burned (north) and unburned (south) sections. Temporal distributions in water storage following the fire are shown in Figure 2.12. Both the north and south sections show the characteristic cycle in storage with relatively small inter-plot differences but significant differences between the two sides. Both the north and south plots started of at essentially the same level of water storage just prior to the fire. As in previous years, plot $6 \mathrm{E}$ showed a slightly higher storage that persisted through the year. Water storage decreased through October 2008 and started to increase again in November 2008, reaching a peak in mid March 2009. Differences in W(t) between the two sides are more obvious in Figure $2.12 \mathrm{c}, \mathrm{d}$. The north and south plots started at essentially the same $\mathrm{W}(\mathrm{t})$ prior to the fire and showed the same rate of depletion immediately after the fire. However, the rate of water loss declined on the burned (north) section after October 2008 resulting in a larger amount of water being retained. A sharp increase in $\mathrm{W}(\mathrm{t})$ occurred in December 2008 with both the burned and unburned sections reaching a peak in March 2009. However the rate of increase in storage is significantly higher on the unburned section than on the burned section and so is the peak storage attained. These differences can be attributed to the two relative contributions of evaporation and transpiration to soil water depletion. On the burned section, water loss would have been entirely by evaporation whereas both evaporation and transpiration would have contributed to water loss on the unburned section. These data suggest that there was significant water loss from the burned section over winter due to evaporation and this resulted in a slower rate of increase in storage and a lower peak value.

On the unburned section, higher ground cover and the shrub canopy reduced the effects of evaporation and owing to the plants being in hibernation, plant water uptake was near zero. Thus, $\mathrm{W}(\mathrm{t})$ on the unburned section increased faster and reach a higher peak amount. With the arrival of warmer temperatures the trend was reversed as transpiration started on the unburned plots. Evapotranspiration increased the rate of water loss above that of the burned section where the dominant mechanism was evaporation. The result was a sharper decline in $\mathrm{W}(\mathrm{t})$ on the unburned section than on the burned section. This observation of large evaporation rates is consistent with finding of Fayer and Gee (2006) who reported significant evaporation from similar soils in a variety of barrier designs at Hanford's field lysimeter test facility (FLTF). Plant surveys in August and September 2009 show that one year after the fire, plant species richness increased from 10 to 15 on the unburned half of the surface and increased markedly to 24 species on the burned half. However, there is a significant difference in ground cover with the burned half showing $80 \%$ bare soil compared to $25 \%$ on the unburned half. Despite the loss of plants from the burned section, water storage on at the end of September 2009 was quite similar on the burned $(110 \mathrm{~mm})$ and unburned $(100 \mathrm{~mm})$ sections. It is still likely that continued evaporation from the burned section between now and the onset of winter precipitation could further reduce the stored water. 


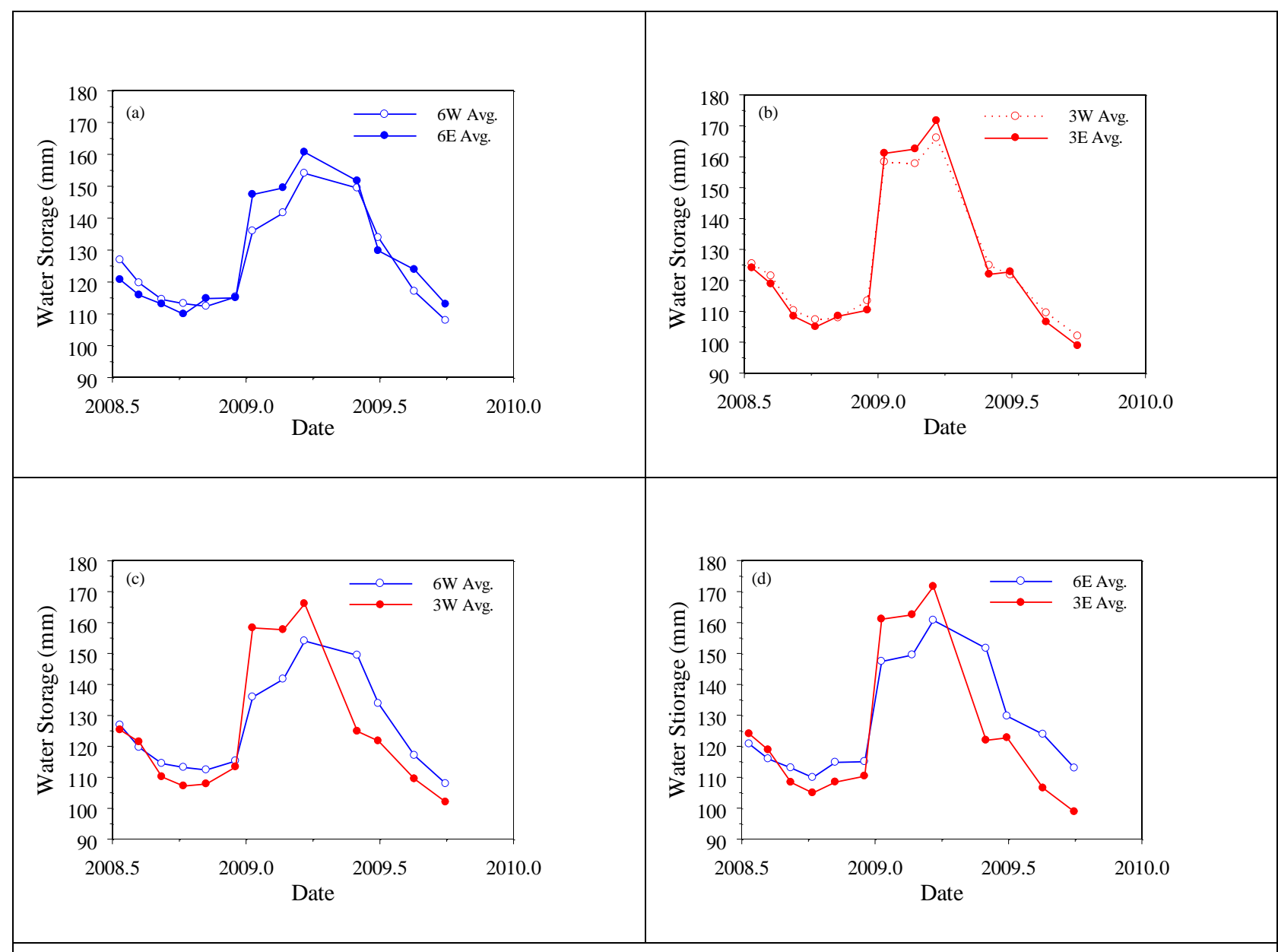

Figure 2.10. Post-fire Average Water Storage at the Barrier, (a) North Plots, (b) South Plots, (c) Northwest and Southwest Plots, and (d) Northeast and Southeast Plots. 


\subsubsection{Drainage}

Any water passing through the soil and rock layers is intercepted by asphalt layer and diverted to a collection system. This water is treated as drainage in the water balance equation. Drainage is monitored using a combination of tipping buckets, for low flows, and pressure transducers with data recorded at hourly intervals. Data have collected on a nearly continuous basis since 1994, except for a 3-month hiatus in FY 1999 that was the result of datalogger failure. The total drainage values for this period were estimated from manual dose counters installed on the siphons and by interpolation between FY 1998 and FY 2000. Table 2.3 and Table 2.4 summarize the drainage amounts from the eight main drainage collection areas on the barrier for October 1994 through August 2009.

Table 2.3. Amounts of Water Diverted by the Asphalt Pad (Drainage) from the North Plots at the Prototype Hanford Barrier and the Relationship to Barrier Precipitation

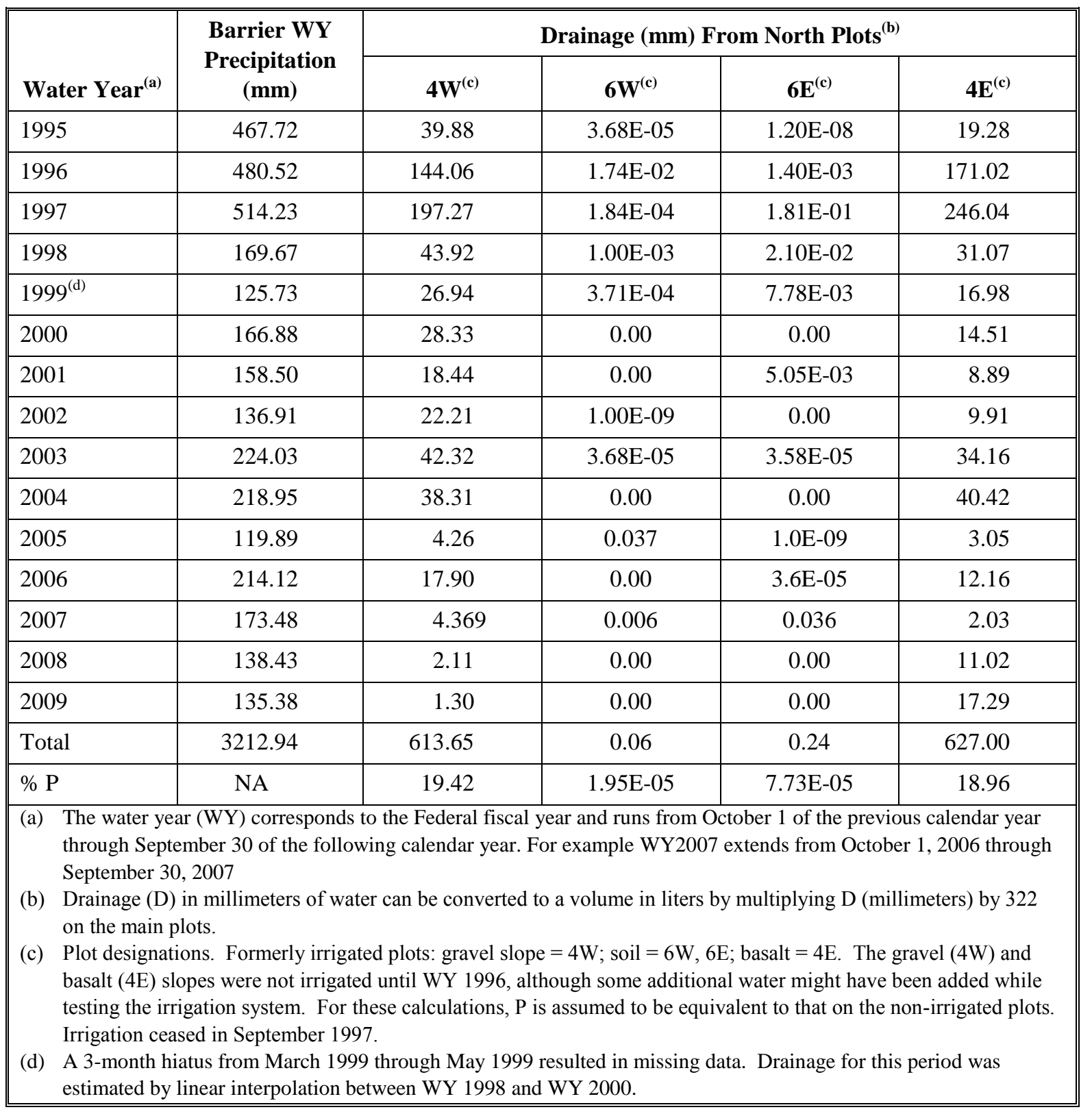


Table 2.4. Amounts of Water Diverted by the Asphalt Pad (Drainage) from the South Plots at the Prototype Hanford Barrier and the Relationship to Barrier Precipitation

\begin{tabular}{|c|c|c|c|c|c|}
\hline \multirow[b]{2}{*}{ Water Year ${ }^{(a)}$} & \multirow{2}{*}{$\begin{array}{l}\text { Barrier WY } \\
\text { Precipitation } \\
(\mathbf{m m})\end{array}$} & \multicolumn{4}{|c|}{ Drainage $(\mathrm{mm})$ From South Plots ${ }^{(\mathbf{b})}$} \\
\hline & & $1 W^{(c)}$ & $3 \mathbf{W}^{(\mathbf{c})}$ & $3 \mathbf{E}^{(\mathbf{c})}$ & $1 \mathbf{E}^{(\mathrm{c})}$ \\
\hline 1995 & 280.67 & 24.67 & $3.26 \mathrm{E}-05$ & $2.01 \mathrm{E}-02$ & 3.43 \\
\hline 1996 & 233.17 & 70.07 & $3.26 \mathrm{E}-05$ & $6.75 \mathrm{E}-02$ & 58.52 \\
\hline 1997 & 289.31 & 156.48 & $2.28 \mathrm{E}-04$ & $1.80 \mathrm{E}-04$ & 123.31 \\
\hline 1998 & 169.67 & 28.56 & 0.00 & 0.00 & 15.72 \\
\hline $1999^{(d)}$ & 125.73 & 15.43 & 0.00 & 0.00 & 0.00 \\
\hline 2000 & 166.88 & 12.86 & 0.00 & 0.00 & 11.08 \\
\hline 2001 & 158.50 & 15.18 & 0.00 & 0.00 & 9.20 \\
\hline 2002 & 136.91 & 11.06 & 0.00 & 0.00 & 7.45 \\
\hline 2003 & 224.03 & 25.37 & 0.00 & $3.60 \mathrm{E}-05$ & 29.82 \\
\hline 2004 & 218.95 & 26.77 & 0.00 & 0.00 & 33.26 \\
\hline 2005 & 119.89 & 2.69 & 0.03 & 0.04 & 2.29 \\
\hline 2006 & 214.12 & 10.75 & 0.00 & 0.00 & 0.18 \\
\hline 2007 & 173.48 & 0.18 & 0.00 & 0.00 & 0.10 \\
\hline 2008 & 138.43 & 0.00 & 0.00 & 0.00 & 9.04 \\
\hline 2009 & 135.38 & 0.00 & 0.00 & 0.00 & 13.18 \\
\hline Total & 2771.90 & 388.49 & 0.03 & 0.12 & 321.25 \\
\hline$\% \mathrm{P}$ & NA & 14.71 & $1.47 \mathrm{E}-05$ & $4.40 \mathrm{E}-03$ & 11.50 \\
\hline $\begin{array}{l}\text { (a) The water ye } \\
\text { through Sept } \\
\text { September } 3 \\
\text { (b) Drainage (D } \\
\text { on the main } \\
\text { (c) Plot designa } \\
\text { (d) A 3-month h }\end{array}$ & $\begin{array}{l}\text { (WY) correspond } \\
\text { ber } 30 \text { of the foll } \\
2007 . \\
\text { millimeters of w } \\
\text { ts. } \\
\text { as. Formerly unir } \\
\text { us from March } 19\end{array}$ & $\begin{array}{l}\text { e Federal f } \\
\text { calendar y }\end{array}$ & $\begin{array}{l}\text { and runs fro } \\
\text { xample WY2 } \\
\text { volume in lit } \\
=1 \mathrm{~W} \text {; soil = } \\
\text { lted in missi } \\
\text { Y } 2000 \text {. }\end{array}$ & $\begin{array}{l}\text { er } 1 \text { of the } \mathrm{p} \\
\text { ends from } \mathrm{O} \\
\text { ultiplying } \mathrm{D} \\
\text {; basalt }=1 \mathrm{E} \\
\text { Drainage fo }\end{array}$ & $\begin{array}{l}\text { alendar year } \\
2006 \text { through } \\
\text { ters) by } 322 \\
\text { iod was }\end{array}$ \\
\hline
\end{tabular}

The drainage data show significant differences between precipitation treatments as well as within treatments from year to year. Both the north riprap and gravel covered slopes show similar totals for the monitored period (Table 2.3). However, there is a significant difference in drainage between the south gravel and riprap slopes (Table 2.4). Differences in total drainage between the north and south slopes are due to the differences in precipitation amounts during the treatability test. During the 3-yr treatability test, the north plots were irrigated whereas the south plots were maintained under ambient precipitation conditions. Figure 2.11 provides a graphical summary of the rate of drainage from the side-slope plots for the monitored period. Figure 2.12 provides a similar plot for rate of drainage from the silt-loam plots. 


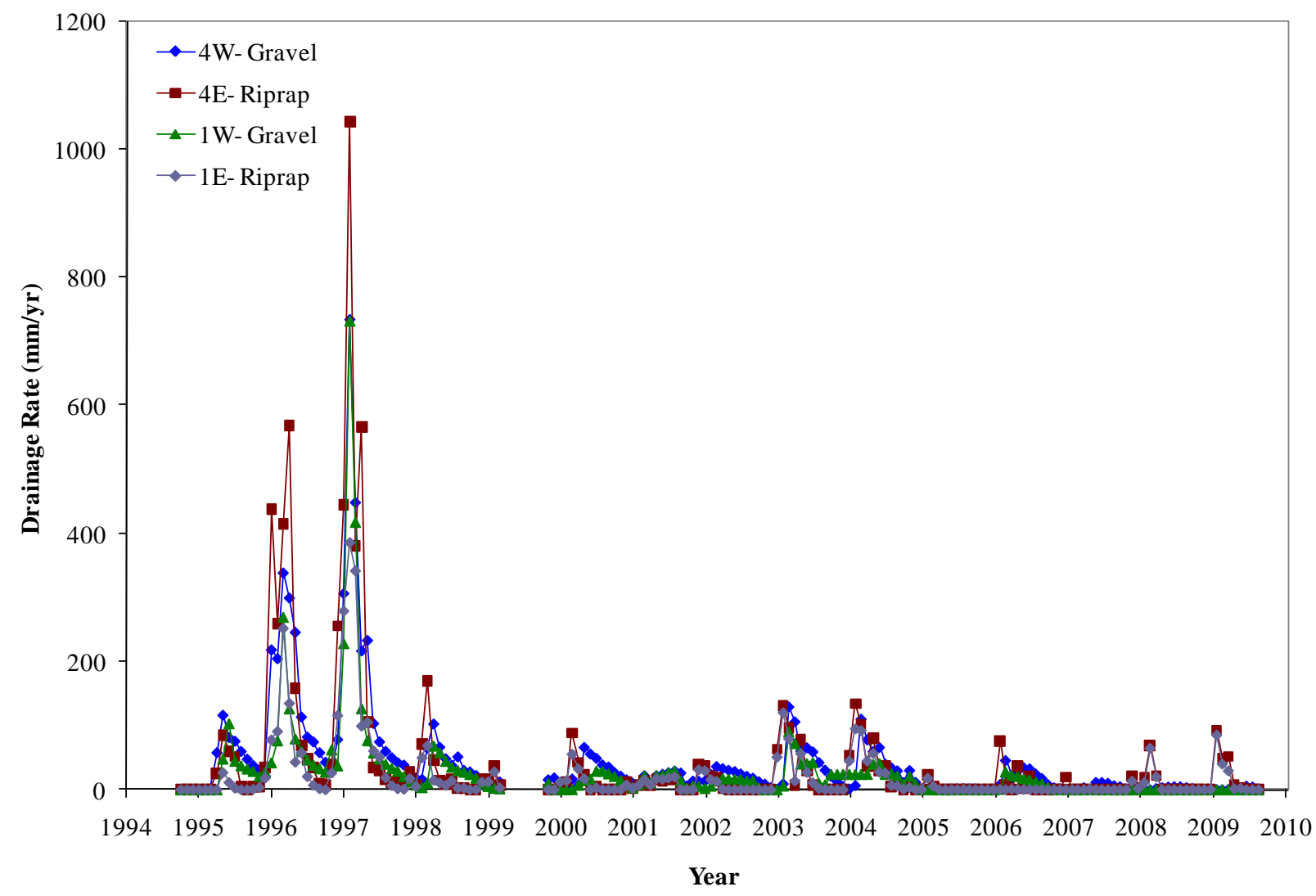

Figure 2.11. Rate of Drainage from the Side-slope Plots at the Prototype Hanford Barrier for the Period September 1994 Through August 2009. 


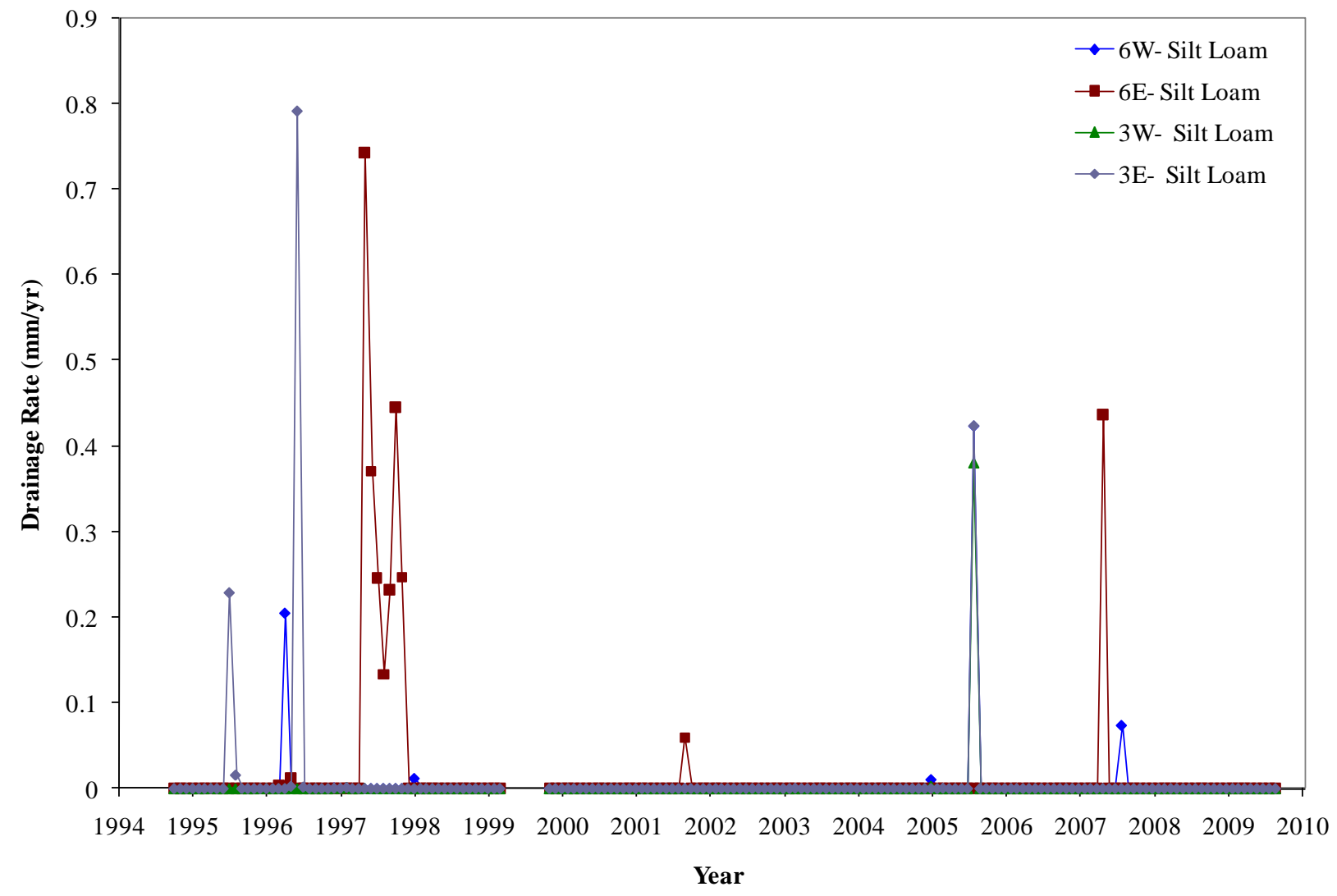

Figure 2.12. Rate of Drainage from the Silt-loam Plots at the Prototype Hanford Barrier for the Period September 1994 Through August 2009. 
These rates can be considered as equivalent rates as they are computed by converting the total drainage collected over a period of one month to an equivalent rate in $\mathrm{mm} / \mathrm{yr}$. Equivalent drainage rates were typically at their highest during the winter months. However, rates from the side slopes were significantly higher than from the silt-loam plots. Drainage from the side slope reached a maximum rate in excess of $1000 \mathrm{~mm} / \mathrm{yr}$ in the winter of FY 1997. Drainage rates from the silt-loam plots also peaked in the winter months but the values were several orders of magnitude smaller. The highest equivalent rate from the silt loam was $0.79 \mathrm{~mm} / \mathrm{yr}$, recorded from $3 \mathrm{~W}$ in FY 1996. These rates would have been of very short durations. However, a more complete picture of drainage performance can be derived from a comparison of cumulative drainage amounts.

Figure 2.13 shows the cumulative drainage from the side-slope plots for the period from October 1994 through August 2009. Figure 2.14 shows a similar plot for the soil-covered plots. Since the start of testing, drainage from the barrier has shown seasonal dependence. Of the side slope plots, the irrigated riprap treatments typically showed lower drainage rates than the gravel except in the winter months. Despite the low rates in the summer, cumulative drainage from the riprap generally exceeded that from the gravel for the duration of the treatability test. This is because drainage rates from the riprap were usually much higher than from the gravel in the winter months. Differences between the gravel and riprap on the north plots started to decline after reaching a maximum in the winter of FY 1997, becoming almost identical by the end of FY 2002.

Since then, the drainage rates from the gravel have been increasing relative to the rates for riprap. By the end of August 2009, the north gravel slope (4W) had drained $611.1 \mathrm{~mm}$ or $17.8 \%$ of the intercepted precipitation whereas the north riprap slope (4E) had drained $627.29 \mathrm{~mm}$ or $18.3 \%$ of the intercepted precipitation. However, there is a significant difference in drainage between the south gravel and riprap slopes. The effects of side slope configuration are complicated by the use of irrigation during the treatability test. However, these effects are absent on the south side slopes and the results are more amenable to interpretation. On the southern plots, drainage from the gravel slope (1W) consistently exceeded that from the riprap (1E). These differences have persisted throughout the monitoring period (Figure 2.13). By the end of August 2009, cumulative drainage from the un-irrigated gravel was 388.5 $\mathrm{mm}$, or $14.1 \%$ of total precipitation, whereas the south riprap slope (1E) had drained $321.2 \mathrm{~mm}$, or $11.6 \%$ of intercepted precipitation. This represents a difference of $67 \mathrm{~mm}$, but this difference appears to be declining over time, from over $90 \mathrm{~mm}$ in the early stage of monitoring to $80 \mathrm{~mm}$ in FY 2008.

The discrepancy in drainage from the two side slope configurations, exposed to the same meteorological conditions, is due to the effects of advective drying. Wind pumping with air of low relative humidity causes evaporation of moisture from the rip rap surfaces thereby reducing drainage from the riprap slopes.

Nonetheless, these results also show that through FY 2009, cumulative drainage from each of the soilcovered plots remained significantly less than the $0.5 \mathrm{~mm} \mathrm{yr}^{-1}$ drainage criterion (Figure 2.14). Plots 6W, $3 \mathrm{~W}, 3 \mathrm{E}$, and $6 \mathrm{E}$ generated totals of $0.062 \mathrm{~mm}, 0.033 \mathrm{~mm}, 0.124 \mathrm{~mm}$, and $0.244 \mathrm{~mm}$ of drainage, respectively, over the 15 -yr period. There has always been some uncertainty about the nature of the higher amounts from plot 6E. Verification studies in FY 1997 showed no significant differences in soil physical properties. However, visual inspection and vegetation surveys suggest a significant difference in the composition of ground cover on this plot with a larger percentage of grass and smaller than average shrubs (Section 4). Given that the 600-mm storage capacity of the 2-m thick silt loam layer has never been exceeded, the observed small amounts of drainage may be related to thermal effects exacerbated by differences in vegetative cover. Nonetheless, the mean drainage from the soil plots over the $15-\mathrm{yr}$ monitoring period is only $0.116 \mathrm{~mm}$ with a standard deviation of $0.093 \mathrm{~mm}$. This is equivalent to a 


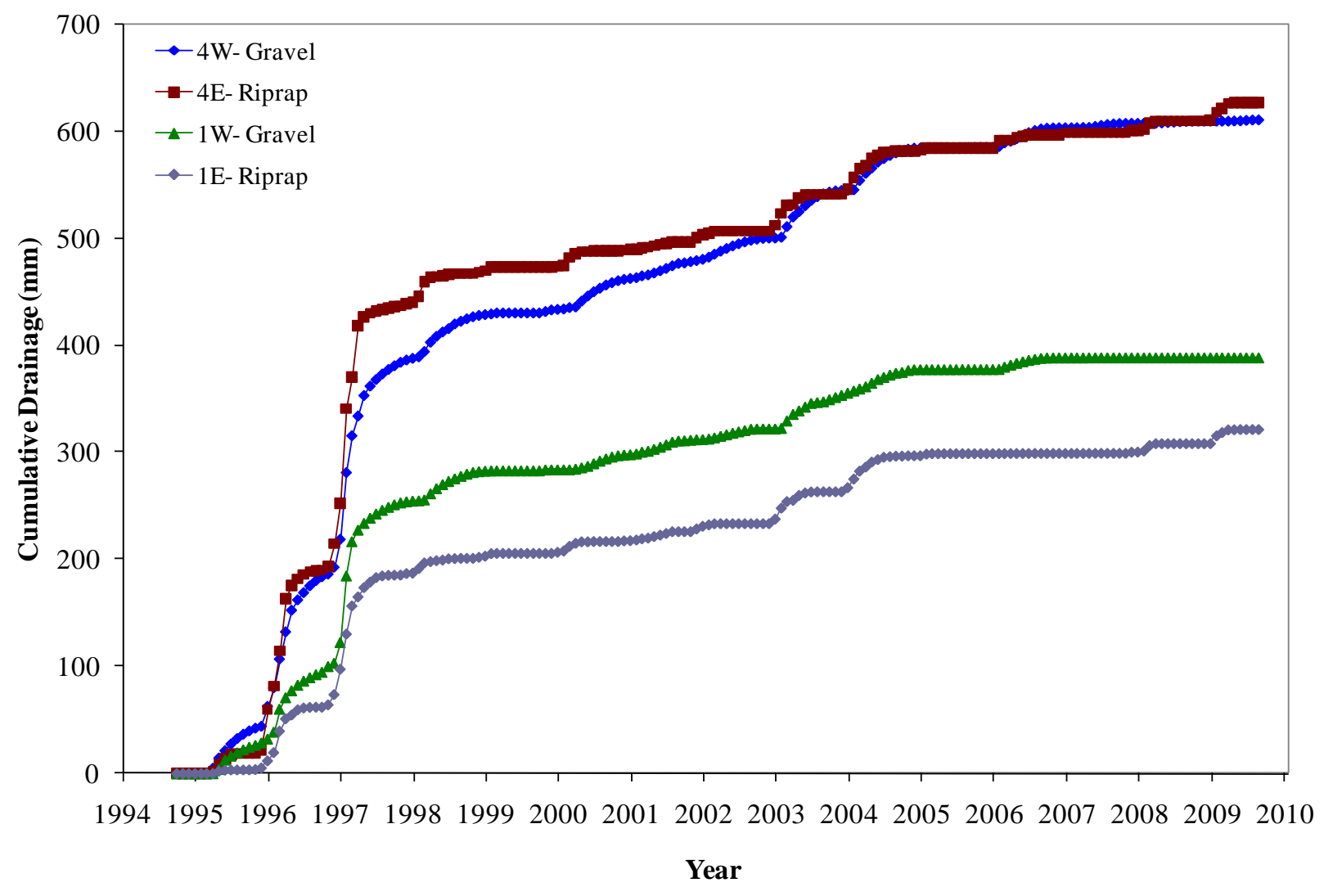

Figure 2.13. Cumulative Amounts of Water Diverted by the Asphalt Pad (Drainage) from the SideSlope Plots at the Prototype Hanford Barrier in September 1994 Through August 2009. 


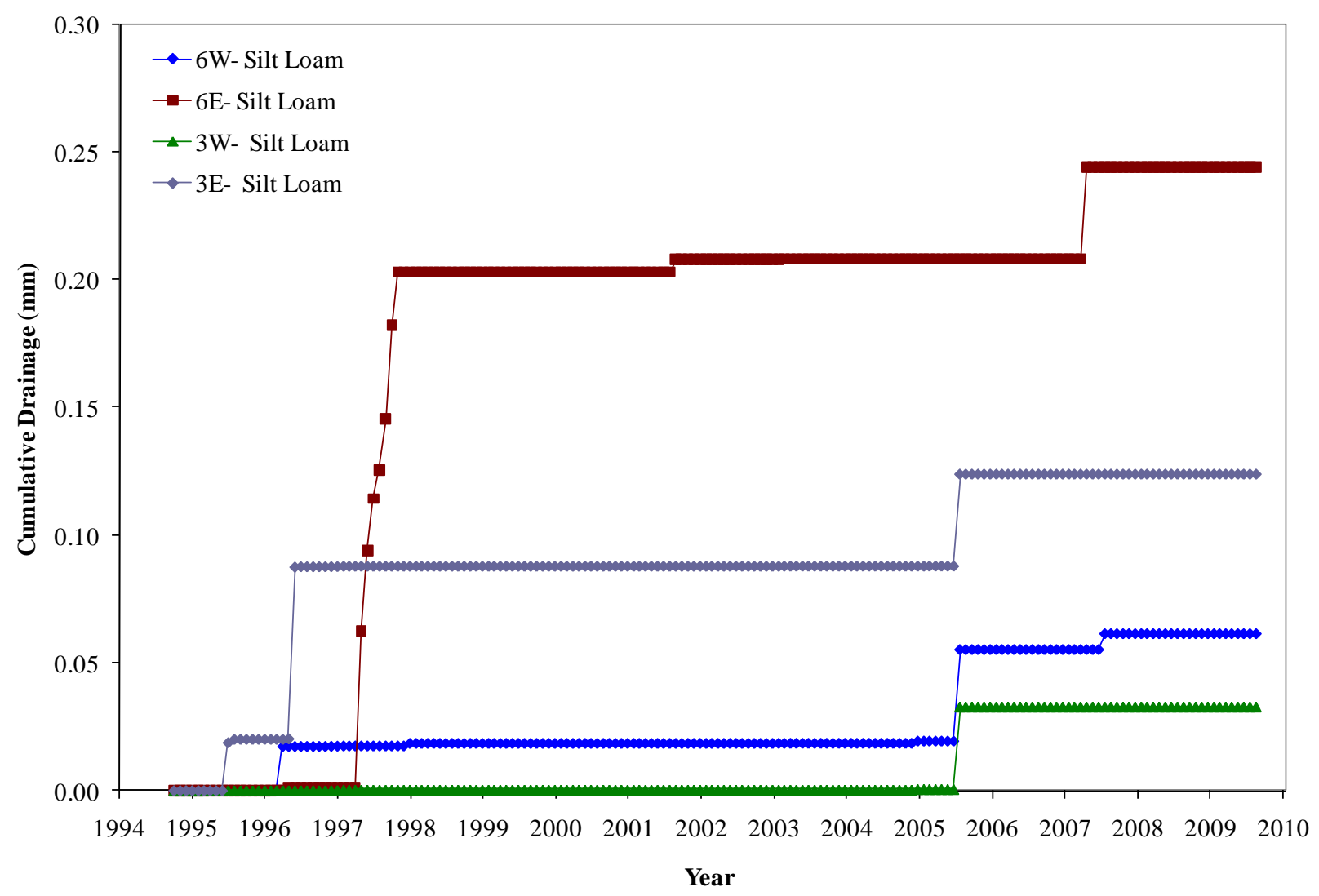

Figure 2.14. Cumulative Amounts of Water Diverted by the Asphalt Pad (Drainage) from the Silt Loam Plots at the Prototype Hanford Barrier in September 1994 Through August 2009. 
percolation rate of only $0.0075 \mathrm{~mm} / \mathrm{yr}$ or $1.5 \%$ of the annual drainage criterion of $0.5 \mathrm{~mm}$. These results clearly illustrate the effectiveness of the capacitive barriers constructed of fine soil materials in minimizing percolation. The 2 -m thick silt-loam cover essentially cut off percolation as these small amounts of water collected from under the silt loam has been attributed to condensation in the drainage system. Even at this low rate, none of this water would contribute to recharge as the prototype barrier includes low-permeability asphalt layer at its base.

Figure 2.15 shows a grouped bar graph of cumulative drainage for FY 1995 through FY 2009. This plot shows that with the exception of FY 1997, the wettest year on record for the barrier, the north gravel plot (4W) has consistently drained a larger fraction of precipitation that any of the other plots. Equivalent drainage rates (e.g. Figure 2.11 and Figure 2.12) show a strong correlation between drainage rates and winter precipitation. However, the higher rates observed from plot $4 \mathrm{~W}$ through 2007 remain unexplained. It was initially hypothesized that the larger drainage was due to a leak in the irrigation supply system. Such a leak was found and fixed in the FY 2002 and since then, the water supply to the barrier has been shut off. If the higher drainage had been caused by a water line leak then differences between $4 \mathrm{~W}$ and other plots, with a similar configuration (e.g. 1W) would have been eliminated after FY 2002. As shown in Figure 2.15 these differences continued through FY 2007. One possible explanation is a difference in the hydraulic properties of the north section of the gravel slope. Small differences in the particle size distribution between $4 \mathrm{~W}$ and on $1 \mathrm{~W}$ could impact on the water holding capacity. Another explanation could be differences in plant cover between the two gravel plots. A lower plant density on the northwestern plot would result in lower drainage amounts compared to the southwestern plot. A lower plant density on $4 \mathrm{~W}$ would result in less water loss by evapotranspiration and an increase in drainage relative to $1 \mathrm{~W}$. However, the FY 2007 plant survey found that percent cover on the north and west side slopes was relatively uniform so the data were combined. Nonetheless, drainage from $4 \mathrm{~W}$ as a percentage of precipitation has shown a steady decline since FY 2002 compared to 4E. In 2008 and 2009, drainage from the riprap slopes exceeded drainage from the gravel slopes for the first time since 2004. This can be attributed to a change in the seasonal distribution of precipitation. Total precipitation was much higher in $2004(218.95 \mathrm{~mm})$ than in 2008 and 2009 but the percentage that occurred in the winter of $2004(57 \%)$ was quite similar to that in 2008 (43\%) and 2009 (51\%) compared to other years and the normal $37 \%$.

\subsubsection{Surface Runoff and Erosion}

Monitoring of runoff continued in through FY 2009. Over the last 15 years, there have been only three runoff events. The first event occurred during the first simulated 1000 year storm event in March 1995. This was shortly after barrier construction at a time when vegetative cover was minimal. During that event, about $2 \mathrm{~mm}$ ( $2 \%$ of applied precipitation) of runoff was recorded.

The second event occurred during the winter of 1997 when $36.3 \mathrm{~mm}$ of runoff was measured. This amount was attributed to a rapid snowmelt on frozen ground. No erosion was observed. The most recent runoff event occurred from the north plot in January of 2009. This event was precipitated by the removal of vegetation from north half of the barrier occurred after the precipitated by the removal of

In May 2004, after severe thunderstorms, water collecting near the BY Farm eroded a berm and flowed down the north-western slope of the tank farm, eroding gravel armor in its path. The runoff water from the elevated BY-BX Tank Farm surface flowed down-gradient to the region between the tank farm and the prototype barrier, damaging the west fence and eroding a channel over 40-inches deep at the base of 


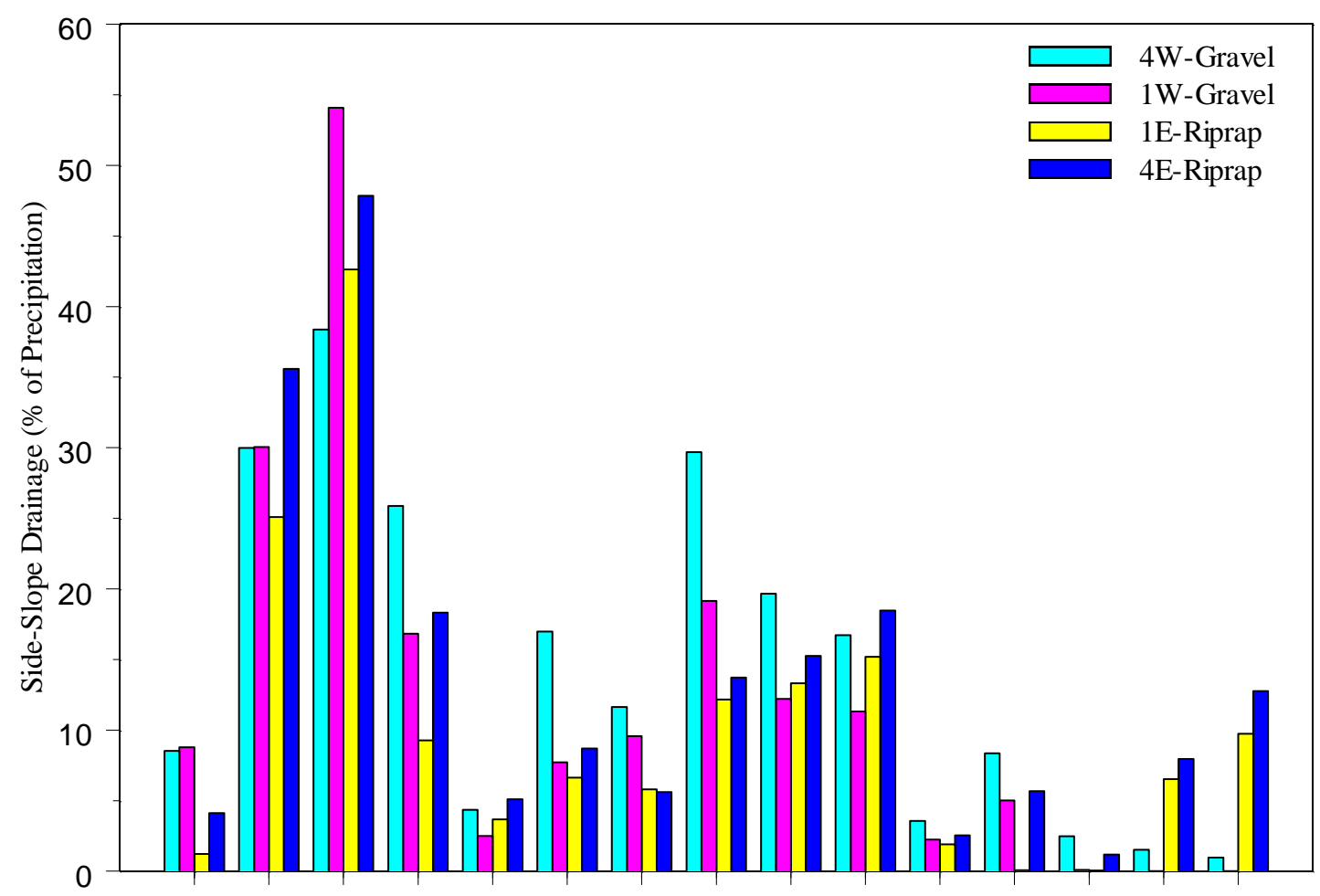

199519961997199819992000200120022003200420052006200720082009

Year

Figure 2.15. Cumulative Amounts of Water by Water Year Diverted by the Asphalt Pad (Drainage) From the Side-Slope Plots at the Prototype Hanford Barrier in September 1994 Through August 2009 as a Percentage of Precipitation. 
the barrier side slope. Although rain storms of similar magnitude have since occurred, there is no evidence of further runoff or erosion.

In January 2009, following the controlled burn of the north section of the barrier, a total of 1.6 liters of runoff was recorded. This is equivalent to $0.016 \mathrm{~mm}$, quite small compared to previous events but the first observed in over 15 years and can be attributed directly to the effects of the fire

\subsubsection{Deep Percolation}

The barrier includes an asphaltic concrete layer at the base so any water that passes through the fine-soil layers is diverted for measurement and discharge north of the barrier. In situ measurements of the hydraulic conductivity by a falling head method gave a mean of $3.66 \times 10^{-8} \mathrm{~cm} / \mathrm{s}$ where as core measurements averaged $1.29 \times 10^{-8} \mathrm{~cm} / \mathrm{s}$. Measurements made on the fluid applied asphalt membrane installed on top of the asphaltic concrete layer show an even lower conductivity of less than $1 \times 10^{-11} \mathrm{~cm} / \mathrm{s}$ (Freeman et al. 1994). Thus, percolation through this layer, if it occurs, will be at a very slow rate.

Indication of deep percolation is derived from measurements of soil water content at the depth of the capillary break and under the asphalt layer in horizontal neutron access tubes and monitoring drainage into an under-asphalt lysimeter located in the northeastern corner of the barrier. After 15 years, there is no evidence of percolation through the asphalt layer from the pan lysimeter.

Figure 2.16 compares plots of volumetric water content, $\theta$, as a function of space and time on the northern (previously irrigated) half of the barrier (neutron tubes AA1 + AA5 and AA2 + AA6) from December 1994 through September 2009. Figure 2.17 shows similar plots for the southern, non-irrigated section (AA3 and AA4). These plots represent water content measured to within $1 \mathrm{~m}$ of the barrier crown in the $\mathrm{u}$-shaped tubes just above the capillary break. The $\mathrm{x}$-axis represents horizontal distance from the crown of the barrier with a positive ordinate representing to the east of center (toward the riprap side slope) and a negative ordinate to the west of center (toward the gravel side slope). Shortly after construction, water content variations showed strong spatial and temporal pattern at the capillary break. Water content typically increased in the winter, reaching a maximum in late spring, and decreased over the summer. On the southern half of the barrier, water content decreased within the first few months of surface revegetation and remained unchanged throughout most of the test period. This overall trend showed a dramatic change in 1997 when infiltration became focused along the edges, as observed in the northern section. Water content at the capillary break has shown a steady decline over the last several years with a sharp drop in 2005 but shows no evidence of seasonal cycling.

Apart from the short-term changes in moisture observed during the early stages of the treatability test, moisture content has remained unchanged or declined. There is also no evidence of water penetration along the edges. Both the north and south plots show that the greatest accumulation of water occurred during periods of elevated precipitation. This accumulation occurred under the transition surface plots ( $5 \mathrm{~W}$ and $5 \mathrm{E}$ ) of the prototype as shown by the elevated levels at the east and west edges. Elevated water contents at these locations are most likely caused by the sloped interface between the silt loam and coarser shoulder ballast, which forms a capillary break. Such a configuration could facilitate the downward movement of water along the interface between the silt loam and side-slope material.

Figure 2.18 and Figure 2.19 compares the spatial distribution of volumetric water content, $\theta$, measured horizontally under the asphalt layer on March 1995 and in May 2008, and in May 2009. After 15 years, the spatial trends in $\theta$ remain quite similar with only small increases in moisture near the edge of the 

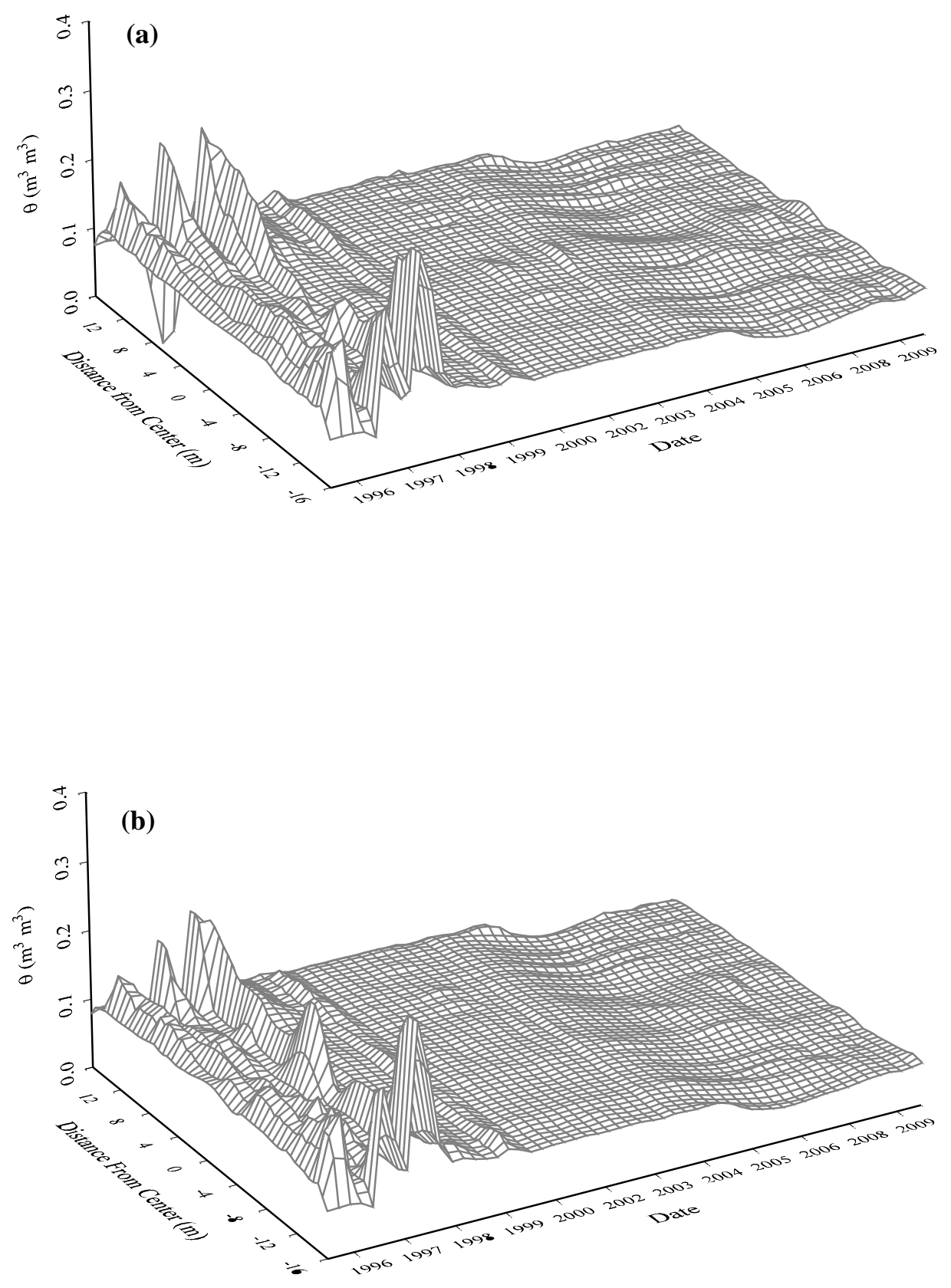

Figure 2.16. Spatiotemporal Variations in Soil-Water Content at the Bottom of the Silt-Loam Layer of the Irrigated Treatment of the Barrier: (a) northern end of treatment, tube AA1 + AA5, and (b) southern end of treatment, tube AA2 + AA6 

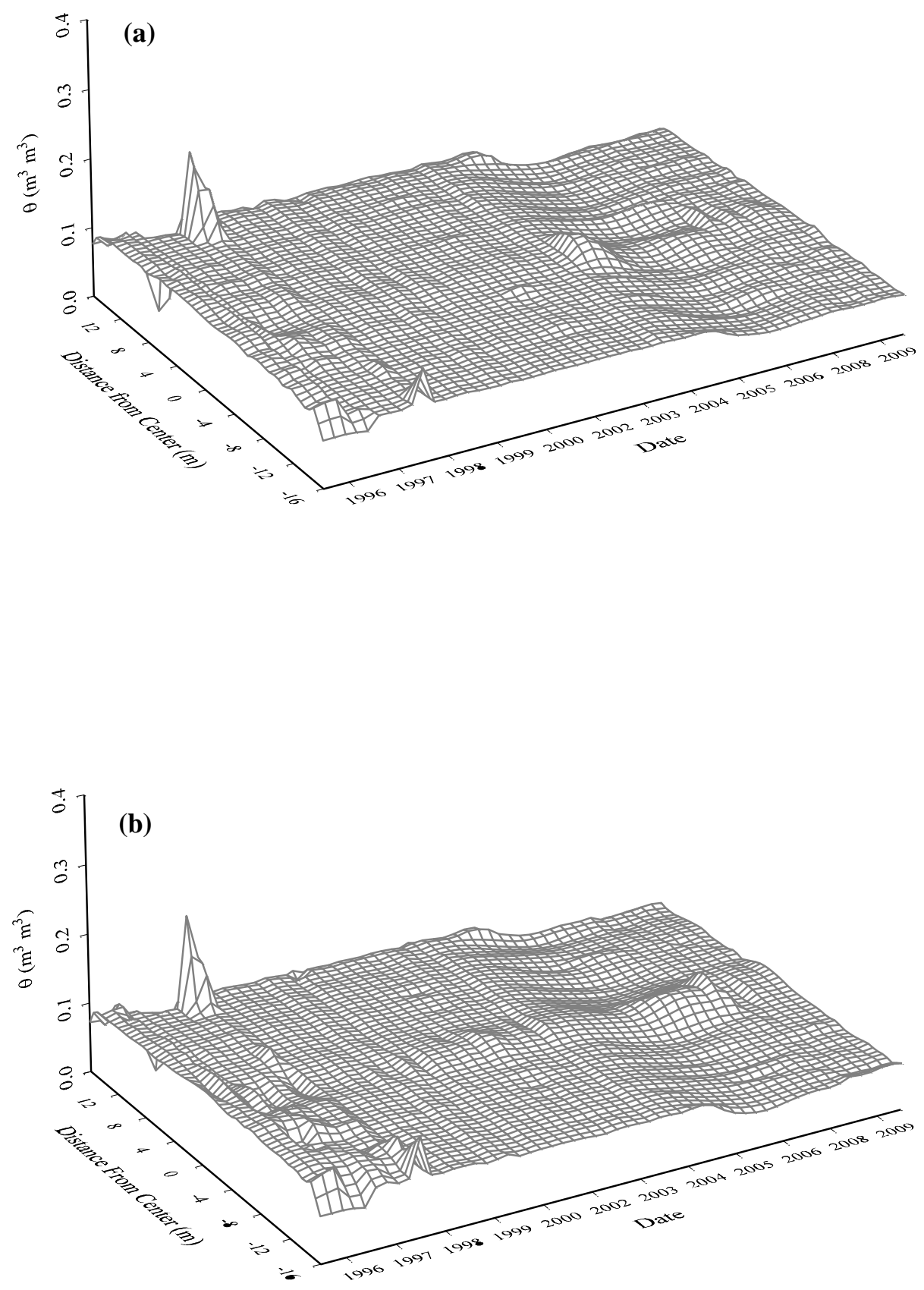

Figure 2.17. Spatiotemporal Variations in Soil-Water Content at the Bottom of the Silt-Loam Layer of the Nonirrigated Treatment of the Barrier: (a) northern end of treatment, tube AA3 + AA7, and (b) southern end of treatment, tube AA4 +AA8 

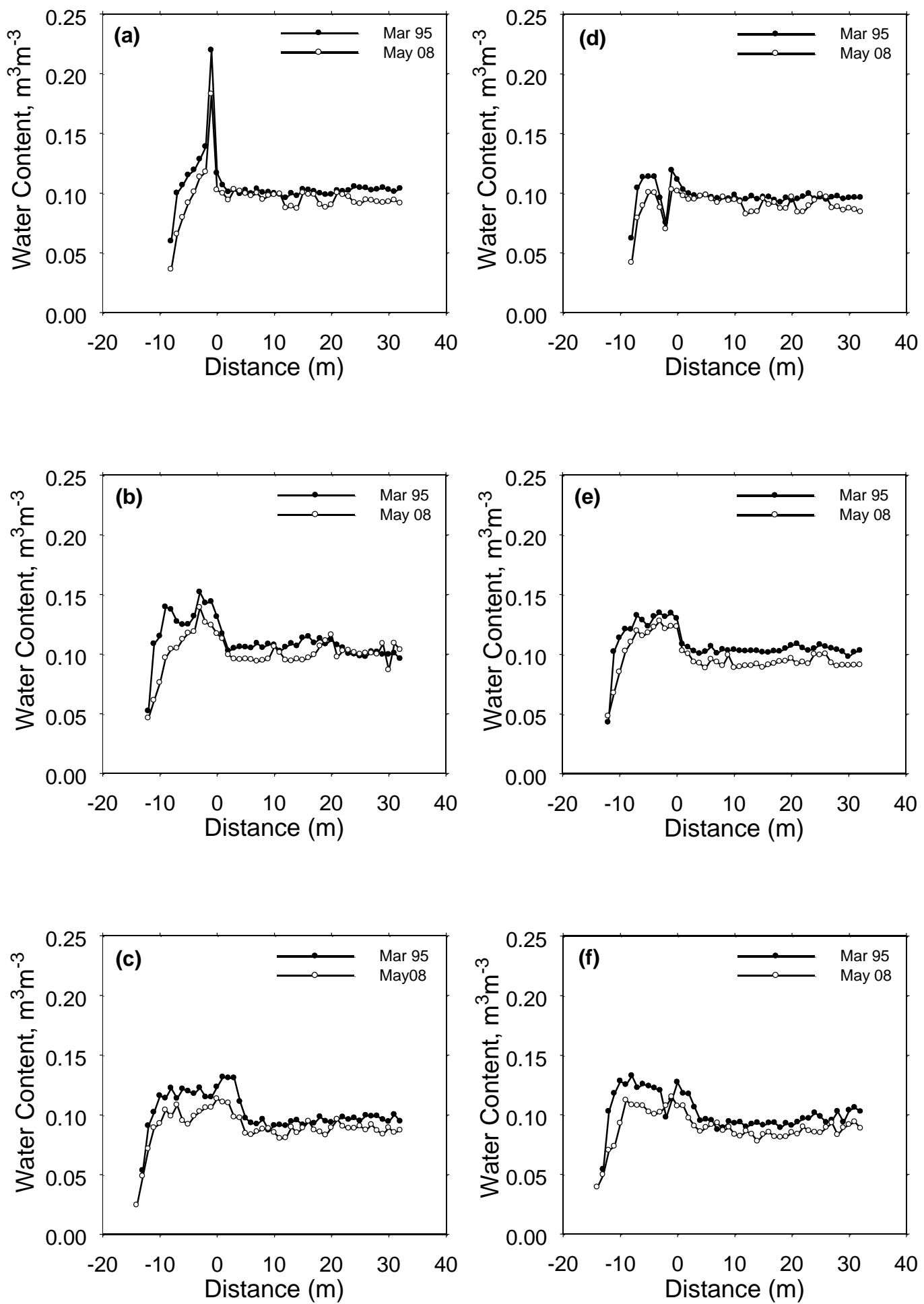

Figure 2.18. Spatial Variation in Soil-Water Content Under the Asphalt Layer (Uncurbed Section) on March 28, 1995, and, May 23, 2008: horizontal neutron tubes (a) BA 1 at 1m, (b) BA 3 at $2 \mathrm{~m}$, (c) BA 5 at $3 \mathrm{~m}$, (d) BA 2 at $1 \mathrm{~m}$, (e) BA 4 at $2 \mathrm{~m}$, and (f) BA 6 at $3 \mathrm{~m}$ 

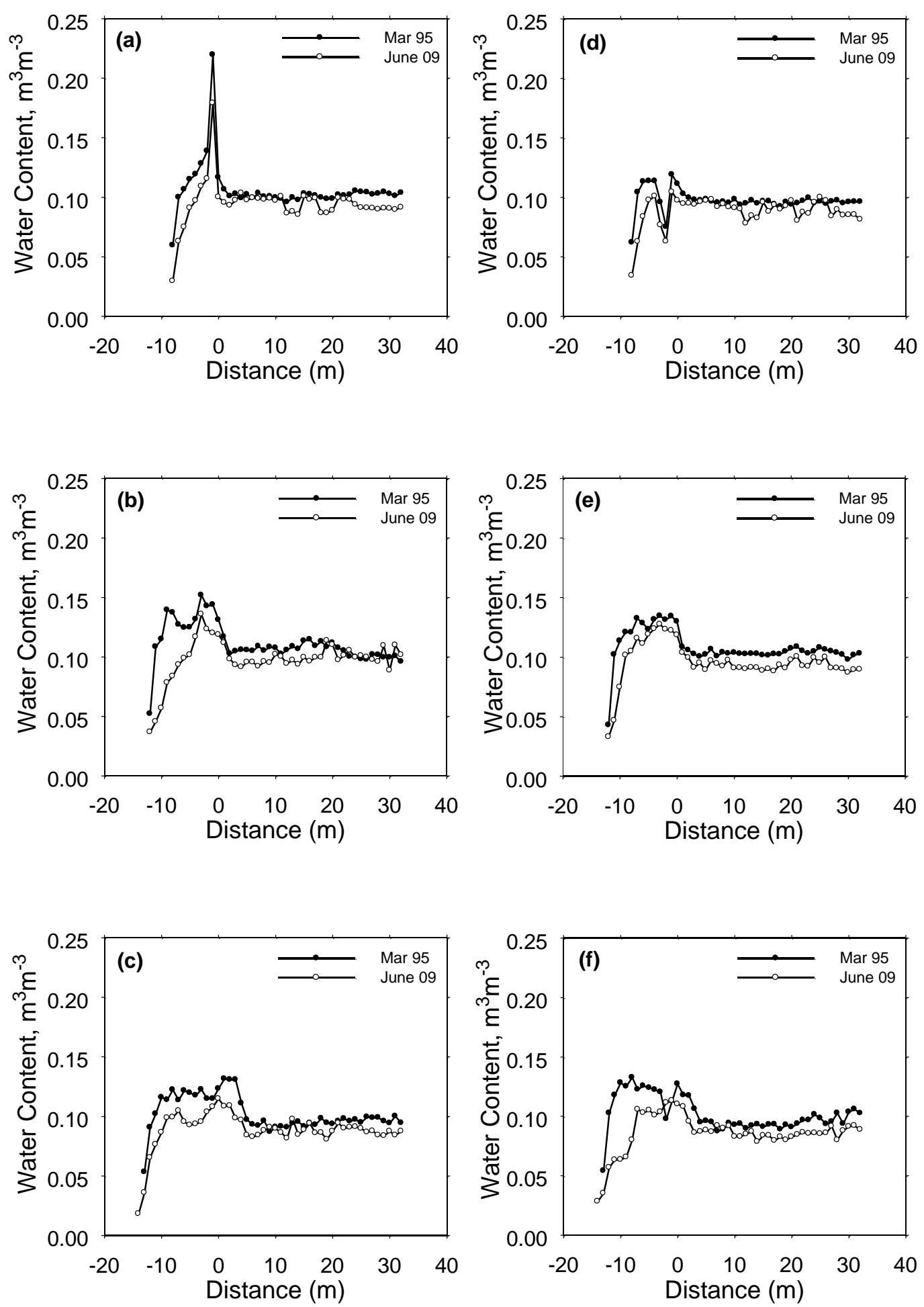

Figure 2.19. Spatial Variation in Soil-Water Content Under the Asphalt Layer (Uncurbed Section) on March 28, 1995, and, June 30, 2009: horizontal neutron tubes (a) BA 1 at 1m, (b) BA 3 at $2 \mathrm{~m}$, (c) BA 5 at $3 \mathrm{~m}$, (d) BA 2 at $1 \mathrm{~m}$, (e) BA 4 at $2 \mathrm{~m}$, and (f) BA 6 at $3 \mathrm{~m}$ 
asphalt layer in the winter. Overall, there has been a decrease in moisture content directly beneath the asphalt layer. Typically, the wetting front migrates about $1 \mathrm{~m}$ under the asphalt before evapotranspiration curtails any further migration. While the extent of the annual migration of the wetting front appears small, underflow remains a major factor for consideration in the design of final covers. Except for a small section near the northeastern corner, the asphalt layer is almost totally curbed to prevent the discharge of water along the edge. These data show that a potential exists for underflow along the edges, although the true extent cannot be determined from the data because of the presence of curbs on the asphalt layer to allow measurement of percolation.

\subsubsection{Evapotranspiration}

Perhaps the three most important factors controlling the hydrologic performance of capillary barriers are soil type, climate, and vegetative cover. The role of the vegetative cover is manifested through the process of evapotranspiration, ET. Apart from plant characteristics, this process in itself is influenced by a number of factors including soil physical characteristics and climatic conditions. An evapotranspirative barrier in concert with a capacitive barrier forms a store-and-release barrier, which is designed to maximize ET, and thereby limit percolation to the underlying waste zone. At the field scale, ET is typically difficult to measure directly. However, it can be estimated from a water balance as the difference between water inputs, storage, and losses as shown in Equation 2.2.

Data collected at the barrier were used to solve the water-balance equation and to calculate ET for each soil-covered plot on the two precipitation treatments at the barrier. The calculated ET rates also were compared with those calculated for previous years. Figure 2.20 shows a plot of ET from 1994 through 2009. During the 3-yr treatability test, calculated ET showed essentially no intra-plot difference but showed significant treatment differences with the highest amounts coming from the north plots. In the first year of monitoring, a mean ET of $744 \mathrm{~mm}$ was calculated for the north plot whereas only $396 \mathrm{~mm}$ was calculated for the south plots. The total ET declined sharply over time reaching a minimum of 156 $\mathrm{mm}$ on the north half and $124 \mathrm{~mm}$ on the south half in 1999. Since then ET has hovered around a mean value of about $167 \pm 40 \mathrm{~mm}$ each year.

Figure 2.21 compares the average ET rate $\left(\mathrm{mm} \mathrm{d}^{-1}\right)$ for each year for the north and south plots from 1994 through 2009. This figure is also based on water balance calculations but uses only data from the beginning and end of the year. Improved temporal resolution in ET can be derived from short-term water balance using the detailed precipitation, storage data and drainage data reported in the earlier sections. The ET rates were initially higher rates on the north section (Figure 2.21a) of the barrier than on the south section (Figure 2.21b). During the treatability test, calculated ET rates were not significantly different between plots on the two precipitation treatments. However, the difference between the north and south (irrigated and unirrigated) sections is quite clear. In the early part of the treatability test through 1998, the average ET rate was almost twice as high on the north as on the south. This can be expected because under wetter conditions, plants will transpire more water, within limits. Over time, all plots showed a general decline in the average rate of ET, with the decline being more pronounced on the northern plots. The decline is due to a combination of factors. First, the reduction observed from 1995 to 1996 may be related partly to the sharp change in the plant population on the barrier. In 1996, there was no Russian thistle (Salsola kali) present, compared to 1995 when this species dominated the vegetative cover of the barrier. The absence of Russian thistle in later years would have helped to reduce ET rates. Second, it is hypothesized that the native shrubs on the irrigated treatment experienced some stress from the excess water, which could have impaired their ability to recycle the water. This hypothesis is supported by 


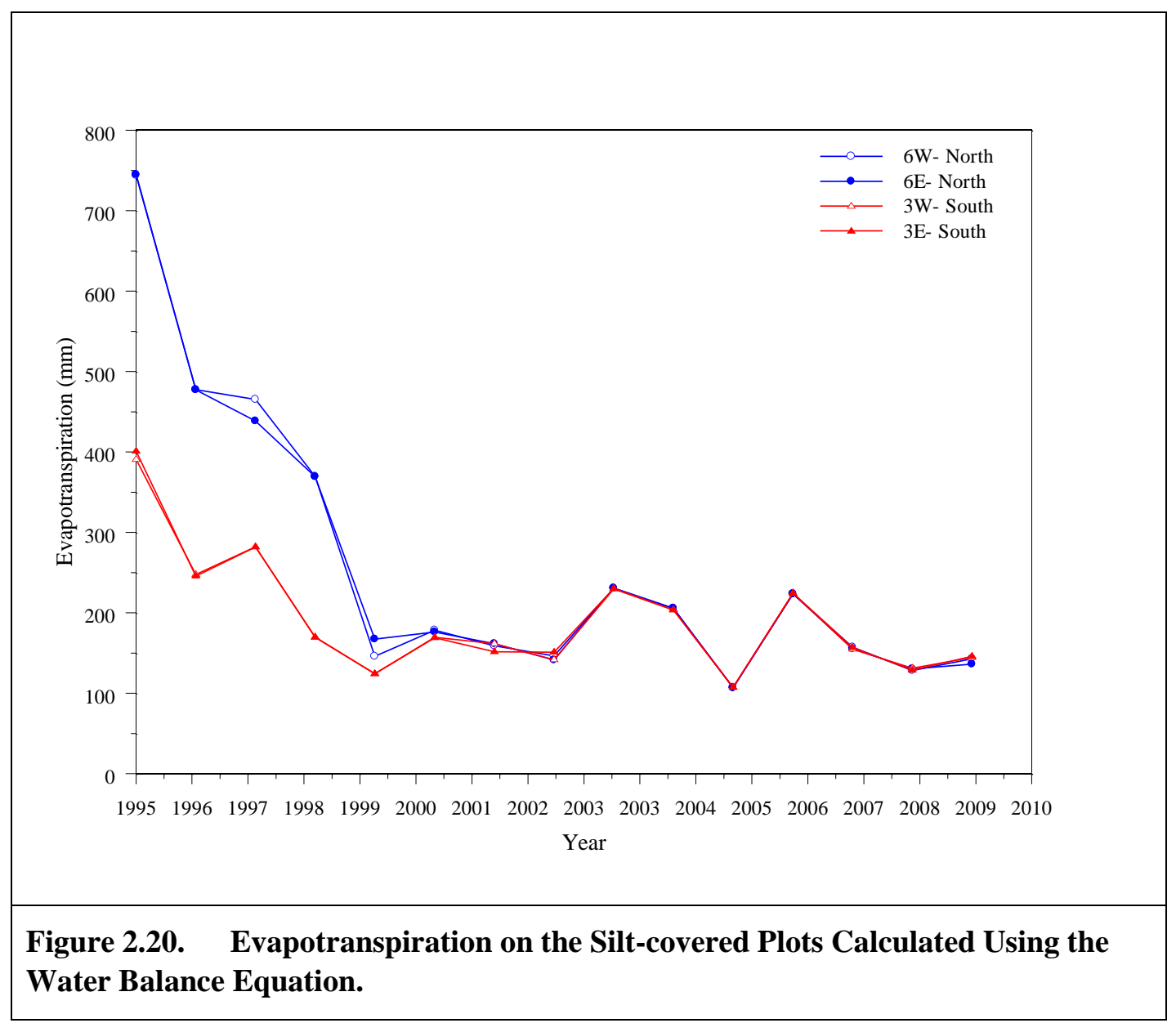



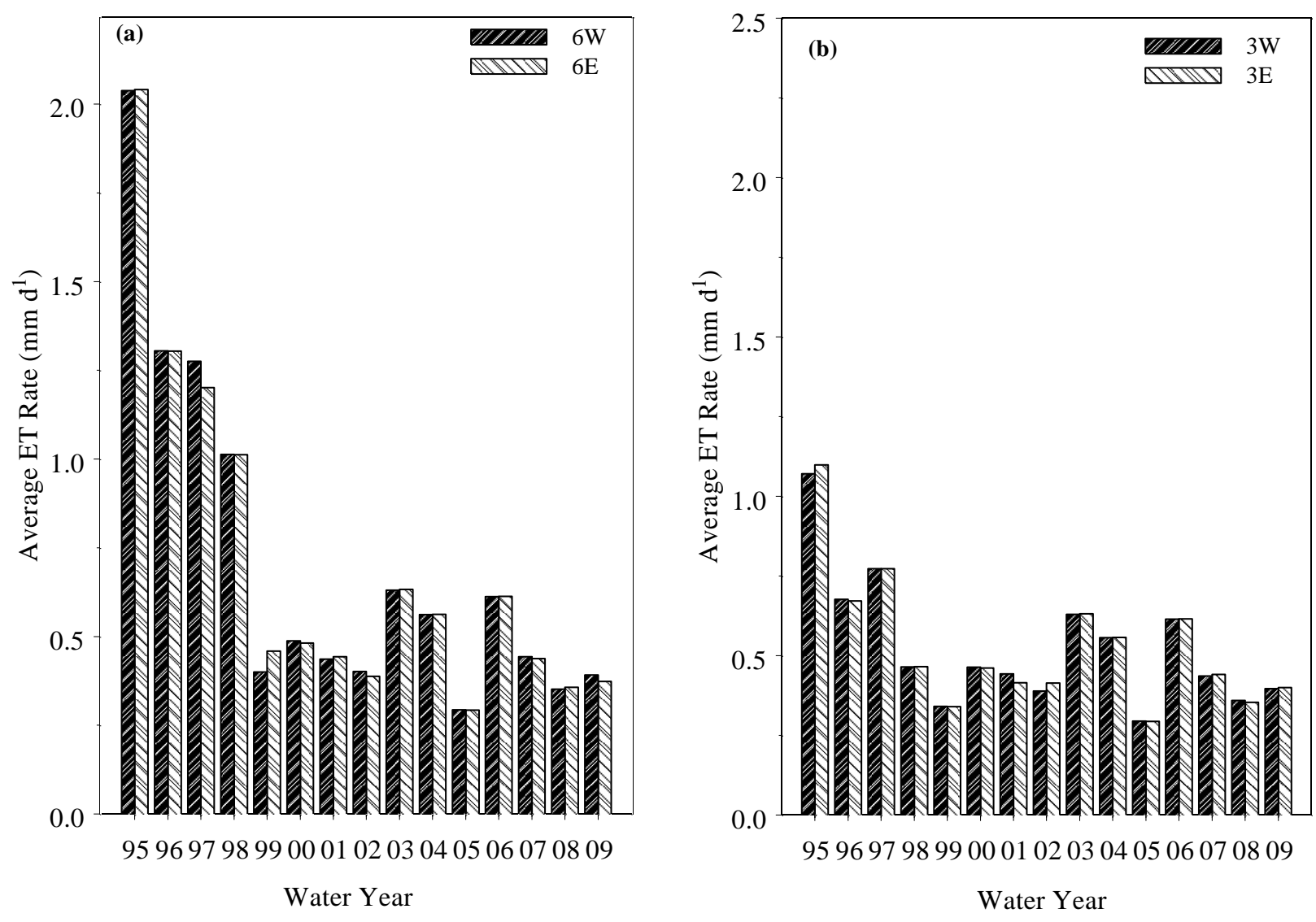

Figure 2.21. Comparison of Average Evapotranspiration Rate at the Prototype Hanford Barrier: (a) North Plots, 6W and 6E, and (b) South Plots, 3W and 3E

observed differences in water storage between the north and south plots at the end of each year. For the duration of the treatability test and for another two years, the lower level of water storage on the north section remained higher than on the south suggesting that the plants were unable to remove all of the water. While the ET rate continued to decline through 1997 on the north plot (Figure 2.20a), the rate increased slightly on the southern plots (Figure 2.20b).

The exception to the general decline is 1997 when the southern plots showed a slight increase, perhaps in response to the wetter than normal conditions that occurred that year. Following the cessation of irrigation at the end of WY 1997, the difference in ET rates on the north and south treatments started to decline. By the end of WY 2000, the difference in average rates was only $0.02 \mathrm{~mm} \mathrm{~d}^{-1}$; by the end of WY 2002, the rates were essentially equal. The convergence of rates suggests that the shrubs on the north section may have finally recovered from the stresses caused by over 3 years of elevated precipitation. All of the plots then showed an increase in ET rate for the first time since WY 1997. These increases are due to the increased availability of water for plant uptake caused by elevated precipitation. Similarities in precipitation amounts and distribution in 2008 and 2009 resulted in almost identical rates. 
Given that the final values of water storage were similar on the north and south plots (Section 2.2.2), and no drainage has been observed, the difference in ET rate can be attributed solely to increased water losses from the upper layers. The ET rates in 2008 and 2009 were essentially the same. However, since 1995, ET rates on the north side have declined by over $81 \%$ whereas rates have declined by only $63 \%$ on the south plots. This is consistent with a general decline in precipitation over the same period. On the north side, the average ET rate decreased from $2.09 \mathrm{~mm} \mathrm{~d}^{-1}$ in 1995 to $0.382 \mathrm{~mm} \mathrm{~d}^{-1}$ in 2009 . On the south side, the average ET rate decreased from $1.08 \mathrm{~mm} \mathrm{~d}^{-1}$ in 1995 to $0.398 \mathrm{~mm} \mathrm{~d}^{-1}$ in 2009 . The mean ET rate on the north in 2009 was a $7.4 \%$ increase from the $0.354 \mathrm{~mm} \mathrm{~d}^{-1}$ calculated for 2008 . On the south side, the mean rate increased by $10.5 \%$ from $0.356 \mathrm{~mm} \mathrm{~d}^{-1}$ calculated in 2008 . These data also show that the native plants can easily adapt to short-term changes in precipitation, adjusting their ET rates to match changes in precipitation and increases in available soil water. Data from the prototype barrier show that the native plant species are capable of routinely recycling precipitation in excess of the long-term average value for the Hanford Site. Although the plants can easily recycle precipitation of about twice the longtime average value for the site, their ability to efficiently recycle precipitation at more than three times the long-term annual average value may be limited to periods of 3 years or less. The simplified water balance equation used in this analysis cannot separate evaporation from transpiration. However, the smaller change observed on the north side over the last year is consistent with the reduced rate of water loss and higher remaining water storage at the end of the year inferred from the water storage calculations for the burned and unburned sections.

\subsection{Summary}

Performance monitoring of the prototype Hanford barrier continued through FY 2009 with a scope similar to that following the completion of the treatability test. Differences in water storage between the northern and southern sections of the barrier have essentially disappeared. Inter plot and intra plot divergence of the lower limits of water storage also have essentially disappeared, although there are still small differences between the northeast corner and the rest of the barrier. Earlier differences may have been due to irrigation-induced stress but data collected since the completion of the treatability test suggest that the effect of stress may have been temporary. Persistent differences may be due to differences in plant species composition on the northeastern plot. The data reported here support the premise that barrier designs based on the concept of the store and release should work well at Hanford and handle short-term variations in precipitation and perturbations to the plant community that might impact changes in waterrecycling efficiency. Data collected during the last year to document the effects of wild fire on performance show that even in the absence of plants water storage is limited by evaporative processes. After receiving the same amount of precipitation the burned north side of the barrier showed nearly the same storage as the unburned south side at the end of September 2009, one year after the fire. Of course, the degree of performance will depend on using appropriate design variables such as soil type, thickness, and plant species composition.

Since the treatability test, precipitation has been around average, and increases in storage have been mostly less than $50 \mathrm{~mm}$ on both sides of the barrier. Total precipitation in FY 2009 was similar to that in 2008 and was slightly less than normal (172 mm). During 2008 and early 2009, there were no significant differences in water storage between the north and south. However, removal of vegetation from the north side at the end of 2008 resulted in significant differences in total water storage as well as the rate of accumulation and loss of water.

Drainage monitoring continued as in previous years, and similar trends have been observed. Results show a complicated relationship between side-slope configuration and precipitation depending on 
irrigation treatment during the treatability test. On the plots that were irrigated, there is now very little difference between the cumulative drainage from the gravel and riprap side slopes for the duration of monitoring. However, data collected after the end of the treatability test show that the gravel slope exceeds the riprap in drainage. On the non-irrigated side of the barrier, cumulative drainage from the gravel slope exceeds that from the riprap for the entire monitoring period. However, for the period after the treatability test, drainage from the gravel and riprap slopes are essentially equal. The soil plots have produced essentially no drainage. The rock slope continues to show a smaller amount of drainage which has been attributed to advective drying.

Horizontal neutron-probe measurements above and below the asphalt shows no evidence of deep percolation of water. Lateral movement of water under the asphalt layer was quite limited. Waterbalance calculations show an increase in evapotranspiration relative to the period immediately after the treatability test because of increases in precipitation and available soil water as well as plant biomass. Annual ET has declined from over $700 \mathrm{~mm}$ on the north plots and $396 \mathrm{~mm}$ on the south plot in 1995 to around $140 \mathrm{~mm}$ on both plots in 2009. ET rates on the north plots have declined from a high of $2 \mathrm{~mm} \mathrm{~d}^{-1}$ n 1995 to $0.38 \mathrm{~mm} \mathrm{~d}^{-1}$ in 2009. On the south plots, ET rates declined from a high of $1.08 \mathrm{~mm} \mathrm{~d}^{-1}$ in 1995 to $0.40 \mathrm{~mm} \mathrm{~d}^{-1}$ in 2009 . Rates in 2009 increased by $10.5 \%$ on the unburned side but by only $7 \%$ on the burned side. Water loss from the burned side was primarily be evaporation. 


\subsection{Barrier Stability}

The objective of this task was to monitor the stability of the barrier by measuring elevation changes in the subgrade below the asphalt layer and the surface soil layer and by measuring displacements in the riprap side slope. The scope of the effort involved taking elevation surveys at the surface 3-m by 3-m grid stakes (338 stakes total) and two settlement markers as well as displacement (vertical and horizontal) surveys of the 15 creep gauges. Survey data are provided in Tables A.3 through A.5. Stability surveys were conducted in December 1994, July 1995, September 1995, January 1996, September 1996, January 1997, September 1997, July 1999, August 2000, August 2001, August 2002, August 2003 (DOERL 1999; Fluor Hanford 2003) ${ }^{(\mathrm{a}, \mathrm{b}, \mathrm{c})}$,May 2004 (Ward et al 2005), September 2007, September 2008, and July 2009.

\subsection{Methodology}

The surface of the barrier was demarcated with a coordinate system established by a 3-m by 3-m grid as shown in Figure 2.1. Each interior grid point is marked with a metal survey stake, replacing the previous wood stakes, numbered to identify the grid coordinate. Elevation measurements were taken at the location of each stake on the 3-m by 3-m grid using an electronic distance measurement (EDM) system. To enable monitoring of the order and magnitude of settlement in the subgrade below the asphalt layer (i.e., beneath the barrier) and within the barrier, two settlement markers have been installed. One marker is located at the northern end of the barrier (DSG1), near the crown, and the other marker is located about $14 \mathrm{~m}$ to the east of the first marker (DSG2). Movement of the asphalt surface is an indicator of subgrade settlement and is quantified by measuring the change in the elevation of the top of the settlement marker rods.

To enable monitoring of the riprap side-slope stability, creep gauges were installed at 13 locations (CG1 through CG13b) in the eastern slope (Figure 2.1). At 11 of the 13 locations, a gauge is located at the mid-slope position on the riprap. At the other two locations, two gauges are installed (CG10a and CG10b; CG13a and CG13b), at the upper and a lower slope position, respectively. Additional descriptions of the monitoring stations can be found in DOE-RL (1999). Since installation, the additional creep gauges have been surveyed roughly on a quarterly basis except for the last year in which there was a single survey. Previous quarterly surveys have been performed at least annually and sometimes as frequently as quarterly. From the start of monitoring, elevation measurements were made by EDM using a laser theodolite system. Surface elevations were made on the 3-m by 3-m grid, including the settlement gauges at least once per year. In FY 2004, for the first time, the EDM

(a) CCN 073428, 1999, “200-BP-1 Prototype Hanford Barrier Annual Monitoring Report for FY 1999," (letter to B. L. Foley, U.S. Department of Energy, Richland Operations Office), from M. J. Graham, Bechtel Hanford, Inc., Richland, Washington, September 30.

(b) CCN 083132, 2000, "200-BP-1 Prototype Hanford Barrier Annual Monitoring Report for Fiscal Year 2000," (letter to B. L. Foley, U.S. Department of Energy, Richland Operations Office), from M. J. Graham, Bechtel Hanford, Inc., Richland, Washington, October 19.

(c) CCN 100381, 2002, "200-BP-1 Prototype Hanford Barrier Annual Monitoring Report for FY 2001," (letter to B. L. Foley, U.S. Department of Energy, Richland Operations Office), from M. J. Graham, Bechtel Hanford, Inc., Richland, Washington, June 18. 
technique was replaced due to an equipment malfunction. The EDM system has fallen out of calibration and cannot be serviced.

For the first time in FY 2004, two technologies were evaluated for extracting high-resolution topographic data for the prototype barrier. The EDM survey was replaced with a real-time-kinematic (RTK) global positioning system survey and digital photogrammetry using aerial photographs of the barrier. A complete survey of the prototype barrier was performed using GPS. The GPS surveying equipment consisted of a Trimble RTK 5700 base station with a RTK 5800 rover and a Trimmark 3 Base Station Radio with a 6-ft whip antenna, all manufactured by Trimble Navigation Limited (Sunnyvale, CA). For the survey, the base station was placed over a known point, this being benchmark 2E-122. Using its known position, the base station continually determines what the signal travel times from the GPS satellites to the base station should be and then compares this to the actual travel time. Using this information, the base station then calculates a satellite-specific correction factor, which it then broadcasts to the rover unit using the base-station radio. The rover unit uses the correction factors for dynamic corrections of the rover's GPS measurements. This process allows the accuracy of the GPS system to be improved from meters to less than a centimeter.

At each survey point, a 10-second reading was taken with the rover unit at the top of the wooden stake and on the ground surface adjacent to the stake using a solid plastic holder to prevent penetration of the whip antenna from penetrating the soil surface. From investigations of the optimum measurement times, it was determined that a 10 -second reading provided the most accuracy with no appreciable accuracy gain after 10 seconds. All data points were stored in the rover unit and later downloaded to a PC. Data were processed using Trimble Geomatics post-analysis software and used to generate the DEM. In the past, surveying the entire barrier, including the surface, creep gauges, and settlement gauges took about 4 hours. The RTK elevation survey was performed in August 2008 and July 2009. The results are summarized in Table 3.1.

\subsection{Results}

\subsubsection{Settlement Gauges}

Table 3.1 summarizes the settlement gauge elevation and changes since December 1994 when the first survey was completed. Since the last survey recorded in the treatability test report, the two settlement gauges (Figure 2.1) have shown very slight changes in elevation. These changes were typically within the range of measurement error of the EDM. The only divergence from this trend occurred in FY 2004 when measurement methods were changed and the result was $0.078 \mathrm{~m}$ increase in elevation. This change was later attributed to error and in fact subsequent measurements have fallen back into the range observed in previous years. In FY 2008, the two gauges showed a mean increase of $0.0025 \pm 0.0007 \mathrm{~m}$ from the reading in 1994. In FY 2009, elevation decreased from the FY 2008 reading and decreased by $0.0005 \pm$ $0.0007 \mathrm{~m}$ from the 1994 reading. These changes are obviously very small and are indicative of a stable barrier system.

\subsubsection{Creep Gauge Movement}

Figure 3.1 and Figure 3.2 show temporal plots of gauge location for the duration of monitoring. The polar plots are used to quantify the magnitude and direction of the horizontal component to the displacement vector. However, the plots provide no information about vertical changes. Figure 3.1 shows 
Table 3.1. Elevations and Elevation Changes of Settlement Gauges from December 1994 for Through July 2009

\begin{tabular}{|l|c|c|c|c||}
\hline \multicolumn{1}{|c|}{ Date } & DSG1 (W) & $\begin{array}{c}\text { Elevation } \\
\text { Change (m) }\end{array}$ & DSG2 (E) & $\begin{array}{c}\text { Elevation } \\
\text { Change (m) }\end{array}$ \\
\hline Dec 1994 & 201.954 & 0.000 & 201.687 & 0.000 \\
\hline Sep 1995 & 201.958 & 0.004 & 201.690 & 0.003 \\
\hline Jan 1996 & 201.967 & 0.013 & 201.698 & 0.011 \\
\hline Sep 1996 & 201.965 & 0.011 & 201.698 & 0.011 \\
\hline Jan 1997 & 201.961 & 0.007 & 201.686 & -0.001 \\
\hline Sep 1997 & 201.963 & 0.009 & 201.698 & 0.011 \\
\hline Jul 1999 & 201.950 & -0.004 & 201.683 & -0.004 \\
\hline Aug 2000 & 201.951 & -0.003 & 201.658 & -0.029 \\
\hline Aug 2001 & 201.947 & -0.007 & 201.675 & -0.012 \\
\hline Aug 2002 & 201.948 & -0.006 & 201.683 & -0.004 \\
\hline Aug 2003 & 201.953 & -0.001 & 201.687 & 0.000 \\
\hline May 2004 & 202.032 & 0.078 & 201.763 & 0.076 \\
\hline Sep 2007 & 201.956 & 0.002 & 201.682 & -0.005 \\
\hline Sep 2008 & 201.957 & 0.003 & 201.689 & 0.002 \\
\hline Jul 2009 & 201.954 & 0.000 & 201.687 & -0.001 \\
\hline \hline
\end{tabular}


the net horizontal displacement and direction between the last survey (September 2008) and the most recent (July 2009) for all the gauges. Figure 3.2 shows the net horizontal displacement and direction between the first survey (December 1994) and the most recent (July 2009) for all the gauges. Apart from CG-12 and CG-13a, differences between FY 2008 and FY 2009 are consistent with previous results. These data show gauge movement to be mostly in an easterly direction with horizontal displacement ranging from 0.016 to $0.063 \mathrm{~m}$. This range is consistent with that observed in FY 2008 (0.002 to $0.06 \mathrm{~m}$ ) and is not indicative of slope failure. Routine physical inspection over the years has shown no evidence of slope movement.

Changes in elevation of the 15 creep gauges over the last 15 years appear to be quite random, falling within the measurement error of the surveying systems. A relatively large increase of about $0.07 \mathrm{~m}$ in 2007 from the 1995 was attributed to a change in surveying systems (Ward et al. 2007). Subsequent measurements show a reversal with elevation changes more consistent to those observed in the years prior to FY 2004. Relative to the initial positions, elevations changes are quite small and range -0.06 to $0.01 \mathrm{~m}$ for all gauges. The mean change in FY 2009 calculated using all the gauges was $-0.012 \pm 0.019 \mathrm{~m}$.

\subsubsection{Surface Elevation}

Changes in elevation could indicate problems of stability therefore surface elevation measurements have been made at least once per year since the start of monitoring to document barrier stability. Figure 3.3c shows a contour map of surface elevation measured with the Trimble 5800 Real-time Kinematic GPS on July 29, 2009. This is compared to measurements made in December 1994 (Figure 3.3a) and September 2008. These plots show a relatively uniform change in elevation from the middle of the barrier towards the edges to the west and east consistent with the as-built 2-percent slope. The shape of the surface is better visualized in a three-dimensional surface plot as shown Figure 3.4. In general, the surface has not undergone any significant changes in elevation over the last 15 years.

In order to quantify any changes in elevation during the monitored period, elevations from December 1994 were subtracted from those recorded in July 2009. Figure 3.5 shows a plot of the differences between 1994 and 2009. A positive number is indicative of an increase in elevation relative to 1994 whereas a negative number is indicative of a decrease. Current elevations do not show any large difference from 1994 elevations. Relative to December 1994, the surface shows only small increases and decreases (hachured shade) in elevation. Elevation changes ranged from $-0.15 \mathrm{~m}$ to $0.08 \mathrm{~m}$, but there is no consistent trend or spatial pattern. Over the 15 -yr period, the largest increase in elevation was about 8 $\mathrm{cm}$ and occurred in the northwest corner (top left corner of Figure 3.5). The cause for this increase has never been established. The largest decrease in elevation, about $12 \mathrm{~cm}$, occurred in the southeast corner. Owing to its proximity to the steep rip rap slope, additional creep gauges were installed in FY 2000 to allow closer monitoring of this area. Although no further changes have occurred, cause for the initial decrease has never been established. In addition to these two changes, several other small changes can be seen on the surface and can be attributed to both manmade excavations related to instrumentation (e.g. relocation of the runoff plot, bury cables, instrument repair) and small mammal activities such as burrowing and the formation of mounds. Small animal activities and how they may influence elevation changes are discussed in Section 5. There are also some areas where shrubs have died and collapsed leaving small depressions. Some of the earlier increases may have also been caused by increases in plant biomass in the near surface. 


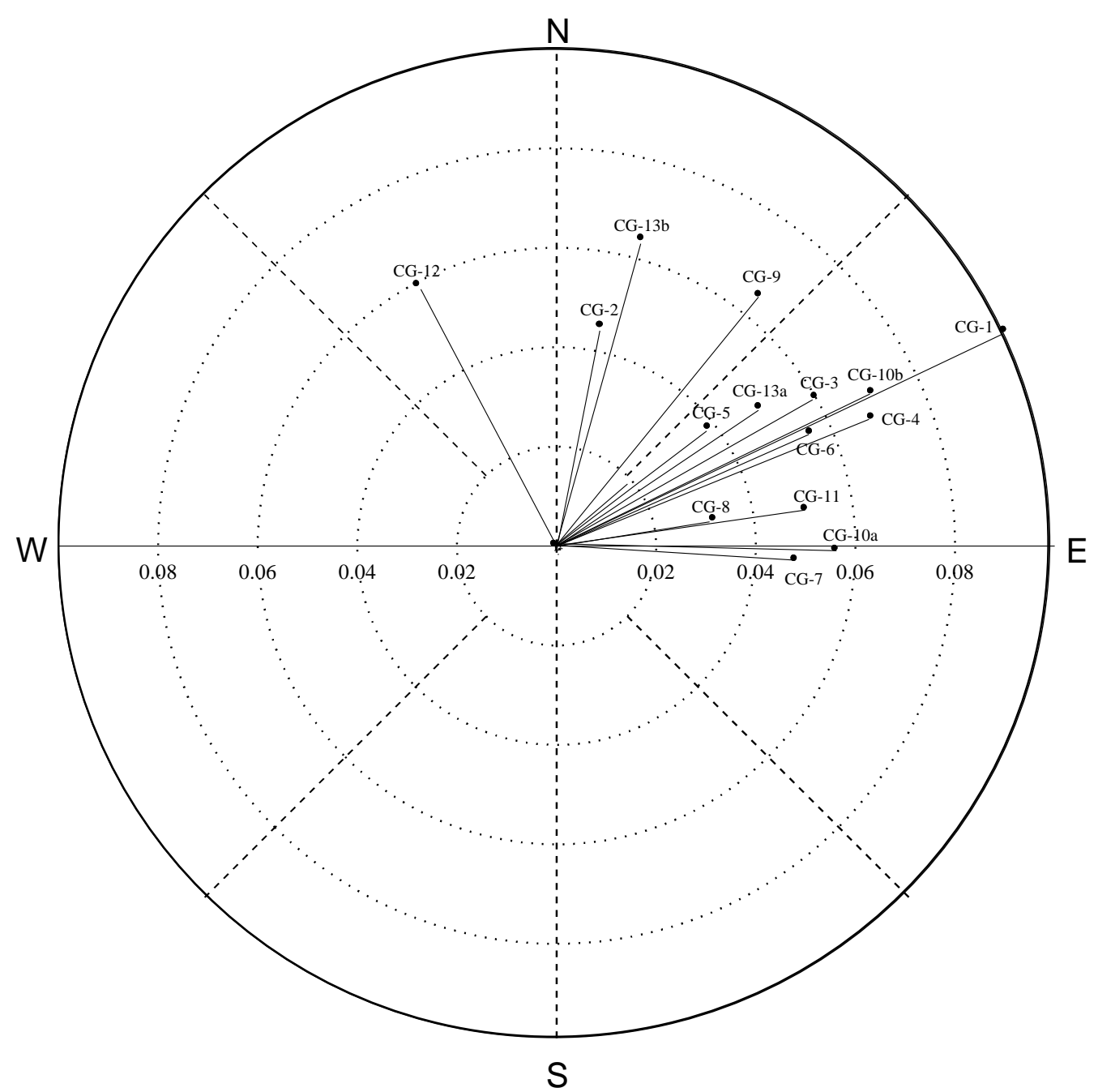

Figure 3.1. Net Creep Gauge Movement Between September 2008 and July 2009. (Elevation measured by EDM until FY 2003, subsequent measurements by GPS; the resultant [horizontal component] is in meters). 


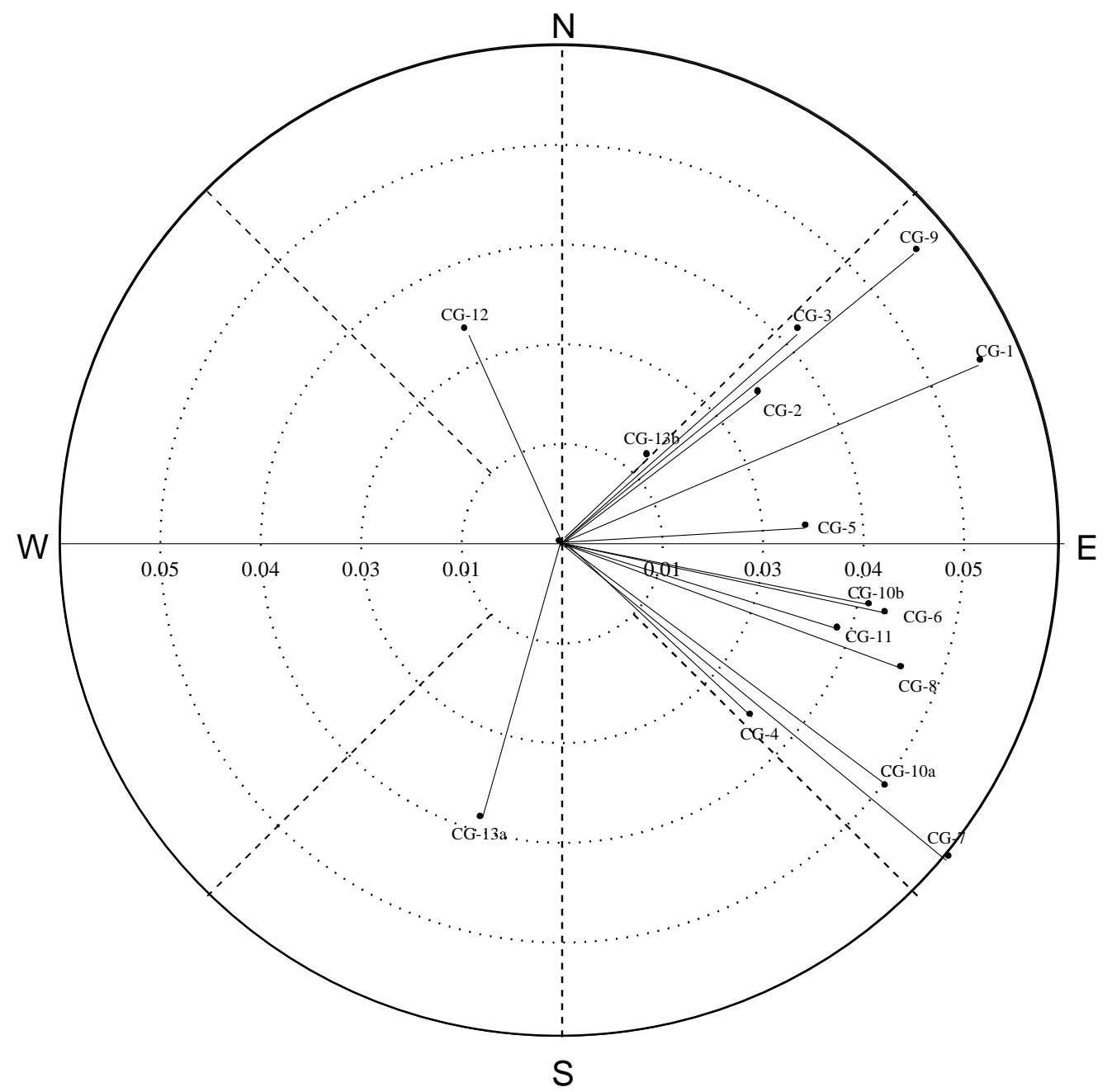

Figure 3.2. Net Creep Gauge Movement Between May December 1994 and July 2009. (Elevation measured by EDM until FY 2003, subsequent measurements by GPS; the resultant [horizontal component] is in meters). 
(a)

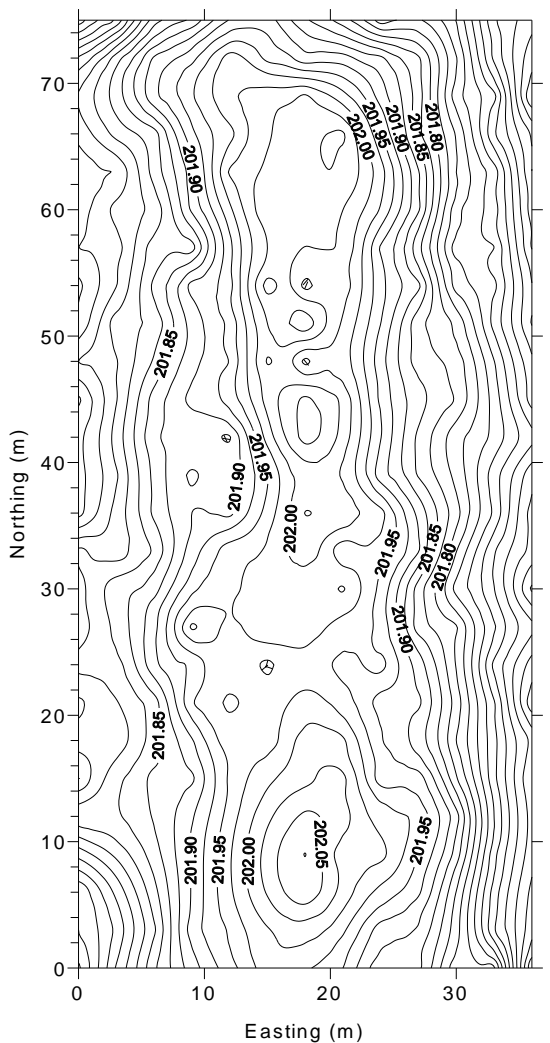

(b)

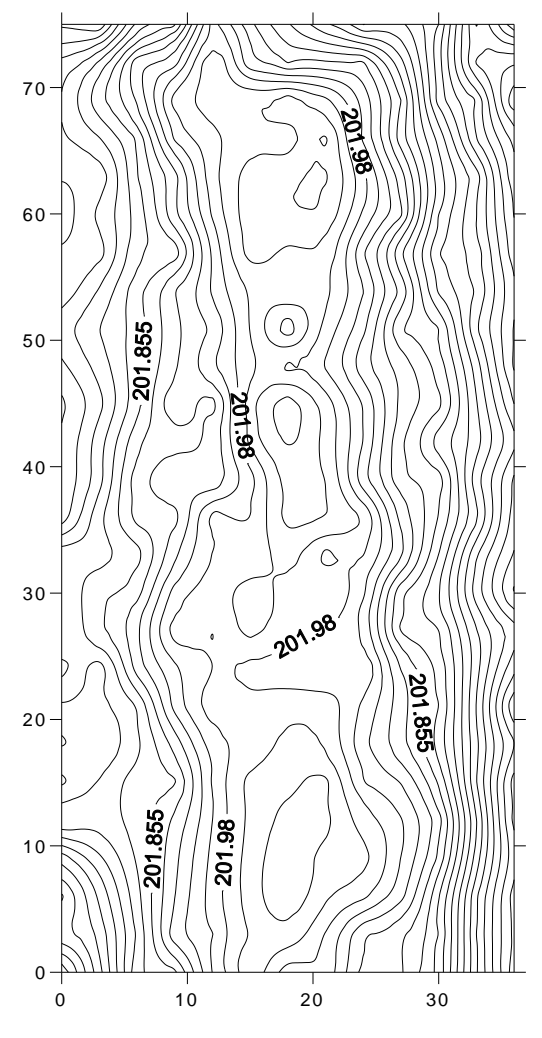

(c)

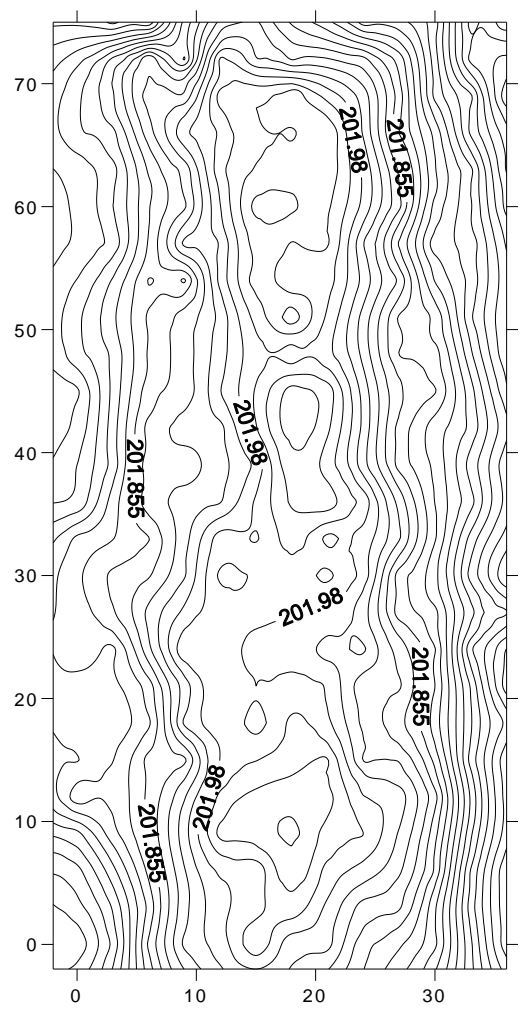

Figure 3.3. Surface Elevation (meters) as the Prototype Hanford Barrier at Three Different Times, (a) December 1994 (b) September 4, 2008, and (c) July 29, 2009. FY 1994 measurements were made using an Electronic Distance Measurement unit whereas FY 2008 and FY 2009 measurements were made using a Trimble real-time kinematic GPS. The contour interval is $0.025 \mathrm{~m}$. 

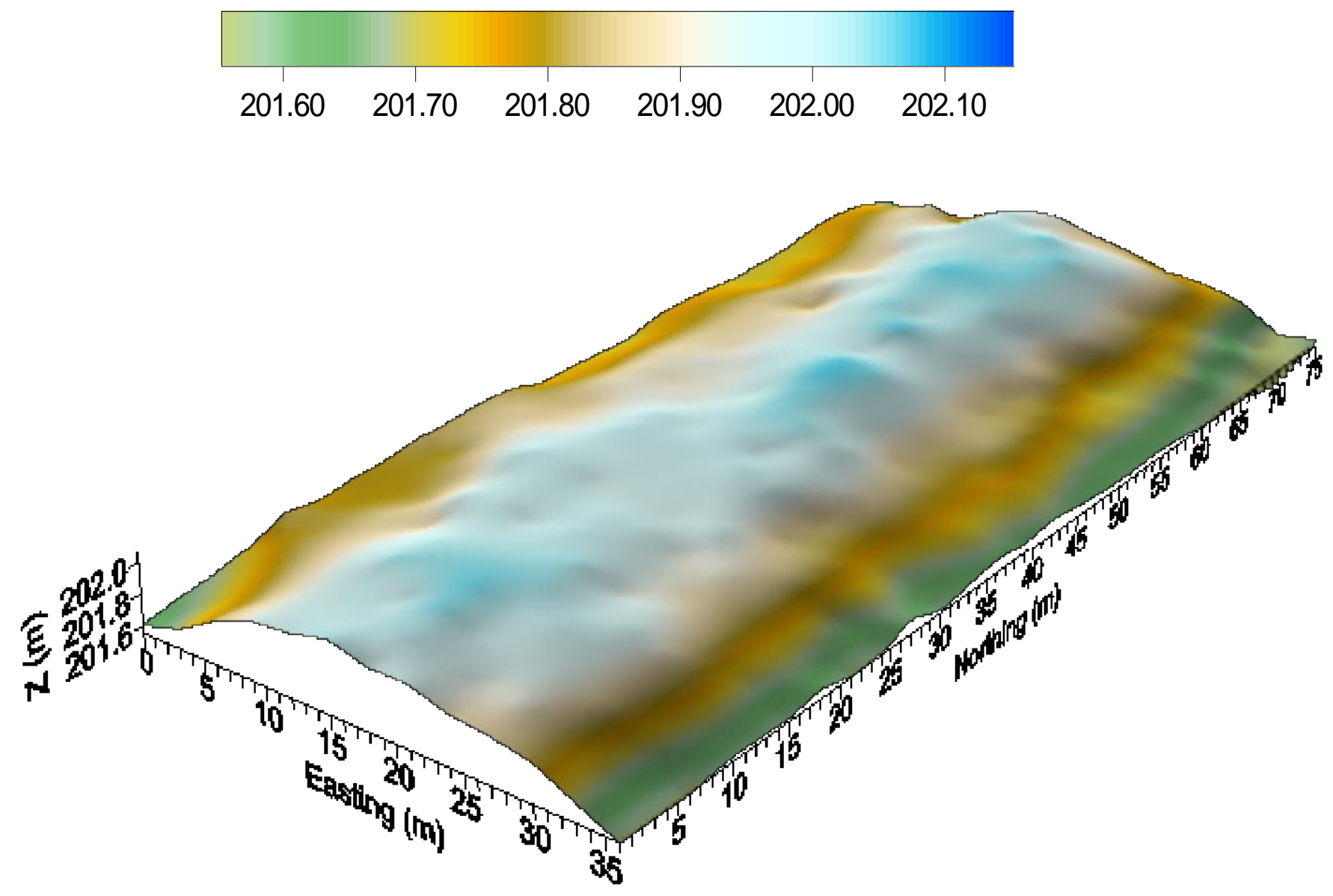

Figure 3.4. Surface Elevation (10× Vertical Exaggeration) at the Prototype Hanford Barrier as of July 29, 2009 Measured Using a Real-Time Kinematic Global Position System. 


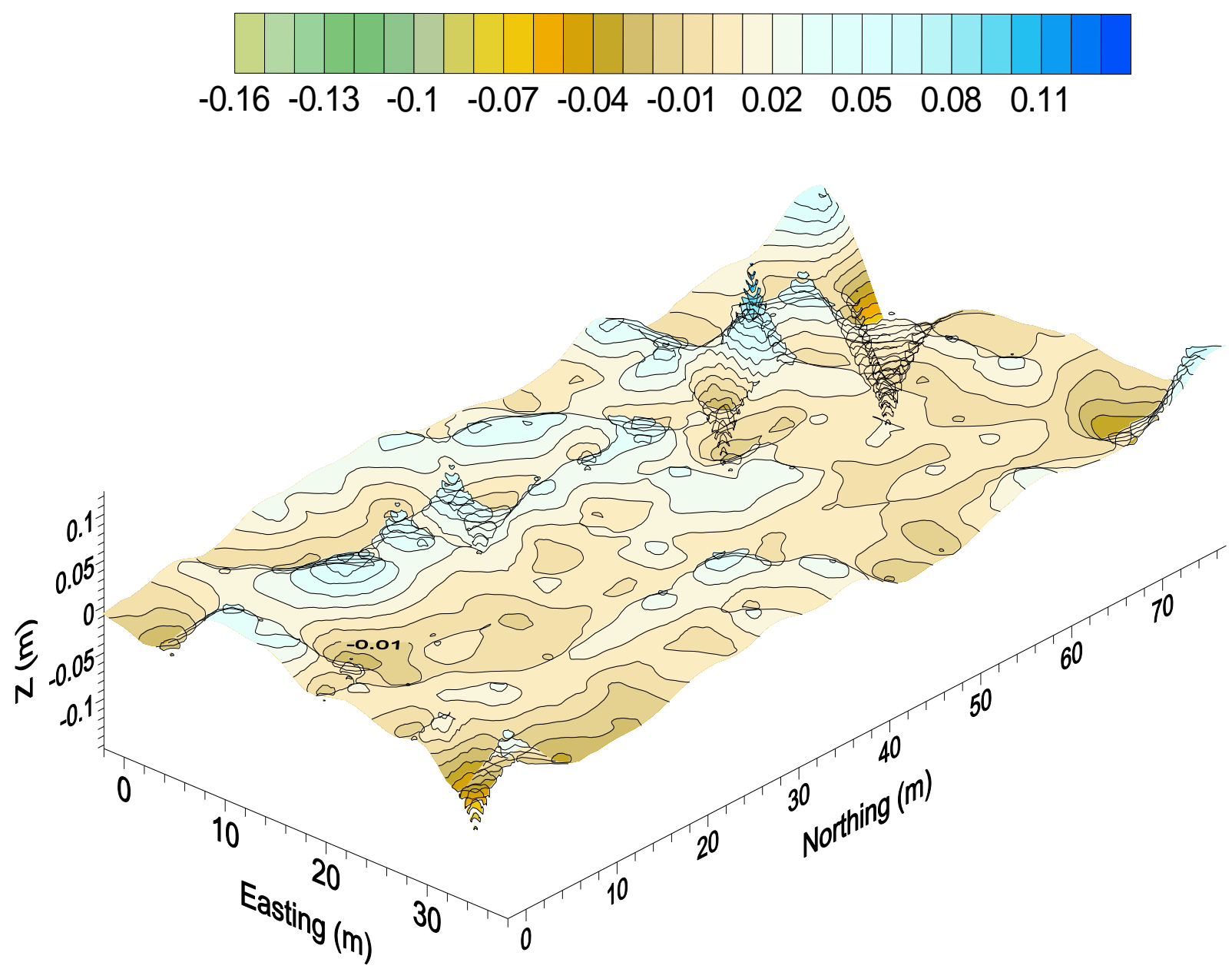

Figure 3.5. Change in Surface Elevation $(66 \times$ Vertical Exaggeration) at the Prototype Hanford Barrier as of July 29, 2009 Measured Using a Real-Time Kinematic Global Position System. 


\subsection{Summary}

Stability of the barrier has been documented over the last 15 years by monitoring (i) surface elevation on the $3 \mathrm{~m} \times 3 \mathrm{~m}$ grid, (ii) the elevation of two settlement gauges anchored to the asphalt layer, and (ii) 12 creep gauges installed on the riprap slope. The original surveys were conventional EDM surveys but more recently data have been collected using aerial photogrammetry and a global-positioning system. The movement in the settlement gauges showed no trend through FY 2009. The FY 2004 survey showed a large increase in elevation over that observed in FY 2003, but this is attributed to the change in survey methods and can be treated as an outlier. In FY 2000, three new creep gauges were installed to the original 13 to allow closer monitoring of the southeastern corner of the riprap side slope. All the gauges have been surveyed at least once per year and as frequently as quarterly. Results show not consistent trend. The most recent results for FY 2009 show gauge movement to be mostly in an easterly direction with horizontal displacement ranging from 0.016 to $0.063 \mathrm{~m}$. Changes in the vertical displacement of the 16 creep gauges over time showed no obvious trends through July 2009 and appear to within the measurement error of the surveying systems. 


\subsection{Ecological Characterization and Monitoring}

This section covers summarizes activities related to the routine monitoring of the structure and dynamics of the plant community and associated ecological processes at the barrier. Measurements were performed over the last year to assess plant species abundance, ground cover, and xylem pressure potential. This information is useful for understanding the role of ecological processes in function of vegetated capacitive barriers.

\subsection{Objectives}

The objective was to collect information on plant characteristics on the north (formerly irrigated) section, south (formerly non-irrigated) section, and the north and west side-slopes. The scope of this study included the documentation of species diversity and measurement of shrub height, greatest canopy diameter, and the diameter at the center of the plant perpendicular to the greatest diameter were measured on 25 shrubs each from sections of the barrier. Cover of grass, shrubs, forbs, litter, soil, and soil cryptogams was determined on the surface and on the side slopes. With this year being one year after the controlled burn test on the north side of the barrier, general assessments of shrub survival, re-sprouting, and recruitment were also made.

Surveys of vegetation on the Prototype Hanford Barrier and side slopes were conducted between August 3 and September 13, 2009. Species were identified in the field or in the laboratory with collected specimens with naming according to the USDA NRCS (2009).

\subsection{Methodology}

Surveys of vegetation on the Prototype Hanford Barrier and side slopes were conducted in August 2009. Plant species were identified for the formerly irrigated, now burned, and non-irrigated (unburned) halves of the surface and also on the north and west side slopes. Soil cryptogams were identified (Link et al. 2000) on the formerly irrigated and unburned halves of the surface.

Cover of grass, shrubs, forbs, litter, soil, and soil cryptogams was determined on the surface and on the side slopes. Cover classes were estimated after Daubenmire (1959). Soil and soil cryptogam cover estimates were combined for an estimate of bare ground cover for comparison with previous years. This was done in each of 300 quadrats on the surface. Cover classes are described at the bottom of Table 1.1. Analysis for cover class data was done using the midpoint of a class. Cover on the side slopes was assessed using a modified Daubenmire technique. This approach divides a $0.5 \mathrm{~m} 2$ rectangular plot frame into 50,1- dm2 quadrats, allowing for less than $1 \%$ cover resolution. Fifteen plots were located on the west side slope, five in each of three transects from the top of the slope to the bottom. On the north side, nine plots were located, with three in each of three transects from the top to the bottom of the slope. All plots were lumped to compare cover types $(n=24)$. Percent cover data were transformed by

$$
\operatorname{arcSin} \sqrt{\frac{\% \text { Cover }}{100}+0.5}
$$


before statistical analysis and when data were wide ranging with some values near zero (Steele and Torrie 1960). Because the cover values can be above $100 \%$ no transformation was applied when values were high. Shrub density was determined by counting all shrubs in each quadrat on the barrier surface. In each plot the number of shrubs in three age classes (new seedlings, midsize young, and old large) were counted. Shrub density and size/age structure was assessed. All shrubs were counted in each of 288 quadrats on the barrier surface. In each plot the number of shrubs in three age classes (new seedlings, midsize young, and old large) were counted.

\subsection{Results}

Plant information collected included a species list for the north (formerly irrigated) section and south (formerly non-irrigated) section of the barrier. Plant information was also collected on the north and west side-slopes. Shrub height, greatest canopy diameter, and the diameter at the center of the plant perpendicular to the greatest diameter were measured on 25 shrubs each from sections of the barrier. General assessments of shrub survival, re-sprouting, and recruitment were also made.

\subsubsection{Species Composition}

Sagebrush dominated the shrub cover of the Prototype Hanford Barrier. Figure 4.1 shows the surface in 15 years after establishment. Rabbitbrush is sparse on the barrier surface, with relatively few plants in either treatment (formerly-irrigated, and non-irrigated). These were found near the edges of the surface. In FY 2008, the vegetation was removed from the north half of the surface in a controlled burn (Ward et al. 2008; 2009).

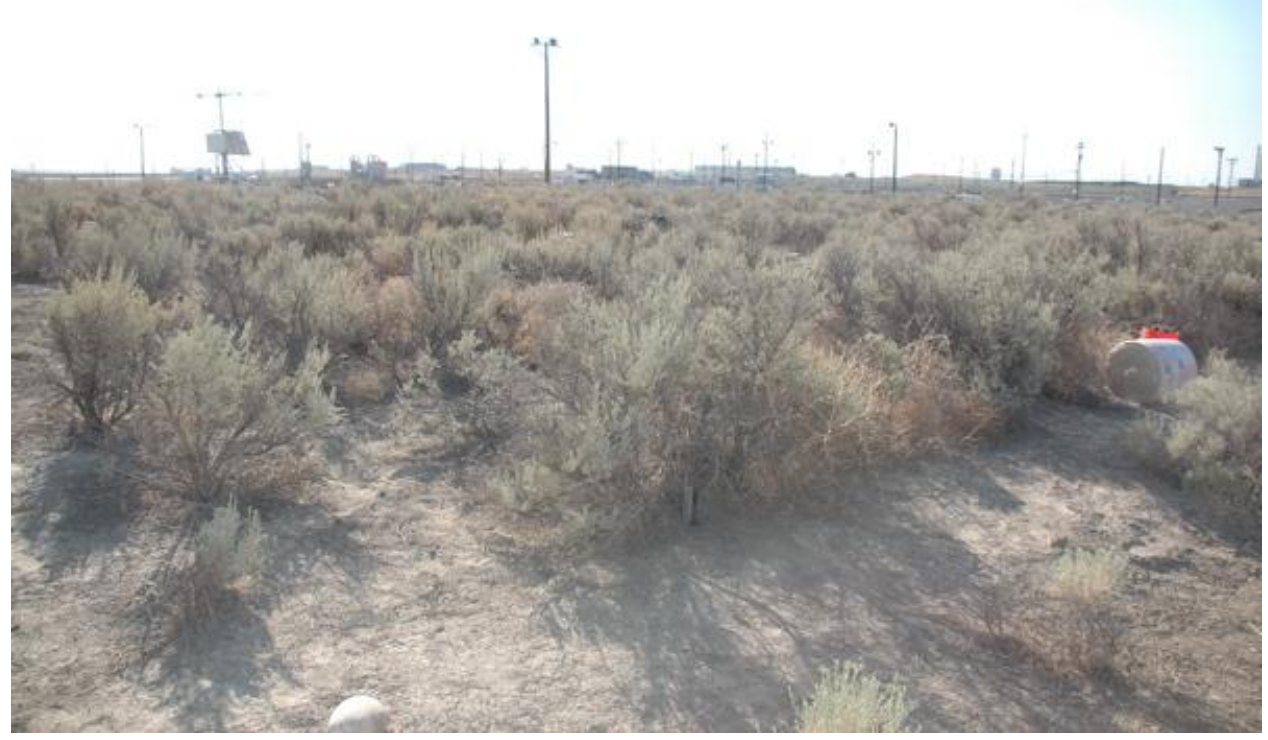

Figure 4.1. Prototype Hanford Barrier Cover Dominated by Artemisia tridentata in 2007, 15 Years After Establishment. 
After the fire on the formerly irrigated north half of the barrier sagebrush is no longer dominant and has been replaced by Salsola kali (Figure 4.2). Figure 4.3 compares the total number of annual and perennial species on the barrier surface from 1995 through 2009.

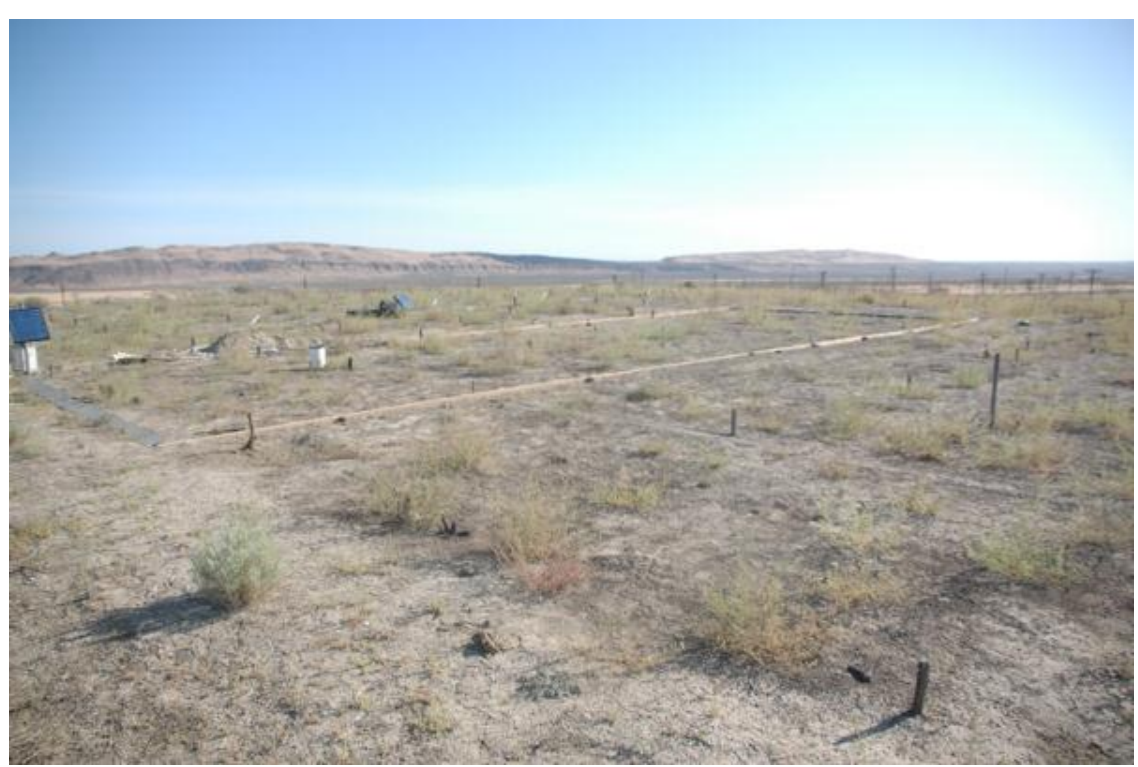

Figure 4.2. South (originally unirrigated) Section of Prototype Hanford Barrier Cover Dominated by Artemisia tridentata in 2009, 15 Years After Establishment.

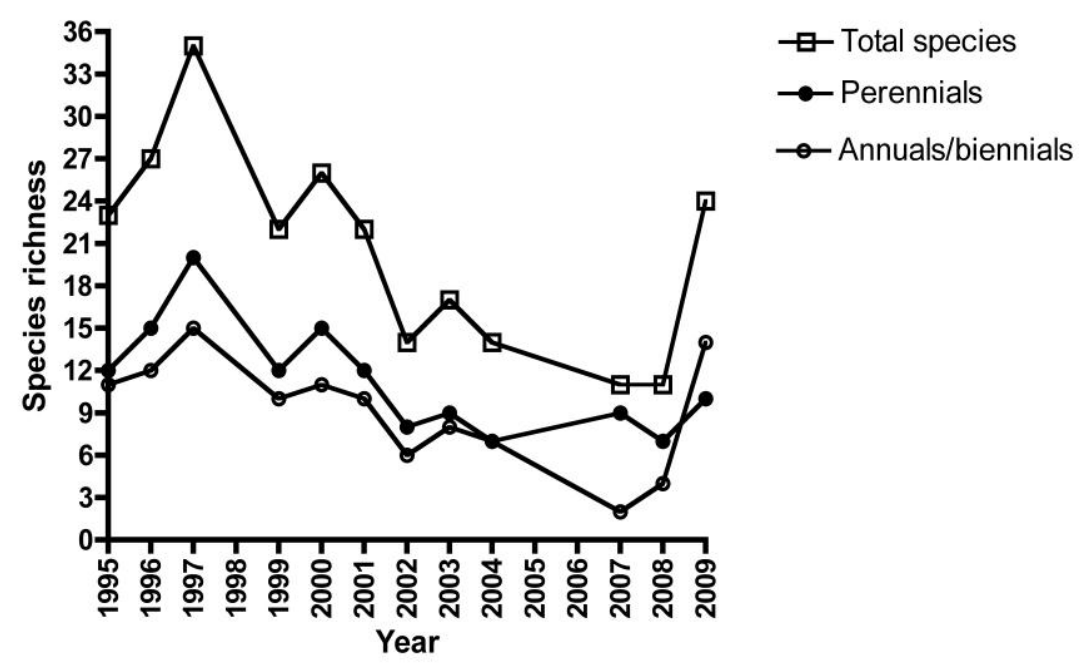

Figure 4.3. Temporal variation in the number of annual/biennials and perennial species including total species on the Prototype Hanford Barrier. 
Table 4.1 identifies the different species of vegetation on the burned and unburned treatments of the barrier. Table 4.2 compares the species identified on the barrier surface in 2009 against those identified from 1995 through 2008. Table 4.3 lists species on the barrier side slopes.

The species richness of the plant community on the prototype Hanford barrier has dropped from 35 in 1997 to 11 in 2008 just before the fire. Nearly one year after the fire, species richness increased to 15 in the unburned half of the surface and increased markedly to 24 species on the burned half of the surface. Species richness on the two side slopes was lower than in other areas (Table 4.3). Stephanomeria paniculata has never been present. Many of the species observed after the fire had not been observed for several years (Table 4.2). Some of these species may have resided in the seed bank waiting for a fire to create conditions conducive to germination and establishment.

The dominance of $A$. tridentata on the unburned half of the barrier surface may contribute to continued reductions in species richness on the surface and likely keep species richness low. Annual and biennial species are $53 \%$ in the unburned barrier surface, increasing to $58 \%$ on the burned half of the barrier. Similar species richness was found at the unburned $\mathrm{McGee}$ Ranch analog site that is also dominated by $A$. tridentata (Ward et al 2009). This is in contrast to a similar richness at the burned McGee Ranch analog site even though $A$. tridentata has very low cover. Side slope species richness remains relatively low being near the low end of species richness of the surface before the fire (Table 4.3).

\subsubsection{Soil Cryptogram}

Ward et al (2009) reported surveys of cryptogram crusts at four study sites including two analog sites at the McGee Ranch and the burned (north) half of the barrier and the unburned (south) half. No soil cryptogams were observed on the burned surface of the barrier. The unburned half of the barrier surface had seven species. There was only one soil lichen found at the McGee Ranch old fire site. On the unburned half of the barrier surface cryptogamic crust is well developed with seven species Figure 4.4), but likely to continue to change and become more diverse (Figure 4.5). Cryptogamic crust cover is now about $37.3 \%$ in the south (unburned half). The largest colony of thallus of Caloplaca tominii was about $60 \mathrm{~mm}$ in diameter. Assuming it initiated in 1994, its growth rate is about $4.6 \mathrm{~mm} \mathrm{y}^{-1}$. The darker elements of the surface in Figure 4.4 are likely a combination of moss, lichens, and blue-green algae. Cryptogamic crust is also well developed at the unburned McGee Ranch site with 12 species being identified. As shown in Table 4.4, soil cryptogam composition was quite variable on the unburned half of the surface.

\subsubsection{Ground Cover}

The mean, median, and mode cover classes for each cover type in the burned and unburned treatments of the barrier are in Table 4.5, Table 4.6, Table 4.7, and Table 4.8. The ranges are the cover classes as defined by Daubenmire (1959). Nearly one year after the fire the burned section now has significantly greater grass cover than the unburned section although grass cover is very low (Table 4.9). Shrub cover was significantly greater in the unburned than in the burned half of the barrier. Forb (mostly S. kali) cover is much higher in the burned area than in the unburned area. Soil cryptogam cover does not exist on the burned half of the barrier and is much higher in the unburned areas on the barrier. Litter is now much lower in the burned section compared with the unburned section. Bare ground cover is now higher 
Table 4.1. Plant species observed in 2009 on the Burned and Unburned Sections of the Barrier.

\begin{tabular}{|c|c|c|c|}
\hline Family & Species & $\begin{array}{c}\text { Formerly } \\
\text { irrigated } \\
\text { (burned) }\end{array}$ & $\begin{array}{c}\text { Non- } \\
\text { irrigated } \\
\text { (unburned) }\end{array}$ \\
\hline \multirow{9}{*}{ Asteraceae } & Achillea millifolium & $\mathrm{X}$ & \\
\hline & Artemisia tridentata & $\mathrm{X}$ & $\mathrm{X}$ \\
\hline & Centaurea diffusa & $\mathrm{X}$ & $\mathrm{X}$ \\
\hline & Chrysothamnus viscidiflorus & $\mathrm{X}$ & $\mathrm{X}$ \\
\hline & Ericameria nauseosa & $X$ & $\mathrm{X}$ \\
\hline & Lactuca serriola & $\mathrm{X}$ & \\
\hline & Machaeranthera canescens & $\mathrm{X}$ & $\mathrm{X}$ \\
\hline & Stephanomeria paniculata & $\mathrm{X}$ & \\
\hline & Tragopogon dubius & $\mathrm{X}$ & \\
\hline Boraginaceae & Amsinckia lycopsoides & $X$ & $\mathrm{X}$ \\
\hline \multirow{2}{*}{ Brassicaceae } & Descurainia pinnata & $\mathrm{X}$ & \\
\hline & Sisymbrium altissimum & $\mathrm{X}$ & $\mathrm{X}$ \\
\hline \multirow{2}{*}{ Chenopodiaceae } & Chenopodium leptophyllum & $X$ & \\
\hline & Salsola kali & $\mathrm{X}$ & $\mathrm{X}$ \\
\hline \multirow{2}{*}{ Fabaceae } & Astragalus caricinus & $\mathrm{X}$ & \\
\hline & Melilotus officinalis & $\mathrm{X}$ & \\
\hline Geraniaceae & Erodium cicutarium & $\mathrm{X}$ & $\mathrm{X}$ \\
\hline \multirow{6}{*}{ Poaceae } & Bromus tectorum & $\mathrm{X}$ & $\mathrm{X}$ \\
\hline & Elymus wawawaiensis & $\mathrm{X}$ & $\mathrm{X}$ \\
\hline & Poa ampla & $\mathrm{X}$ & $\mathrm{X}$ \\
\hline & Poa bulbosa & $\mathrm{X}$ & $\mathrm{X}$ \\
\hline & Poa secunda & $\mathrm{X}$ & $\mathrm{X}$ \\
\hline & Vulpia microstachys & $\mathrm{X}$ & $\mathrm{X}$ \\
\hline \multirow[t]{2}{*}{ Verbenaceae } & Verbena bracteata & $\mathrm{X}$ & \\
\hline & $\begin{array}{l}\text { Total Number of Species } \\
\text { Present }\end{array}$ & 24 & 15 \\
\hline
\end{tabular}


Table 4.2. Plant species found in the Columbia Basin. Species type are "N" = native, "A" = alien, "AF" = annual forb, "AG" = annual grass, "BF" = biennial forb, "PF" = perennial forb, "PG" = perennial grass, "S" = shrub, "R" = seeded or planted species

\begin{tabular}{|c|c|c|c|c|c|c|c|c|c|c|c|c|c|c|c|c|}
\hline $\begin{array}{l}\text { Family } \\
\text { Species }\end{array}$ & Common Name & $\begin{array}{l}\text { Species } \\
\text { Type }\end{array}$ & 完 & है & : & : & 芌 & 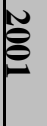 & 䓂 & שֶ & & & 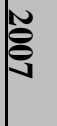 & 尺్̊ & & క \\
\hline \multicolumn{17}{|l|}{ Boraginaceae } \\
\hline $\begin{array}{l}\text { Amsinckia } \\
\text { lycopsoides }\end{array}$ & Fiddleneck & $\mathrm{N}, \mathrm{AF}$ & $\mathrm{x}$ & $\mathrm{x}$ & $\mathrm{X}$ & $\mathrm{x}$ & $\mathrm{x}$ & $\mathrm{x}$ & $\mathrm{x}$ & $\mathrm{x}$ & & $\mathrm{x}$ & & & & $\mathrm{x}$ \\
\hline Caryophyllaceae & & & & & & & & & & & & & & & & \\
\hline $\begin{array}{l}\text { Holosteum } \\
\text { umbellatum }\end{array}$ & Jagged chickweed & A,AF & & & & $\mathrm{x}$ & $\mathrm{x}$ & $\mathrm{x}$ & $\mathrm{x}$ & $\mathrm{x}$ & & & & & & \\
\hline \multicolumn{17}{|l|}{ Chenopodiaceae } \\
\hline $\begin{array}{l}\text { Chenopodium } \\
\text { leptophyllum }\end{array}$ & Slimleaf goosefoot & $\mathrm{N}, \mathrm{AF}$ & $\mathrm{x}$ & $\mathrm{x}$ & $\mathrm{x}$ & & & & & & & & & & & $\mathrm{x}$ \\
\hline Salsola kali & Tumbleweed & $\mathrm{A}, \mathrm{AF}$ & $\mathrm{x}$ & $\mathrm{x}$ & $\mathrm{x}$ & $\mathrm{x}$ & $\mathrm{x}$ & $\mathrm{x}$ & & $\mathrm{x}$ & & $\mathrm{x}$ & & & & $\mathrm{x}$ \\
\hline \multicolumn{17}{|l|}{ Compositae } \\
\hline Achillea millefolium & Yarrow & $\mathrm{N}, \mathrm{PF}$ & $\mathrm{x}$ & & $\mathrm{x}$ & $\mathrm{x}$ & $\mathrm{x}$ & $\mathrm{x}$ & & & & & $\mathrm{x}$ & & & $\mathrm{x}$ \\
\hline $\begin{array}{l}\text { Ambrosia } \\
\text { acanthicarpa }\end{array}$ & Bur ragweed & $\mathrm{N}, \mathrm{AF}$ & $\mathrm{x}$ & & $\mathrm{x}$ & & $\mathrm{x}$ & & & & & & & & & \\
\hline $\begin{array}{l}\text { Artemisia } \\
\text { tridentata }\end{array}$ & $\begin{array}{l}\text { Wyoming big } \\
\text { sagebrush }\end{array}$ & $\mathrm{N}, \mathrm{R}, \mathrm{S}$ & $\mathrm{x}$ & $\mathrm{x}$ & $\mathrm{x}$ & $\mathrm{x}$ & $\mathrm{x}$ & $\mathrm{x}$ & $\mathrm{x}$ & $x$ & & $\mathrm{x}$ & $\mathrm{x}$ & & & $\mathrm{x}$ \\
\hline Centaurea diffusa & Diffuse knapweed & $\mathrm{A}, \mathrm{BF}$ & & & & & & & & & & & $\mathrm{x}$ & & & $\mathrm{x}$ \\
\hline $\begin{array}{l}\text { Chrysothamnus } \\
\text { viscidiflorus }\end{array}$ & Green rabbitbrush & $\mathrm{N}, \mathrm{S}$ & & & $\mathrm{x}$ & & & & & & & & $\mathrm{x}$ & & & $\mathrm{x}$ \\
\hline Conyza canadensis & Horseweed & $\mathrm{N}, \mathrm{AF}$ & & & $\mathrm{x}$ & & & & & & & & & & & \\
\hline $\begin{array}{c}\text { Ericameria } \\
\text { nauseosa }\end{array}$ & Gray rabbitbrush & $\mathrm{N}, \mathrm{R}, \mathrm{S}$ & $\mathrm{x}$ & $\mathrm{x}$ & $\mathrm{x}$ & $\mathrm{x}$ & $\mathrm{x}$ & $\mathrm{x}$ & $\mathrm{x}$ & $\mathrm{x}$ & & $\mathrm{x}$ & $\mathrm{x}$ & & & $\mathrm{x}$ \\
\hline
\end{tabular}




\begin{tabular}{|c|c|c|c|c|c|c|c|c|c|c|c|c|c|c|c|}
\hline $\begin{array}{l}\text { Family } \\
\text { Species }\end{array}$ & Common Name & $\begin{array}{l}\text { Species } \\
\text { Type }\end{array}$ & 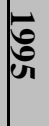 & م. & 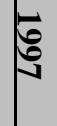 & 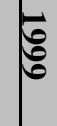 & 气 & $\tilde{\hat{\theta}}$ & & 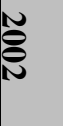 & 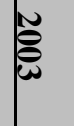 & 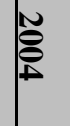 & 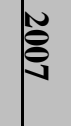 & 苚 & $F$ \\
\hline Erigeron spp. & Fleabane & $\mathrm{N}, \mathrm{PF}$ & & & & & & & & $\mathrm{x}$ & $\mathrm{x}$ & & & & \\
\hline Lactuca serriola & Prickly lettuce & $\mathrm{A}, \mathrm{AF}$ & $\mathrm{x}$ & $\mathrm{x}$ & $\mathrm{x}$ & $\mathrm{x}$ & $\mathrm{x}$ & & & & $\mathrm{x}$ & $\mathrm{x}$ & & & \\
\hline $\begin{array}{l}\text { Machaeranthera } \\
\text { canescens }\end{array}$ & Hoary aster & $\begin{array}{l}\mathrm{N} \\
\mathrm{B} / \mathrm{PF}\end{array}$ & & $\mathrm{x}$ & $\mathrm{x}$ & $\mathrm{x}$ & $\mathrm{x}$ & 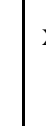 & $x$ & & $\mathrm{x}$ & $\mathrm{x}$ & $\mathrm{x}$ & $\mathrm{x}$ & \\
\hline $\begin{array}{l}\text { Stephanomeria } \\
\text { paniculata }\end{array}$ & Tufted wirelettuce & $\mathrm{N}, \mathrm{AF}$ & & & & & & & & & & & & & \\
\hline Tragopogon dubius & Salsify & $\mathrm{A}, \mathrm{AF}$ & & $\mathrm{x}$ & $\mathrm{x}$ & $\mathrm{x}$ & $x$ & $x$ & $x$ & & & $\mathrm{x}$ & & & \\
\hline \multicolumn{16}{|l|}{ Convolvulaceae } \\
\hline $\begin{array}{l}\text { Convolvulus } \\
\text { arvensis }\end{array}$ & Field bindweed & A,PF & & $\mathrm{x}$ & $\mathrm{x}$ & & & & & & & & & & \\
\hline \multicolumn{16}{|l|}{ Cruciferae } \\
\hline Cardaria draba & White top & A,PF & & $\mathrm{x}$ & $\mathrm{x}$ & $\mathrm{x}$ & $x$ & & & & & & & & \\
\hline Chorispora tenella & Blue mustard & $\mathrm{A}, \mathrm{AF}$ & $\mathrm{x}$ & & $\mathrm{x}$ & & & & & & & & & & \\
\hline $\begin{array}{l}\text { Descurainia } \\
\text { pinnata }\end{array}$ & $\begin{array}{l}\text { Pinnate } \\
\text { tansymustard }\end{array}$ & $\mathrm{N}, \mathrm{AF}$ & $\mathrm{x}$ & $\mathrm{x}$ & $\mathrm{x}$ & & & & & & & & & & \\
\hline Draba verna & $\begin{array}{l}\text { Spring-whitlow } \\
\text { grass }\end{array}$ & $\mathrm{A}, \mathrm{AF}$ & $\mathrm{x}$ & $\mathrm{x}$ & $\mathrm{x}$ & $\mathrm{x}$ & $x$ & sina & $x$ & $\mathrm{x}$ & & & & & \\
\hline $\begin{array}{l}\text { Sisymbrium } \\
\text { altissimum }\end{array}$ & Tumblemustard & $\mathrm{A}, \mathrm{AF}$ & $\mathrm{x}$ & $\mathrm{x}$ & $\mathrm{x}$ & & $x$ & & & & $\mathrm{x}$ & & & & \\
\hline \multicolumn{16}{|l|}{ Geraniaceae } \\
\hline Erodium cicutarium & Redstem storksbill & $\mathrm{A}, \mathrm{AF}$ & $\mathrm{x}$ & $\mathrm{x}$ & $\mathrm{x}$ & $\mathrm{x}$ & $x$ & s & $x$ & $\mathrm{x}$ & $\mathrm{x}$ & $\mathrm{x}$ & & & \\
\hline \multicolumn{16}{|l|}{ Graminae } \\
\hline $\begin{array}{c}\text { Achnatherum } \\
\text { hymenoides }\end{array}$ & Indian rice grass & $\begin{array}{l}\mathrm{N}, \mathrm{R} \\
\mathrm{PG}\end{array}$ & $\mathrm{x}$ & $\mathrm{x}$ & $\mathrm{x}$ & & & & $x$ & & & & & & \\
\hline Agropyron & Crested wheatgrass & A,PG & & $\mathrm{x}$ & $\mathrm{x}$ & $\mathrm{x}$ & & & & & & & & & \\
\hline
\end{tabular}




\begin{tabular}{|c|c|c|c|c|c|c|c|c|c|c|c|c|c|c|}
\hline $\begin{array}{l}\text { Family } \\
\text { Species }\end{array}$ & Common Name & $\begin{array}{l}\text { Species } \\
\text { Type }\end{array}$ & 完 & مे & ڤֶ: & : & 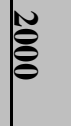 & $\tilde{\tilde{O}}$ & 荅 & 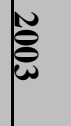 & 薝 & 䓂 & 芯 & 彀 \\
\hline \multicolumn{15}{|l|}{ cristatum } \\
\hline $\begin{array}{l}\text { Agropyron } \\
\text { dasytachyum }\end{array}$ & $\begin{array}{l}\text { Thickspike } \\
\text { wheatgrass }\end{array}$ & $\begin{array}{l}\mathrm{N}, \mathrm{R} \\
\mathrm{PG}\end{array}$ & $\mathrm{x}$ & $\mathrm{x}$ & $\mathrm{x}$ & & & & & & & & & \\
\hline $\begin{array}{l}\text { Agropyron } \\
\text { intermedium }\end{array}$ & $\begin{array}{l}\text { Intermediate } \\
\text { wheatgrass }\end{array}$ & A,PG & & $\mathrm{x}$ & $\mathrm{x}$ & & $\mathrm{x}$ & $\mathrm{x}$ & $\mathrm{x}$ & $\mathrm{x}$ & & & & \\
\hline Bromus tectorum & Cheatgrass & A,AG & $\mathrm{x}$ & $\mathrm{x}$ & $\mathrm{x}$ & $\mathrm{x}$ & $\mathrm{x}$ & $\mathrm{x}$ & $\mathrm{x}$ & $\mathrm{x}$ & $\mathrm{x}$ & $\mathrm{x}$ & $\mathrm{x}$ & s \\
\hline Elymus elymoides & Squirreltail & $\mathrm{N}, \mathrm{R}, \mathrm{PG}$ & $\mathrm{x}$ & & & & $\mathrm{x}$ & & & & & & & \\
\hline $\begin{array}{l}\text { Elymus } \\
\text { wawawaiensis }\end{array}$ & $\begin{array}{l}\text { Snake River } \\
\text { wheatgrass }\end{array}$ & $\begin{array}{l}\mathrm{N}, \mathrm{R}, \\
\mathrm{PG}\end{array}$ & $\mathrm{x}$ & $\mathrm{x}$ & $\mathrm{X}$ & $\mathrm{x}$ & $\mathrm{x}$ & $\mathrm{x}$ & $\mathrm{x}$ & $\mathrm{x}$ & $\mathrm{x}$ & $\mathrm{x}$ & $\mathrm{x}$ & , \\
\hline $\begin{array}{l}\text { Hesperostipa } \\
\text { comata }\end{array}$ & $\begin{array}{l}\text { Needle-and-thread } \\
\text { grass }\end{array}$ & $\begin{array}{l}\mathrm{N}, \mathrm{R} \\
\mathrm{PG}\end{array}$ & $\mathrm{x}$ & & $\mathrm{X}$ & & & & & & & & & \\
\hline Poa ampla & $\begin{array}{l}\text { Sherman big } \\
\text { bluegrass }\end{array}$ & R,PG & $\mathrm{x}$ & $\mathrm{x}$ & $\mathrm{X}$ & $\mathrm{x}$ & $\mathrm{x}$ & $\mathrm{x}$ & $\mathrm{x}$ & $\mathrm{x}$ & $\mathrm{x}$ & $\mathrm{x}$ & $\mathrm{x}$ & 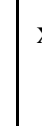 \\
\hline Poa bulbosa & Bulbous bluegrass & A,PG & $\mathrm{x}$ & $\mathrm{x}$ & $\mathrm{X}$ & $\mathrm{x}$ & $\mathrm{x}$ & $\mathrm{x}$ & $\mathrm{x}$ & $\mathrm{x}$ & $\mathrm{x}$ & $\mathrm{x}$ & $\mathrm{x}$ & 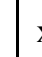 \\
\hline Poa secunda & $\begin{array}{l}\text { Sandberg's } \\
\text { bluegrass }\end{array}$ & $\begin{array}{l}\text { N, R, } \\
\text { PG }\end{array}$ & $\mathrm{x}$ & $\mathrm{x}$ & $\mathrm{X}$ & $\mathrm{x}$ & $\mathrm{x}$ & $\mathrm{x}$ & $\mathrm{x}$ & $\mathrm{x}$ & $\mathrm{x}$ & $\mathrm{x}$ & $\mathrm{x}$ & 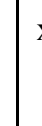 \\
\hline Triticum aestivum & Wheat & $\mathrm{A}, \mathrm{AG}$ & $\mathrm{x}$ & & & & & & & & & & & \\
\hline $\begin{array}{l}\text { Vulpia } \\
\text { microstachys }\end{array}$ & Small fescue & $\mathrm{N}, \mathrm{AG}$ & & & & & & $\mathrm{x}$ & $\mathrm{x}$ & & $\mathrm{x}$ & & & 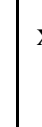 \\
\hline \multicolumn{15}{|l|}{ Hydrophyllaceae } \\
\hline Phacelia linearis & Linear phacelia & $\mathrm{N}, \mathrm{AF}$ & $\mathrm{x}$ & & & & & & & & & & & \\
\hline \multicolumn{15}{|l|}{ Laminaceae } \\
\hline $\begin{array}{l}\text { Agastache } \\
\text { occidentalis }\end{array}$ & Western horsemint & $\mathrm{N}, \mathrm{PF}$ & & & & $\mathrm{x}$ & & & & & & & & \\
\hline Leguminosae & & & & & & & & & & & & & & \\
\hline
\end{tabular}




\begin{tabular}{|c|c|c|c|c|c|c|c|c|c|c|c|c|c|c|}
\hline $\begin{array}{l}\text { Family } \\
\text { Species }\end{array}$ & Common Name & $\begin{array}{l}\text { Species } \\
\text { Type }\end{array}$ & 茪 & مٌ & tio & 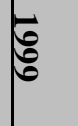 & 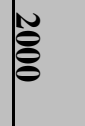 & $\tilde{\tilde{E}}$ & 高 & 峞 & 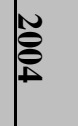 & 菖 & 高 & 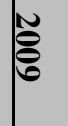 \\
\hline Astragalus spp & Milkvetch & $\mathrm{N}, \mathrm{PF}$ & & & $\mathrm{x}$ & $\mathrm{x}$ & $\mathrm{x}$ & $\mathrm{x}$ & & & & & & \\
\hline $\begin{array}{l}\text { Astragalus } \\
\text { caricinus }\end{array}$ & $\begin{array}{l}\text { Buckwheat } \\
\text { milkvetch }\end{array}$ & $\mathrm{N}, \mathrm{PF}$ & & & & & $\mathrm{x}$ & & & & & $\mathrm{x}$ & & $\mathrm{x}$ \\
\hline Lupinus pusillus & Rusty lupine & $\mathrm{N}, \mathrm{AF}$ & & & $\mathrm{x}$ & & & & & & & & & \\
\hline Melilotus officinalis & Yellow Sweet clover & A,PF & & $\mathrm{x}$ & $\mathrm{x}$ & $\mathrm{x}$ & $\mathrm{x}$ & $\mathrm{x}$ & & & & & & $\mathrm{x}$ \\
\hline \multicolumn{15}{|l|}{ Malvaceae } \\
\hline $\begin{array}{l}\text { Sphaeralcea } \\
\text { munroana }\end{array}$ & $\begin{array}{l}\text { Munro's } \\
\text { globemallow }\end{array}$ & $\mathrm{N}, \mathrm{PF}$ & & $\mathrm{x}$ & $x$ & $\mathrm{x}$ & $\mathrm{x}$ & $\mathrm{x}$ & & $\mathrm{x}$ & $\mathrm{x}$ & & & \\
\hline \multicolumn{15}{|l|}{ Onagraceae } \\
\hline $\begin{array}{l}\text { Epilobium } \\
\text { paniculatum }\end{array}$ & Tall willowherb & $\mathrm{N}, \mathrm{AF}$ & & $\mathrm{x}$ & $\mathrm{x}$ & $\mathrm{x}$ & $\mathrm{x}$ & $\mathrm{x}$ & & & & & & \\
\hline \multicolumn{15}{|l|}{ Verbenaceae } \\
\hline Verbena bracteata & Bracted verbena & $\mathrm{N}, \mathrm{PF}$ & & $\mathrm{x}$ & $\mathrm{x}$ & & & & & & & & & $\mathrm{x}$ \\
\hline \multicolumn{2}{|c|}{ Number of Species Present } & & 23 & 27 & 35 & 22 & 26 & 22 & 14 & 17 & 14 & 12 & 11 & 24 \\
\hline
\end{tabular}


Table 4.3. Plant Species Observed in 2009 on the West and North Side-slopes of the Barrier

\begin{tabular}{|c|c|c|c|}
\hline Family & Species & West Slope & North Slope \\
\hline \multirow{7}{*}{ Asteraceae } & Achillea millefolium & & $\mathrm{X}$ \\
\hline & Artemisia tridentata & $\mathrm{X}$ & $\mathrm{X}$ \\
\hline & Ericameria nauseosa & $\mathrm{X}$ & $\mathrm{X}$ \\
\hline & Centaurea diffusa & $\mathrm{X}$ & \\
\hline & Chrysothamnus viscidiflorus & $\mathrm{X}$ & $\mathrm{X}$ \\
\hline & Lactuca serriola & $\mathrm{X}$ & \\
\hline & Machaeranthera canescens & $\mathrm{X}$ & $\mathrm{X}$ \\
\hline Carhophyllaceae & Holosteum umbellatum & $\mathrm{X}$ & $\mathrm{X}$ \\
\hline Chenopodiacea & Salsola kali & $\mathrm{X}$ & \\
\hline Fabaceae & Astragalus caricinus & & $\mathrm{X}$ \\
\hline Geraniaceae & Erodium cicutarium & $\mathrm{X}$ & \\
\hline \multirow{4}{*}{ Poaceae } & Bromus tectorum & $\mathrm{X}$ & $\mathrm{X}$ \\
\hline & Elymus wawawaiensis & $\mathrm{X}$ & $\mathrm{X}$ \\
\hline & Poa bulbosa & $\mathrm{X}$ & $\mathrm{X}$ \\
\hline & Poa secunda & $\mathrm{X}$ & $\mathrm{X}$ \\
\hline & Total Number of Species Present: & 13 & 11 \\
\hline
\end{tabular}




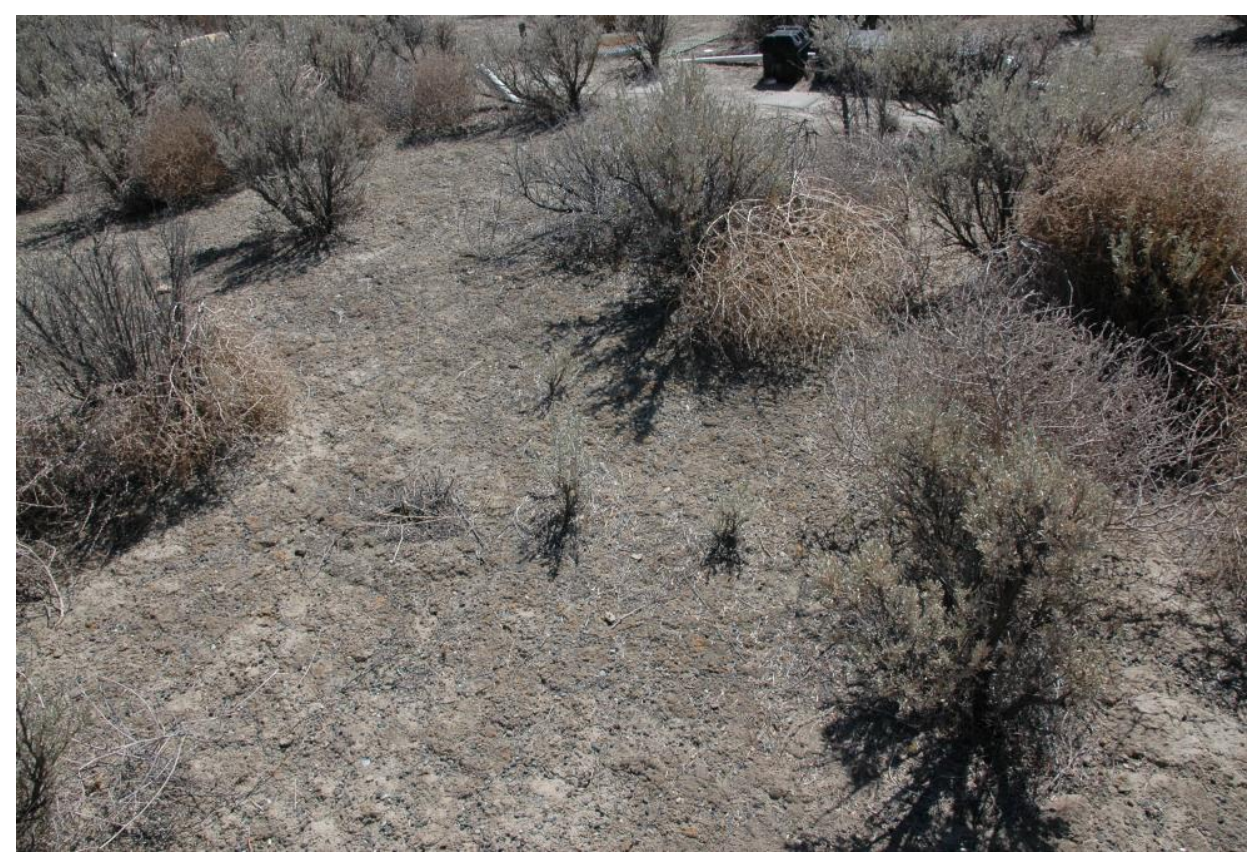

Figure 4.4. Cryptogamic Crust Covering Most of the Soil Surface. Bright Patches on the Surface are Bare Soil.

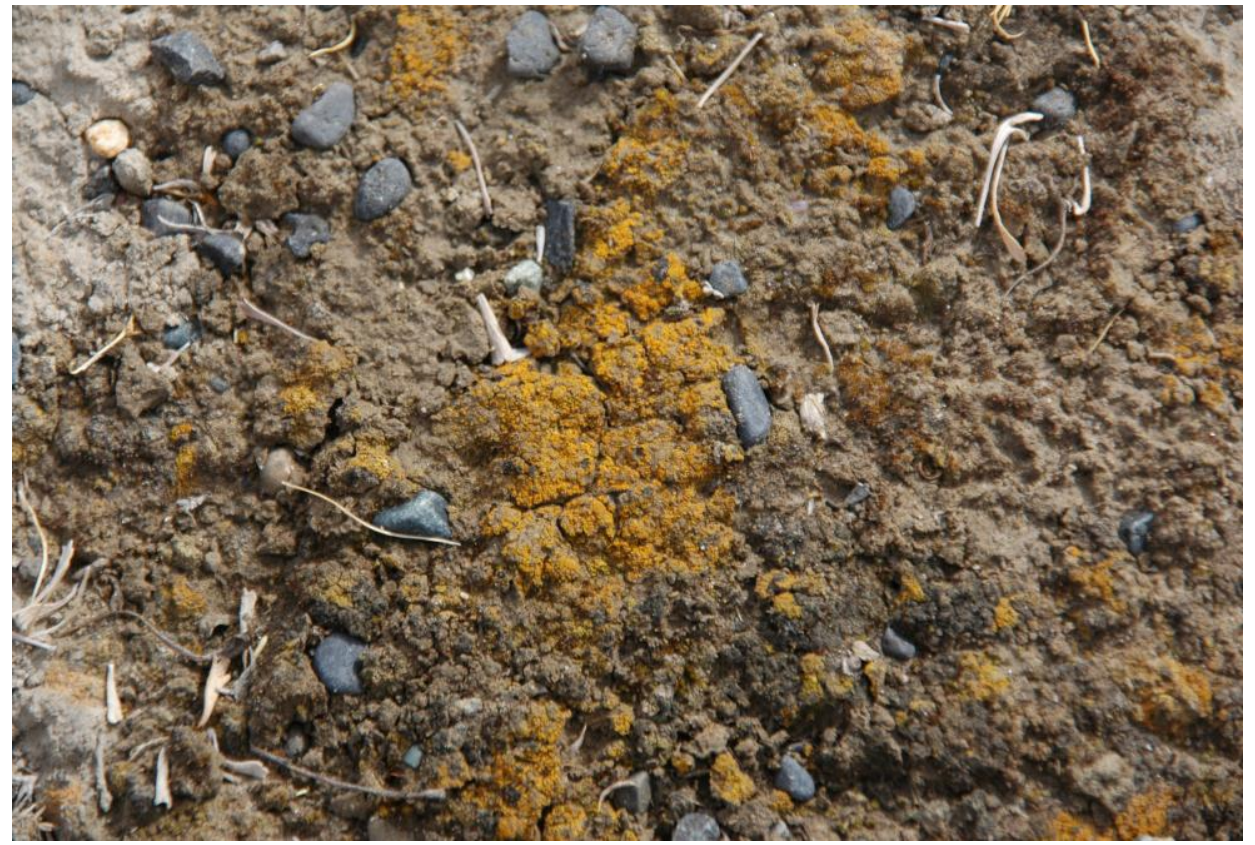

Figure 4.5. Soil cryptogams. The Orange Lichen is Caloplaca tominii and the Moss is Bryum cf. caespiticium (Link et al. 2000). 
Table 4.4. Lichens and mosses occurring on soils of the unburned half of the barrier.

\begin{tabular}{|l|}
\hline Lichens \\
\hline Caloplaca tominii Savicz \\
\hline Candelaria concolor (Dickson) Stein \\
\hline Candelariella terrigena Rasanen \\
\hline Physconia isidiigera (Zahlbr.) Essl. \\
\hline Psora luridella (Tuck.) Fink \\
\hline Mosses \\
\hline Bryum argenteum Hedw. \\
\hline Bryum cf caespiticium Hedw. (sterile) \\
\hline Syntrichia ruralis var. papillosissima (Copp.) Loeske. \\
\hline
\end{tabular}


Table 4.5. Median, Mode, and Mean Percent Cover Classes Ranges for Grass

\begin{tabular}{|c|c|c|c|c|c|c|}
\hline \multicolumn{2}{|c|}{ Cover Class } & Treatment & Water Year & Median & Mode & Mean \\
\hline \multirow{20}{*}{\multicolumn{2}{|c|}{ Grass }} & \multirow{10}{*}{ Burned } & 1996 & $25-50$ & $5-25$ & \\
\hline & & & 1997 & $50-75$ & $50-75$ & \\
\hline & & & 1999 & $75-95$ & $75-95$ & $50-75$ \\
\hline & & & 2000 & $75-95$ & $75-95$ & $50-75$ \\
\hline & & & 2001 & $75-95$ & $75-95$ & $25-50$ \\
\hline & & & 2002 & $5-25$ & $5-25$ & $5-25$ \\
\hline & & & 2003 & $5-25$ & $5-25$ & $5-25$ \\
\hline & & & 2004 & $5-25$ & $5-25$ & $25-50$ \\
\hline & & & 2007 & $0-5$ & $0-5$ & $5-25$ \\
\hline & & & 2009 & $0-5$ & $0-5$ & $0-5$ \\
\hline & & \multirow{10}{*}{ Unburned } & 1996 & $5-25$ & $5-25$ & \\
\hline & & & 1997 & $25-50$ & $25-50$ & \\
\hline & & & 1999 & $25-50$ & $25-50$ & $25-50$ \\
\hline & & & 2000 & $5-25$ & $5-25$ & $25-50$ \\
\hline & & & 2001 & $5-25$ & $5-25$ & $5-25$ \\
\hline & & & 2002 & $0-5$ & $0-5$ & $0-5$ \\
\hline & & & 2003 & $5-25$ & $0-5$ & $5-25$ \\
\hline & & & 2004 & $0-5$ & $0-5$ & $5-25$ \\
\hline & & & 2007 & $0-5$ & $0-5$ & $0-5$ \\
\hline & & & 2009 & $0-5$ & $0-5$ & $0-5$ \\
\hline Class & 1 & 2 & 3 & 4 & 5 & 6 \\
\hline Percent Cover & 0 to 5 & 5 to 25 & 25 to 50 & 50 to 75 & 75 to 95 & 95 to 100 \\
\hline Midpoint & 2.5 & 15 & 37.5 & 62.5 & 85 & 97.5 \\
\hline
\end{tabular}


Table 4.6. Median, Mode, and Mean Percent Cover Classes Ranges for Shrubs

\begin{tabular}{|c|c|c|c|c|c|c|}
\hline \multicolumn{2}{|c|}{ Cover Class } & Treatment & Water Year & Median & Mode & Mean \\
\hline \multirow{20}{*}{\multicolumn{2}{|c|}{ Shrub }} & \multirow{10}{*}{ Burned } & 1996 & $0-5$ & $0-5$ & \\
\hline & & & 1997 & $25-50$ & $25-50$ & \\
\hline & & & 1999 & $25-50$ & $25-50$ & $25-50$ \\
\hline & & & 2000 & $50-75$ & $50-75$ & $25-50$ \\
\hline & & & 2001 & $25-50$ & $25-50$ & $25-50$ \\
\hline & & & 2002 & $25-50$ & $25-50$ & $25-50$ \\
\hline & & & 2003 & $25-50$ & $25-50$ & $25-50$ \\
\hline & & & 2004 & $25-50$ & $25-50$ & $25-50$ \\
\hline & & & 2007 & $25-50$ & $25-50$ & $25-50$ \\
\hline & & & 2009 & $0-5$ & $0-5$ & $0-5$ \\
\hline & & \multirow{10}{*}{ Unburned } & 1996 & $0-5$ & $0-5$ & \\
\hline & & & 1997 & $25-50$ & $25-50$ & \\
\hline & & & 1999 & $25-50$ & $25-50$ & $25-50$ \\
\hline & & & 2000 & $25-50$ & $25-50$ & $25-50$ \\
\hline & & & 2001 & $25-50$ & $25-50$ & $25-50$ \\
\hline & & & 2002 & $5-25$ & $5-25$ & $5-25$ \\
\hline & & & 2003 & $25-50$ & $25-50$ & $25-50$ \\
\hline & & & 2004 & $25-50$ & $25-50$ & $25-50$ \\
\hline & & & 2007 & $25-50$ & $25-50$ & $25-50$ \\
\hline & & & 2009 & $25-50$ & $25-50$ & $25-50$ \\
\hline Class & 1 & 2 & 3 & 4 & 5 & 6 \\
\hline Percent Cover & 0 to 5 & 5 to 25 & 25 to 50 & 50 to 75 & 75 to 95 & 95 to 100 \\
\hline Midpoint & 2.5 & 15 & 37.5 & 62.5 & 85 & 97.5 \\
\hline
\end{tabular}


Table 4.7. Median, Mode, and Mean Percent Cover Classes Ranges for Litter

\begin{tabular}{|c|c|c|c|c|c|c|}
\hline Cover & Class & Treatment & Water Year & Median & Mode & Mean \\
\hline & & & 1996 & $5-25$ & $5-25$ & \\
\hline & & & 1997 & $50-75$ & $50-75$ & \\
\hline & & & 1999 & $75-95$ & $95-100$ & $75-95$ \\
\hline & & & 2000 & $75-95$ & $75-95$ & $50-75$ \\
\hline & & & 2001 & $25-50$ & $25-50$ & $50-75$ \\
\hline & & Burned & 2002 & $50-75$ & $25-50$ & $50-75$ \\
\hline & & & 2003 & $25-50$ & $25-50$ & $25-50$ \\
\hline & & & 2004 & $50-75$ & $50-75$ & $50-75$ \\
\hline & & & 2007 & $5-25$ & $5-25$ & $25-50$ \\
\hline & & & 2009 & $0-5$ & $5-25$ & $5-25$ \\
\hline Litter & & & 1996 & $5-25$ & $5-25$ & \\
\hline & & & 1997 & $25-50$ & $25-50$ & \\
\hline & & & 1999 & $50-75$ & $50-75$ & $50-75$ \\
\hline & & & 2000 & $25-50$ & $25-50$ & $25-50$ \\
\hline & & & 2001 & $25-50$ & $5-25$ & $25-50$ \\
\hline & & Unburned & 2002 & $25-50$ & $25-50$ & $25-50$ \\
\hline & & & 2003 & $5-25$ & $5-25$ & $5-25$ \\
\hline & & & 2004 & $25-50$ & $25-50$ & $25-50$ \\
\hline & & & 2007 & $5-25$ & $5-25$ & $25-50$ \\
\hline & & & 2009 & $25-50$ & $25-50$ & $25-50$ \\
\hline Class & 1 & 2 & 3 & 4 & 5 & 6 \\
\hline Percent Cover & 0 to 5 & 5 to 25 & 25 to 50 & 50 to 75 & 75 to 95 & 95 to 100 \\
\hline Midpoint & 2.5 & 15 & 37.5 & 62.5 & 85 & 97.5 \\
\hline
\end{tabular}


Table 4.8. Median, Mode, and Mean Percent Cover Classes Ranges for Bare Ground

\begin{tabular}{|c|c|c|c|c|c|c|}
\hline Cover & Class & Treatment & Water Year & Median & Mode & Mean \\
\hline & & & 1996 & $5-25$ & $5-25$ & \\
\hline & & & 1997 & $5-25$ & $25-50$ & \\
\hline & & & 1999 & $5-25$ & $0-5$ & $5-25$ \\
\hline & & & 2000 & $5-25$ & $5-25$ & $5-25$ \\
\hline & & D & 2001 & $5-25$ & $5-25$ & $5-25$ \\
\hline & & Burned & 2002 & $25-50$ & $25-50$ & $25-50$ \\
\hline & & & 2003 & $50-75$ & $50-75$ & $25-50$ \\
\hline & & & 2004 & $25-50$ & $50-75$ & $25-50$ \\
\hline & & & 2007 & $50-75$ & $50-75$ & $50-75$ \\
\hline & & & 2009 & $75-95$ & $75-95$ & $75-95$ \\
\hline Bare Ground & & & 1996 & $5-25$ & $5-25$ & \\
\hline & & & 1997 & $25-50$ & $25-50$ & \\
\hline & & & 1999 & $5-25$ & $5-25$ & $25-50$ \\
\hline & & & 2000 & $25-50$ & $50-75$ & $25-50$ \\
\hline & & I Th & 2001 & $25-50$ & $25-50$ & $25-50$ \\
\hline & & Unburned & 2002 & $25-50$ & $25-50$ & $25-50$ \\
\hline & & & 2003 & $50-75$ & $75-95$ & $50-75$ \\
\hline & & & 2004 & $50-75$ & $50-75$ & $50-75$ \\
\hline & & & 2007 & $50-75$ & $50-75$ & $50-75$ \\
\hline & & & 2009 & $50-75$ & $50-75$ & $50-75$ \\
\hline Class & 1 & 2 & 3 & 4 & 5 & 6 \\
\hline Percent Cover & 0 to 5 & 5 to 25 & 25 to 50 & 50 to 75 & 75 to 95 & 95 to 100 \\
\hline Midpoint & 2.5 & 15 & 37.5 & 62.5 & 85 & 97.5 \\
\hline
\end{tabular}


Table 4.9. Mean percent cover ( \pm 1 sem) of plant species and other categories observed in 2009

\begin{tabular}{|c|c|c|}
\hline Species & Barrier burn & Barrier unburned \\
\hline Achillea millifolium & $0.02 \pm 0.02$ & 0 \\
\hline Amsinckia lycopsoides & $0.09 \pm 0.04$ & $0.02 \pm 0.02$ \\
\hline Artemisia tridentata & $0.35 \pm 0.12$ & $30 \pm 1.12$ \\
\hline Bromus tectorum & $1.53 \pm 0.1$ & $1.06 \pm 0.1$ \\
\hline Centaurea diffusa & $0.05 \pm 0.03$ & 0 \\
\hline Chenopodium leptophyllum & $0.16 \pm 0.05$ & 0 \\
\hline Chrysothamnus viscidiflorus & $0.02 \pm 0.02$ & $0.1 \pm 0.1$ \\
\hline Descurainia pinnata & $0.07 \pm 0.03$ & 0 \\
\hline Elymus wawawaiensis & $1.84 \pm 0.39$ & $0.3 \pm 0.07$ \\
\hline Ericameria nauseosa & $1.09 \pm 0.1$ & $0.19 \pm 0.11$ \\
\hline Erodium cicutarium & $0.02 \pm 0.02$ & $0.02 \pm 0.02$ \\
\hline Machaeranthera canescens & $1.11 \pm 0.14$ & $0.05 \pm 0.03$ \\
\hline Melilotus officinalis & $1.56 \pm 0.37$ & 0 \\
\hline Poa ampla & 0.03 & 0.19 \\
\hline Poa bulbosa & 0 & $0.12 \pm 0.04$ \\
\hline Poa secunda & $0.07 \pm 0.03$ & $0.16 \pm 0.05$ \\
\hline Salsola kali & $19.5 \pm 0.86$ & 0 \\
\hline Sisymbrium altissimum & $2.1 \pm 0.23$ & $0.31 \pm 0.07$ \\
\hline Tragopogon dubius & $0.03 \pm 0.02$ & 0 \\
\hline Vulpia microstachys & $0.03 \pm 0.02$ & $0.03 \pm 0.02$ \\
\hline Grass & $3.51 \pm 0.42$ & $1.86 \pm 0.18^{*}$ \\
\hline Shrubs & $1.46 \pm 0.16$ & $30.3 \pm 1.13^{*}$ \\
\hline Forbs & $24.7 \pm 0.97$ & $0.4 \pm 0.1^{*}$ \\
\hline Soil cryptogams & 0 & $28.3 \pm 1.63^{*}$ \\
\hline Woody litter & $4.06 \pm 0.35$ & $3.28 \pm 0.25$ \\
\hline Herbaceous Litter & $3.89 \pm 0.33$ & $42.1 \pm 1.64 *$ \\
\hline Total litter & $7.95 \pm 0.52$ & $45.3 \pm 1.7^{*}$ \\
\hline Soil & $76.6 \pm 1.09$ & $25.5 \pm 1.22 *$ \\
\hline Rock & 15 & $12.1 \pm 0.44^{*}$ \\
\hline Bare ground & $76.6 \pm 1.09$ & $53.8 \pm 2.06^{*}$ \\
\hline
\end{tabular}


in the burned section compared with the unburned section. The bunchgrass (Elymus wawawaiensis) remains sparse except in the northeast corner of the burned half of the barrier and along the perimeter of the barrier. Cheatgrass (Bromus tectorum) cover is very low, but was found in association with $A$. tridentata and in other disturbed areas. Wind-blown tumbleweeds remain trapped along the edges of the barrier and are most common on the south, west, and east edges.

Comparisons of cover types were made using midpoints of cover classes to compute means. The spatial distribution of percent cover, as shown in Figure 3.5, was quite variable. The mean cover classes for the formerly irrigated (north) portion of the silt-loam plots prior to the burn is shown in Figure 4.6. Grass cover was significant greater than zero, but significantly less than shrub cover and other classes. Soil cryptogam cover was the same as soil cover. Percent cover was estimated for shrubs, tumbleweed, grasses, forbs, and litter. These cover estimates were summed and in some cases exceeded $100 \%$.

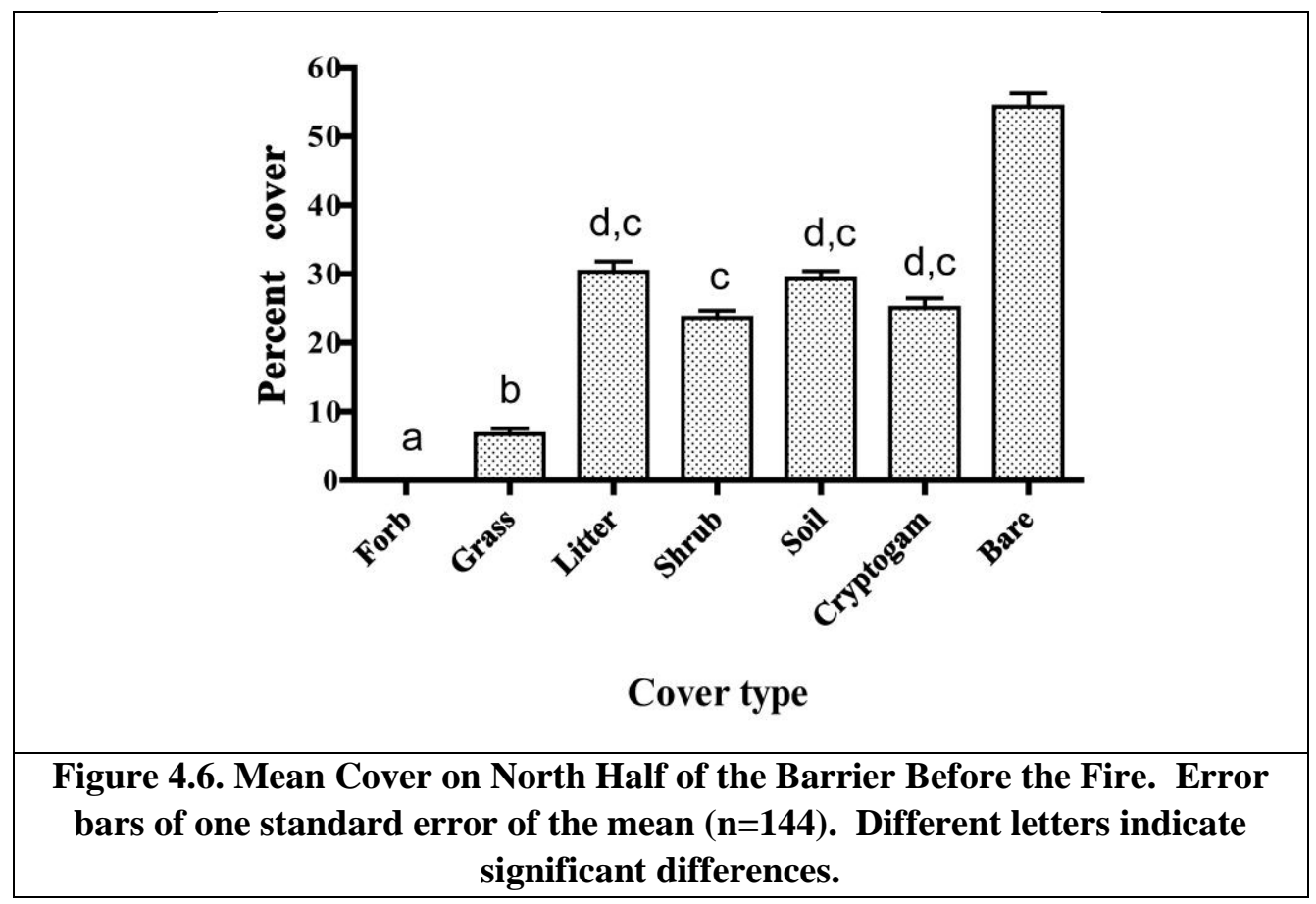

The mean cover classes for the south portion of the silt-loam plots prior to the burn is shown in Figure 4.7. Gorund cover was similar to the north before the fire. Grass cover was also significant greater than zero, and significantly less than shrub cover and other classes. Soil cryptogam cover was the same as soil cover. Percent cover was estimated for shrubs, tumbleweed, grasses, forbs, and litter. These cover estimates were summed and in some cases exceeded $100 \%$. 


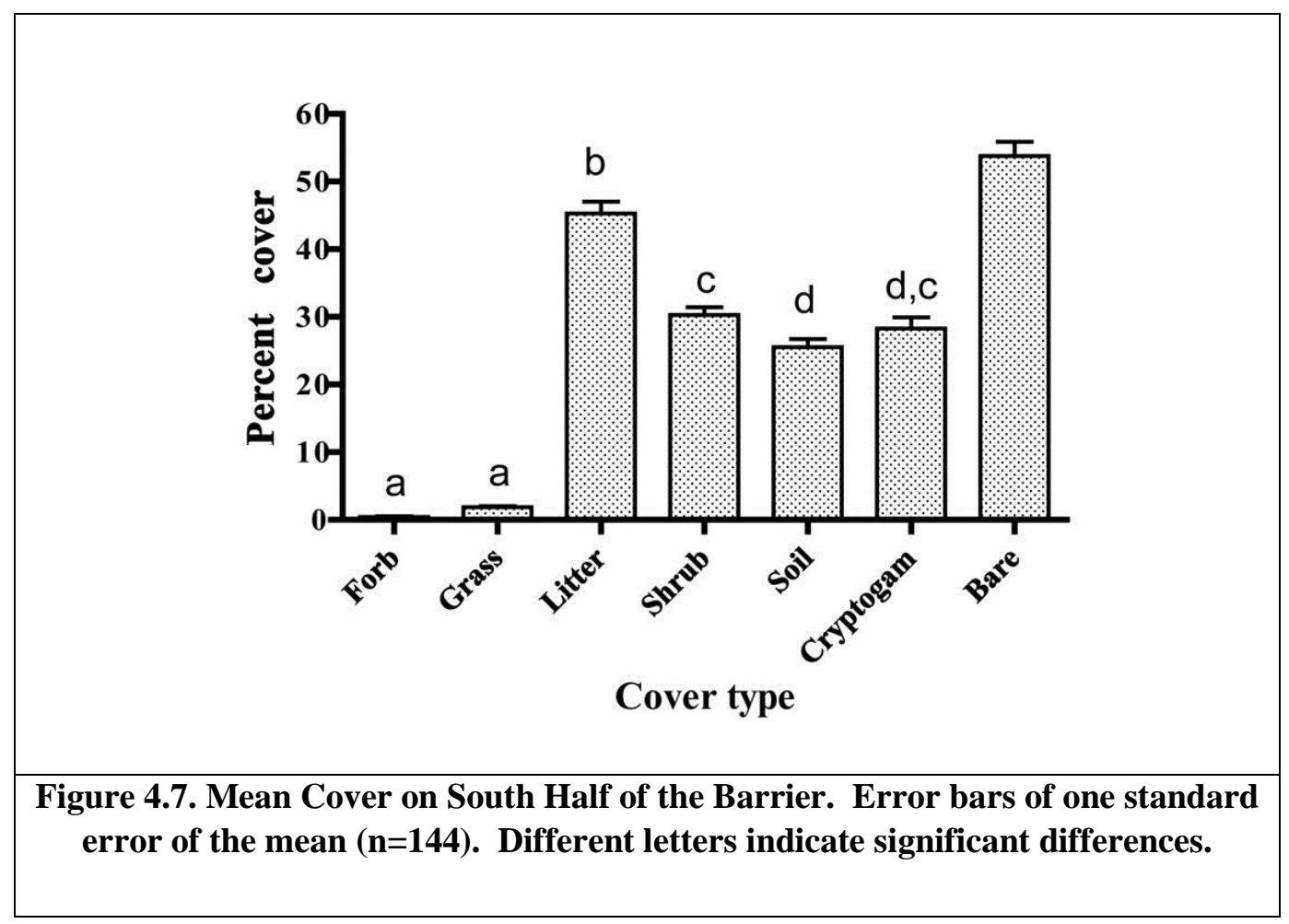

Cover on the north and west side slopes was relatively uniform, thus data were combined (Figure 4.8Error! Reference source not found.). Rock cover was much greater than cover of other classes while cover of shrubs and grasses (mostly bunchgrasses) were similar.

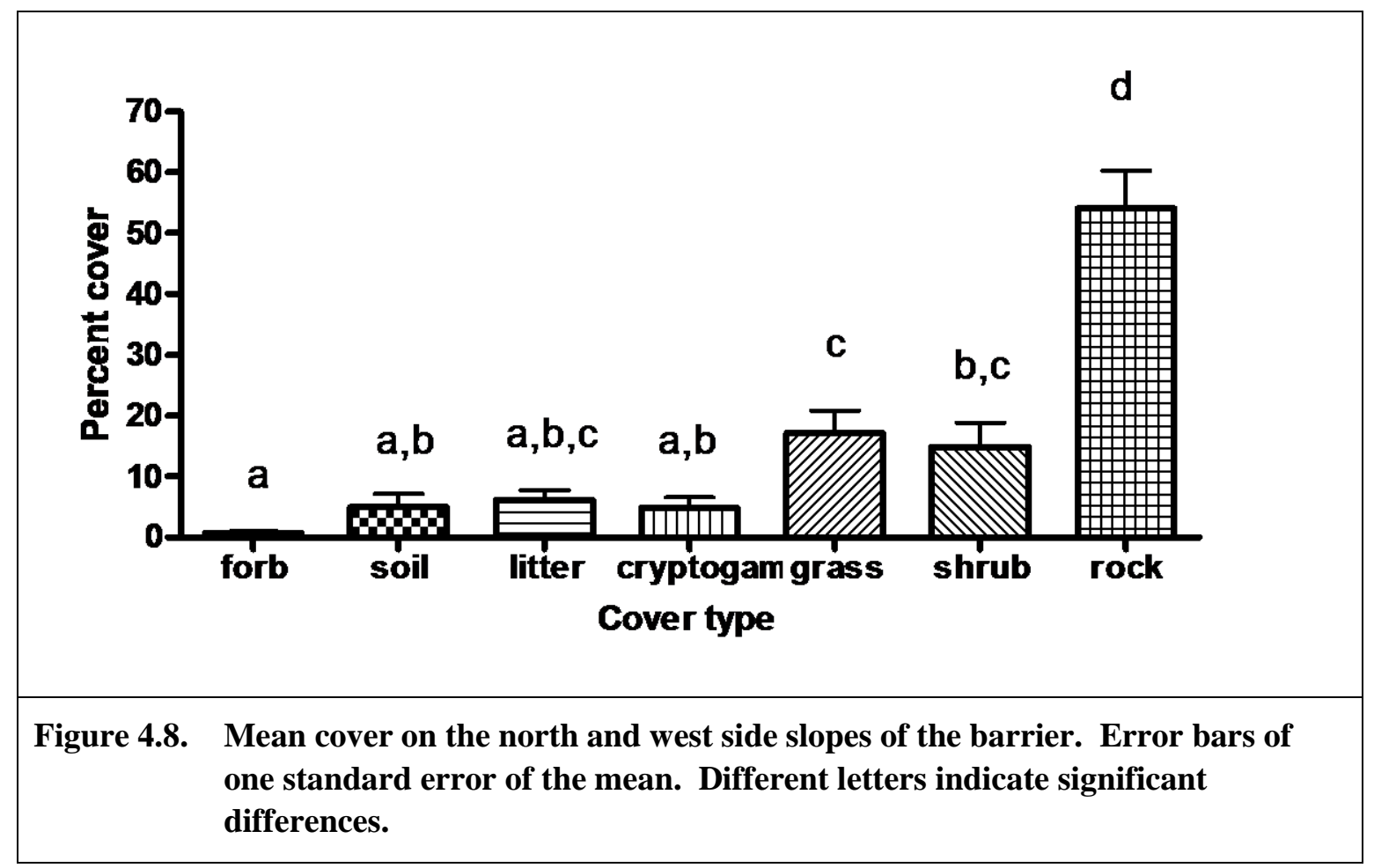




\subsubsection{Shrub Density}

Artemisia tridentata density was significantly lower after the burn than in the unburned area (Table 4.10). Ericameria nauseosa established on the north side in significant, but low numbers after the fire. Shrub density also varied by size/age class (Table 4.11). Ninety-six percent were old on the barrier unburned half. This indicates that the shrubs, while reproducing, are reproducing at very low rates. Most sagebrush shrubs had only a few flowering stems. There were no new seedlings observed in the unburned half of the barrier while the two earlier observed two cohorts have aged and are now at least 6 years old and midsized. The shrubs in the unburned half of the barrier likely will die faster than they are recruited until the density of large shrubs is closer to that in natural areas. When density has been sufficiently reduced then it is likely that the A. tridentata population will achieve a more natural size/age distribution. After the burn a significant number of shrubs germinated from the seed bank and/or from seed that arrived at the site. Artemisia tridentata seed is not wind-borne and likely came from the seed bank. Eighty-eight percent of the new shrubs on the burned barrier surface were E. nauseosa. It is possible that these new recruits arrived from nearby plants that released wind-borne seed after the fire. While there are few $E$. nauseosa plants in the adjacent unburned barrier surface there are numerous shrubs on the adjacent side slopes that can be the source of the new recruits on the burned surface.

Table 4.10. Mean shrub density \pm 1 standard error of the mean (plants $\mathbf{m}^{-2}$ ).

\begin{tabular}{|l|l|l|}
\hline Species & Burned & Unburned \\
\hline Artemisia tridentata & $0.0146 \pm 0.00539 \mathrm{a}$ & $0.77 \pm 0.0121 \mathrm{~b}$ \\
\hline Ericameria nauseosa & $0.113 \pm 0.0127 \mathrm{a}$ & $0.00386 \pm 0.00202 \mathrm{~b}$ \\
\hline Chrysothamnus viscidiflorus & 0 & $0.0107 \pm 0.00609$ \\
\hline
\end{tabular}

Table 4.11. Mean size/age density $\left(\right.$ plants $\left.\mathrm{m}^{-2}\right) \pm 1$ standard error of the mean of $A$. tridentata.

\begin{tabular}{|l|l|l|}
\hline Size/age class & Burned & Unburned \\
\hline Large/old & 0 & $0.743 \pm 0.0104$ \\
\hline Mid-size & 0 & $0.027 \pm 0.00712$ \\
\hline Small/young & $0.0146 \pm 0.00539$ & 0 \\
\hline
\end{tabular}




\subsection{Summary}

The prototype barrier continues to show high cover of native plants on the unburned half of the barrier surface 15 years after the initial restoration effort. The cover of grasses on the surface was greater on the burned portion compared with the unburned portion. This effect is, in part, likely a consequence of initial conditions when higher water encouraged bunchgrasses. It is likely that grass cover will increase in the burned portion without significant competition. It is likely that grass cover will continue to decrease in the unburned half while A. tridentata cover remains high. Shrub cover (mostly A. tridentata) has remained the same on the unburned portions of the barrier surface from 1997 to 2009 and now very low on the burned half. Forbs, mostly $S$. kali) were more common on the burned portion.

The species richness of the surface increased to 24 after the fire and these were all found on the burned half of the surface. The increase is nearly all annuals and biennials that do well after fire and other disturbances. This component of the species mix likely will decrease as perennials or other disclimax annual species such as B. tectorum re-establish. Artemisia tridentata remains the most common plant on the unburned half of the surface and comprises almost a monoculture. There is some risk in this condition. If the shrubs were to die in a pathological event as may be happening with significant insect gall infestation, or in a fire as tested, then it can be concluded, based on the fire study, that other vegetation will not immediately occupy new available space on the surface and it is possible that the function of the barrier could be compromised. With few plants it is possible that water may become available for drainage. Continuing investigation of the effects of loss of the shrubs will be useful to determine the resiliency of the surface to prevent drainage. Vegetation would always return to the surface after a significant disturbance or die-off, but the amount of time needed may increase the threat to the function of the barrier.

Shrubs along the perimeter of the barrier appear to be more productive than shrubs on the interior of the barrier. The observed differences in cover (Figure 1.6) along the eastern, southern, and western edges of the barrier may be caused by a combination of physiological and hydrological factors. A difference in cover could be the result of reduced competition, because plants along the barrier's edges receive competition from only three sides compared to those on the interior, which receive competition from plants from all four sides. There is more water along the edges of the barrier and this likely is associated with larger size and cover of shrubs along the edges. Water content data obtained at the bottom of the silt-loam layer by the horizontal neutron measurements have shown an annual increase in water content near the edge of this zone in recent years (DOE/RL-99-11). With the absence of plants beyond the siltloam edge, this water would be available entirely to plants at the perimeter, providing more water for uptake and possibly extending the period of water availability, particularly on the western edge, which has a gravel side slope. It is known that the gravel side slopes produce drainage all year, in contrast to the eastern riprap slope, which, because of advective air flow, does not generate any drainage in the summer. This observation supports the presence of more available water in the silt-loam-gravel transition zone than in the silt-loam-riprap zone at the eastern side. This would suggest more available water along the western edge and thus larger plants and higher cover along that boundary. The western and northern side slopes of the barrier showed less vegetated cover than the barrier surface, but has a large component of $E$. nauseosa. It is suspected the significant and relatively high density of E. nauseosa on the burned half of the surface is because there is a lot of wind-borne seed from the side slope populations. 
This page intentionally left blank. 


\subsection{Animal Intrusion}

This section discusses the methodology and the results of examining animal intrusion on the Prototype Hanford Barrier.

\subsection{Methodology}

The barrier surface was examined for evidence of use and intrusion (burrowing) by insects and small mammals on September 13, 2009. This was done by carefully inspecting 288 of 300 sample squares on the surface. The row between the burned and unburned portions of the surface was not assessed. Indications of animal use included direct observation and presence of droppings, tracks, nests, burrows, or holes, and gall formation on A. tridentata. Hole size was classed as large ( $>\sim 2 \mathrm{~cm}$ diameter) or small. Holes in each class were counted in each plot. The degree of gall formation and amount of feces were classed into high and low groups. A high degree of gall formation was noted when any shrub had numerous (> 50) galls. A large number of rabbit feces was noted when feces were concentrated in patches while a plot with few feces that were widely distributed was classed as low. The Van der Waerden non-parametric test was used when data were not normally distributed to compare responses in the burned and unburned treatments. The relationship between rabbit feces and cover of Elymus wawawaiensis was determined by relating the \% of plots in each of 25 rows that had feces with mean $\%$ cover of E. wawawaiensis in each row. Each of the 25 rows has 12 plots.

\subsection{Results}

Animal holes were significantly ( $p<0.0001)$ more prevalent on the unburned half $(0.0414 \pm 0.00737$ holes $\left.\mathrm{m}^{-2}\right)$ than on the burned half $\left(0.0054 \pm 0.002\right.$ holes $\left.\mathrm{m}^{-2}\right)$. Of 61 holes found in all the plots 31 were large and 30 were small. Of 21 holes dug by rodents, 20 were large. Of 38 holes dug by insects, 9 $(23.7 \%)$ were large. There were no significant $(\mathrm{p}>0.05)$ linear relationships between location $(\mathrm{X}, \mathrm{Y})$ and hole density.

Cottontail rabbit (Sylvilagus nuttallii) use, indicated by the $\%$ of plots with feces in each of 25 rows, was positively correlated with \% cover of $E$. wawawaiensis (\%plots with feces $=27.7+5.9 *$ mean $\%$ elwa cover; $\mathrm{p}=0.0077)$. Most $E$. wawawaiensis plants had experienced herbivory and we assume by rabbits. Coyote feces were noted in two locations on the surface.

Galls, most likely attributed to a fly or wasp, were found infesting a number of $A$. tridentata plants. Some of the A. tridentata were heavily infested damaging the shrub. Of 144 plots in the unburned half of the barrier $102(71 \%)$ had infested shrubs and $19 \%$ of the plots had heavily infested shrubs. This infestation will likely reduce the population density of $A$. tridentata in future years. Only one plot in the burned half of the surface had galls on an $A$. tridentata seedling.

\subsection{Summary}

The barrier surface shows continuing use by animals. The fire apparently reduced animal burrowing. The holes can potentially be a source of variation in soil water patterns, but they are small and make up a very small portion of the surface. There is little or no use of the surface by large burrowing animals such as badgers yet. Use of E. wawawaiensis by rabbits is substantial. Herbivory was significant and potentially can lead to a reduction in E. wawawaiensis especially if seed production is reduced. There 
were seeds of E. wawawaiensis in the seed bank, but it is not known if their number would be greater without herbivory. Insect galls on A. tridentata were significant and damaged shrubs with heavy infestation. This infestation likely will continue to reduce A. tridentata populations. Further work documenting belowground effects by insects and mammals would provide useful information on channel development and other soil pedogenic processes. 


\subsection{References}

42 USC 9601. Comprehensive Environmental Response, Compensation, and Liability Act of 1980, et seq. Daubenmire R. 1959. “A Canopy-Coverage Method of Vegetational Analysis.” Northwest Science, 33:43-64.

Fluor Hanford, Inc. 2003. 200-BP-1 Prototype Hanford Barrier Annual Monitoring Report for Fiscal Year 2002. CP-14873, Rev. 0, Richland, WA.

Fayer MJ and GW Gee. 2006. Multiple-Year Water Balance of Soil Covers in a Semiarid Setting. J. Environ. Qual. 35:366-377.

Freeman HD, RA Romine and AH Zacher. 1994. Hanford Permanent Isolation barrier Program: Asphalt Technology Data and Status Report- FY 1994. PNL-10194, Pacific Northwest National Laboratory, Richland, WA.

Hoitink DJ, KW Burk, JV Ramsdell, Jr, and WJ Shaw. 2005. Hanford Site Climatological Summary 2004 with Historical Data . PNNL-15160, Pacific Northwest National Laboratory, Richland, WA.

Link, S. O., B. D. Ryan, J. L. Downs, L. L. Cadwell, J. Soll, M. A. Hawke, and J. Ponzetti. 2000. Lichens and mosses on shrub-steppe soils in southeastern Washington. Northwest Science 74:50-56.

National Research Council (NRC). 2007. Assessment of the performance of engineered waste containment barriers, Committee to Assess the Performance of Engineered Barriers, Washington, D.C. Pacific Northwest Laboratory (PNL). 1995. Procedures for Routine Maintenance and Calibration of Dosing Siphons at the Prototype Surface Barrier. PNL-PSB-4.0, Richland, WA.

Pacific Northwest National Laboratory (PNNL). 1995. Procedure for Measuring Soil Moisture Using the Neutron Probe in the Neutron Probe Access Tube Vertical and Horizontal Arrays. PNNL-PSB-10.0, Richland, WA.

Pacific Northwest National Laboratory (PNNL). 1999. Measuring Soil Water Content With the Moisture Point Time Domain Reflectometry System. PNL-PSB-7.0, Richland, WA.

Pacific Northwest National Laboratory (PNNL). 2004. Hanford Site Climatological Data Summary 2003 with Historical Data. PNNL-14616, Richland, WA.

Steele, R. B. D., and J. H. Torrie. 1960. Principals and Procedures of Statistics. McGraw-Hill, New York U.S. Department of Energy-Richland Operations (DOE-RL). 1999. 200-BP-1 Prototype Barrier Treatability Test Report, Rev. 0, DOE-RL-99-11, Richland, WA. 


\section{Distribution}

(Issued on Electronically)

No. of

Copies

ONSITE

3 U.S. Department of Energy-Richland Operations

K.D. Leary

J.G Morse

DOE Public Reading Room

A6-38

A5-11

$\mathrm{H} 2-53$

1 Fluor Federal Services

R. Khaleel

R3-50

7 CH2M-Hill Plateau Remediation

Company, Inc.

G.T. Berlin

H8-15

M.W. Benecke

R3-60

B.H. Ford

R3-19

D.L. Fort
No. of

Copies

\section{ONSITE}

J.D. Hoover

H8-15

S.W. Petersen R6-50

C.D. Wittreich H8-15

9 Pacific Northwest National Laboratory

R.E. Clayton K6-75

K.E. Draper K6-66

M.J. Fayer K9-33

A.L Ward K9-33

Information Release (5)

Distr. 1 